
acta

>

-

>

-

D.

$>$
>

-

>

>

-

- 
$\operatorname{acta}$

$>$

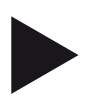

$>$

$>$

$>$

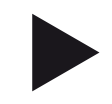

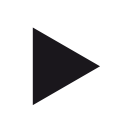

$>$

$>$

\section{Acta FF ZČU}

Fakulta filozofické

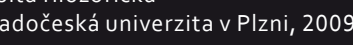

Prof. RNDr. Ivo Budil, Ph.D., DSc., editor, 2009

Registrace MKČR E 16521

Datum vydani: 18. 12. 200

ISSN 1802-0364

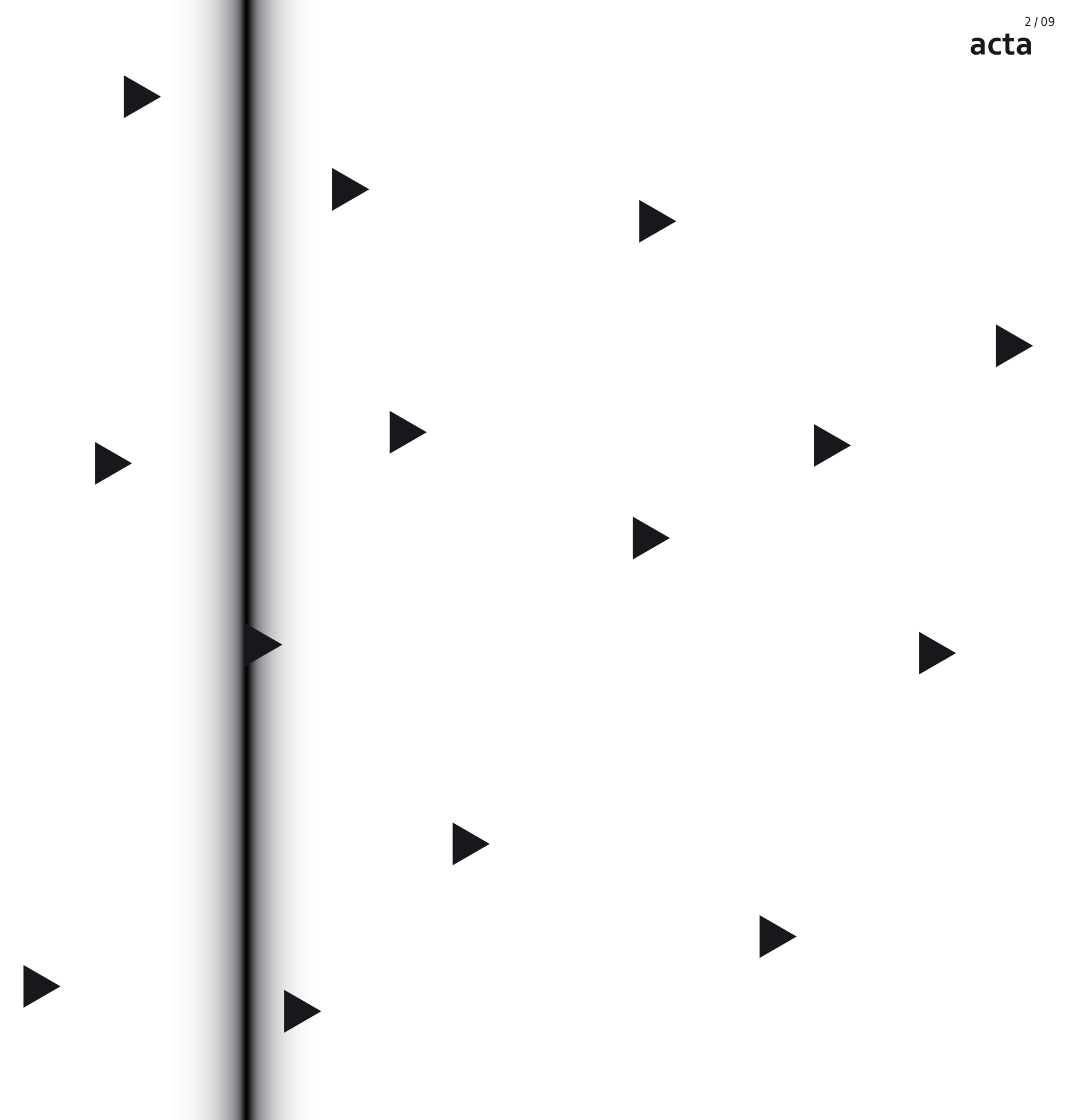




\section{obsah}

Prof. RNDr. Ivo Budil, Ph.D., DSc.

\section{PŘíSPĚVKY}

Originál či napodobenina?

"Syropalestinské importy" v Egyptě doby Staré říše Mgr. Lucie Jirásková

Když není Cesta vykonávána:

oncept přerušení daotongu v díle Yulgoka Yi I $(1536$ - 1584)

Mgr. Vladimír Glomb

na na C. S. Lewise

doc. Pavel Hošek, Th.D.

Chesterton jako prorok vědy?

PhDr. Jan Lukavec, Ph.D.

$54 \quad$ Asyrský korunní princ

Mgr. Kateřina Šašková, Th.D.

74 Prvorozenectví v knize Genesis prizmatem sociální a kulturní antropologie Barbora Polifková (a)

Bc. Daniel Rafael Moulis

Detektory kovư jako nástroje revize nálezů minci: Kelčský připad islámského stříbra

PhDr. Vlastimil Novák, Dr.

Postmoderni státy jako nositelé a zprostředkovatelé kantovské etiky mezinárodních vztazích

doc. PhDr. Ladislav Cabada, Ph.D.

doc. PhDr. Šárka Cabadová Waisová, Ph.D.

ROZHOVOR

Rozhovor s doc. PhDr. Petrem Charvátem, DrSc.

PhDr. Lukáš Pecha, Ph.D.

RECENZE

134 Zakladatelia Západu, koniec dejín a posledný človek

Mgr. Petra Burzová

144 The Cambridge Companion to the Scottish Enlightenment Mgr. Svatava Heinlová 
úvod 
Prof. RNDr. Ivo Budil, Ph.D., DSC.

\section{Úvodní slovo}

Není náhoda, že nové čislo Act Fakulty filozofické Západočeské univerzity v Plzni, které čtenár dostává do rukou, obsahuje rozhovor právěs docentem Petrem Charvátem, pracovnikem Katedry antropologických a historických věd FF ZČU a předním českým archeologem, antropologem a orientalistou, který nedávno oslavil významné životní jubileum. Témata, kterými se pan docent badatelsky zabývá, nám prípomínají nejen pomijivost věc pozemských, ale také malichernost a nicotnost různých velkých ",témat" , "diskuzi", „sporü" a "pohoršeni", kterým v zaslepenosti přtomným okamžikem přikládáme takovou váhu. Do cent Petr Charvát se věnuje mimo jiné starověkým civilizacím, které dosáhly velikosti nikoliv pouze proto, že po sobě zanechaly monumentální památky, ale především z dưvodu, že dokázaly poprvé uchopit, formulovat a položit zásadni otázky po smyslu lidské existence. Otázky, při jejichž řešení jsme v žádném prípadě nepokročili, ale které - na rozdíl od našich predchůdců - naopak marginalizujeme a vytěsňujeme z našich životủ. Acta Fakulty filozofické Západočeské univerzity v Plzni tentokrát nabizejí exkurz do starého Egypta, Palestiny, Sýrie, světa islámu, Jeruzaléma či až na Dálný východ. Doufáme, že v něm čtenář nalezne nejen ponaučení, ale také úlevu od občasné bezútěšnosti dnešnich dní.

Podle jednoho čínského přisloví když malí muži začnou vrhat velké stíny, znamená to, že se bliží soumrak. Co jiného nás může napadnout při pohledu na patafyzický chaos zachvacujicí za vydatné pomoci zlomyslných médií současný akademický prostor? Znamená to, že poslední asyl, naděje, že v dnešním světě ještě existuje výspa zdravého rozumu a morálnich zásad, padla? Ujal se snad vlády Otec Ubu? Kde je osobnost, která by tak 
jako kdysi (ve zcela jiné souvislosti) zvolala s Voltairem: "Zničte hanebnost!” Dobrá zpráva je, že takový muž existoval. Špatná, že zemřel již v roce 1936. Jmenoval se Gilbert Keith Chesterton a byl to významný anglický spisovatel. Katedra antropologických a historických věd FF ZČU mu ve spolupráci s doktorem Janem Lukavcem, autorem zajímavé knihy o Chestertonovi, věnovala na jaře 2009 jednodenní odborné symposium. Dva z přednesených přispěvkủ byly zařazeny do Act Fakulty filozofické Západočeské univerzity v Plzni jako samostatné studie.

Přejeme čtenárưm Act Fakulty filozofické Západočeské univerzity v Plzni poklidné soustředěni pri četbě našeho periodika a doufáme, že nám i nadále zachovají svoji věrnost. př́spěvky

Lucie Jirásková Vladimír Glomb

Pavel Hošek

Jan Lukavec

Kateřina Šašková

Barbora Polifková

Daniel Rafael Moulis

Vlastimil Novák

Ladislav Cabada

Šárka Cabadová Waisová 
Lucie Jirásková

\section{Originál či napodobenina? "Syropalestinské importy" $v$ Egyptě doby Staré ř́še}

\section{Abstract}

The vessels of Syria-Palestinian form acquired from the Archaic Period or Old Kingdom contexts had been considered as genuine imports brought to Egypt from Asia by the means of long-distance trade. However, the analysis performed by Naomi Porat on the "foreign" pottery found within the tomb U-j at the Predynastic U-cemetery at Abydos showed that most of the vessels had probably been made in Egypt from the Nile silt. New publications from the recent research at Saqqara and Abusir have raised doubts concerning the origin of com bed ware uncovered in the tombs of some Fifth and Sixth Dynasty official. As the chemical analyses cannot be always relied on, different approaches to the problem should be found. The aim of the paper is represented by the focus on the social background of the people who had the "foreign" vessels deposited in their tombs, general political development and a particular feature of the combed ware - their volume.

Po většinu 20. století nebylo o pưvodu nádob syropalestinských forem objevených jednak v archaických, jednak ve staroříšských hrobkách pochybováno a otázka oblasti, kde byly skutečně vyrobeny, byla nastolena až s novými nálezy. I když je to v egyptských podmínkách často nelehké, jsou nově objevené kusy z větší části podrobovány chemickým a petrografickým analýzám, které maji určit materiál, z něhož byly vyrobeny a přibližně specifikovat oblast, z niž daný materiál pocházel. Průlom v tomto ohledu představují především 
nálezy německé expedice, která od 70. let systematicky odkrývá elitní predynastické (U) a královské archaické pohřebiště (B) v Abydu. Na pohřebišti U bylo v rámci tohoto dlou hodobého výzkumu již odkryto přibližně 500 nádob syropalestinských forem, přičemž 350 z nich pochází pouze z hrobky U-j. ${ }^{1}$ Na první pohled se svým tvarem výrazně liši od tradiční egyptské keramiky své doby, a tak byly považovány za doklad poměrně významných kontaktů mezi touto oblastí a údolím Nilu v době, kdy se zde postupně formoval nejstarší státní celek (WILKINSON, Toby A. H., 1999, s. 151). S nálezem se však vzhledem k množství nádob vzedmula vlna pochybností, jedná-li se o skutečné importy a nebo jen jejich napodobeniny vyrobené v Egyptě z nilské hlíny. ${ }^{2}$ Výsledky jednotlivých rozborư ukázaly, jak nejisté mohou analýzy být a k jak rưznorodým závěrům mohou vést. Z výsledků srovnávání archeologických paralel a chemických analýz (neutronová aktivační analýza, rentgenová analýza a petrografická analýza), které prezentoval U. Hartung, vyplývá, že nádoby nalezené na pohřebišti U v Abydu pocházely z několika odlišných regionů palestinské oblasti (HARTUNG, Ulrich, 2002, s. 437 - 438). Oproti tomu petrografický rozbor nádob z U-j provedený N. Porat a Y. Gorenem ukázal, že ne všechny nádoby je možné považovat za importy a většina byla vyrobena z egyptských materiálů nejpravděpodobněji v oblasti Wádí Kena, vzdáleném od Abydu 35 - 50 km (PORAT, Naomi a Yuval GOREN, 2002, s. $263-266$ ).

V nedávné době byla stejná otázka nastolena i v prípadě nádob syropalestin ských forem pocházejících z pozdějšího kontextu Staré ríše. Po dlouhou dobu byly bez výjimky považovány za pravé, v určitých případech snad znovu použité (např. nádoba odkrytá v Matmáru), prípadně v Egyptě nově zapečetěné (jedna $z$ amfor uložených v hrobce Ptahšepsese Impyho v Gíze). Nálezy české expedice v jižním Abúsíru, australské na Tetiho pohřebišti v Sakkáře a polské na pohřebišti západně od Džoserova kom plexu - taktéž v severní Sakkáře - ukázaly, že zřejmě existovaly výjimky a dosavadn závěry je třeba přehodnotit. $V$ jižním Abúsíru byly prozkoumány dvě hrobky, které $\checkmark$ rámci pohřebni výbavy obsahovaly několik nádob neegyptské formy. Ve starší z hrobek pocházející z počátku 5 . dynastie, postavené pro úředníka Kaiapera byly objeveny fragmenty dvou džbánů s jedním uchem tenkého tvrdého střepu, zdobené "hřebenovou" technikou (tenkými rýhami vzniklými před vypálením hlíny „česáním” nádoby předmětem podobným jemnému hřebenu - tzv. combed ware). $V$ tomto prípadě se podle $M$. Bárty s největší pravděpodobností jedná o skutečné "kovové zboži” (tzv. metallic ware),

1) Dalších 50, 30 a 6 tvaremneegyptskýchnádobobsahovaly hrobkyU-k, U-aaU-o(HARTUNG, Ulrich, 2002, s. 437).

2) Sám Wilkinson upozorňuje na skutečnost, že v době, kdy egyptské hrobky zaplavily „syropalestinské importy”, došlo v Syropalestině samotné k prudkému omezeníegyptské prítomnosti (WILKINSON, Toby A. H., 1999, s. 151). typické pro syropalestinskou keramiku především rané doby bronzové III (BÁRTA, Miroslav et al., 2001, s. 185). Druhá, mladší hrobka patřila rodině vezíra Kara, přičemž nádoby zde byly uloženy až v druhé polovině 6 . dynastie pro potřebu posmrtného života jeho dvou synů, Kara juniora a Senedžemiba (BÁRTA, Miroslav, 2009, s. 73 - 94). V tomto př́padě se jedná o amfory rovněž zdobené "hřebenovou" technikou, ovšem silného střepu, netypického pro luxusní syropalestinské zboží. Jedna z nádob dokonce spojuje dva prvky objevující se tradičně zvlášt na dvou různých typech nádob. Jedná se o vystouplý pásek oddělujići hrdlo od těla nádoby, který se neobjevoval u dvouuchých amfor (BÁRTA, Miroslav v v tisku). Většina nádob byla současně objevena zapečetěná zátkami vyrobenými z nilského bahna, které nesly bílé otisky pečeti s egyptským textem. Celý soubor byl na základě těchto skutečností označen jako napodobeniny vyrobené z nilského bahna. K závěru, že se jedná o imitaci došla i T. Rzeuska, která zkoumala keramiku z hrobek nekropole západně od Džoserova komplexu v Sakkáře pocházejíci ze 6. dynastie. Jedná se o amforu, jež původně náležela k šachtě Nianchnefertema (RZEUSKA Teodozja, 2004, s. 134). Další tři objevené nádoby podle jejích pưvodních závěrů představuji syropalestinské originály (RZEUSKA, Teodozja, 2002, s. 154; 2003, s. 146) ovšem pozdější analýzy ukázaly, že se i v tomto prípadě nejspíše jedná o výrobky egyptských dílen z místního materiálu (RZEUSKA, Teodozja, konzultace). Další z dvouuchých amfor vyrobených z nilského bahna podle vzoru tradičního syropalestinského zboži byla odkryta v hrobce Kaiemheseta v Sakkáře (McFARLANE, Anne, 2003, s. 45).

Jelikož metoda porovnávání či chemických analýz nemusí být vždy spolehlivá, je užitečné se na nádoby podívat $v$ jiných souvislostech a hledat nové možnosti interpretace. $V$ rámci sídlištní archeologie bylo dosud v Egyptě v kontextu Staré říše nalezeno pouze několikstřepů, které naznačuji přitomnost importů ve městech (WODZIŃSKA, Anna, 2007, s. 311 - 313; FORSTNER-MÜLLER, Irene a Dietrich RAUE, 2008). Většina nálezư ale pochází ze soukromých hrobek, kde tvořily významnou součást pohřební výbavy hodnostářu doby 4. - 6. dynastie. Jednotlivé hrobky, jejich umístění a výzdoba vypovídají o postavení jejich majitelů a o proměnách poměrů v průběhu vývoje Staré ŕí̌̌e. $\checkmark$ kontextu 4. dynastie byly importy nalezeny predevším v Gíze (REISNER, Georg A., 1942, s. 411, 437, 450, 463, 465, 468, 470, 474, 478, 487, 490, 494, 508; REISNER, Georg A. a William S. SMITH, 1955, s. $64-65,76$; JUNKER, Hermann, 1929, s. 234, 248; KORMYSHEVA, Eleonora, 2001, s. 80), jedna v Dahšúru (ALEXANIAN, Nicole, 1999, s. 108 - 110), jedna v Mejdúmu (PETRIE, William M. F. 1910: pl. XXIV/4) a jedna v Matmáru (BRUNTON, Guy, 1948, s. 29). Analýzy části džbánu, poměrně nedávno odkryté v Dahšúrské hrobce prince Nečeraperefa, představily nádobu jako produkt vyrobený v severní

3) Raná doba bronzová llI je považována za přibližně současnou se Starou řǐši. Ač se ná zory na její konec liší, je pravděpodobné, že skončila s koncem 5. dynastie, kdy začala raná doba bronzová IV (de MIROSCHEDJI, Pierre, 2002, s. 47). 
Palestině či na syrském pobřeži. Kromě Matmáru, kde byla uložena zřejmě již sekundárně použitá nádoba, nacházely se ostatní v hrobkách poměrně vysokých hodnostářư či členů nejužší královské rodiny. Jejich tituly $z \boldsymbol{A}$ či zAt nswt je řadí př́mo do královské rodiny. Oproti této skutečnosti stojí situace $v$ následující 5 . dynastii. Ačkoli Gíza v této době již začala představovat druhořadé pohřebiště, většina „importovaných" nádob byla odkryta právě zde (JUNKER, Hermann, 1929, Abb. 14.11; REISNER, Georg A 1942, s. 516; REISNER, Georg A. a William S. SMITH, 1955, s. 74, 76; HASSAN, Selim, 1936, s. 145). Dva již výše zmíněné džbány odkryly výzkumy v Abúsíru a další dvě amfory v Sakkáře - hrobky Kaiemheseta a Kara (HAWASS, Zahi, 2004, s. 317). V prípadě majitelů tohoto souboru se jedná o osoby různého postavení, které nepatřily ke královské rodině. Doba 5. dynastie představovala zlom v organizaci státních záležitostí, kdy se administrativa postupně přesunula z rukou králových přibuzných do rukou nekrálovské byrokracie (HELCK, Wolfgang, 1954, s. 132). Mezi těmito novými úředníky vyčnívá pouze postava Senedžemiba-Intiho, který nesl titul vezíra a společně s ním i pět nejvyšších správních titulů ( „, dohližitel nad 6 velkými soudními dvory”, „, dohližitel nad písaři královských dokumentư”, „, dohližitel nad všemi královskými pracemi”, „, dohližitel nad oběma sýpkami" a "dohližitel nad oběma pokladnicemi"), které podle N. Strudwicka za svým jménem tradičně nechávali psát nejvyšši úředníci staroříšské administrativy této doby, jimž byl udělován titul vezíra (STRUDWICK, Nigel, 1985). Senedžemib-Inti byl také jediným př́islušníkem nobility, označované jako iry-pat. Co se týče honorifických titulư, zaostávají za ním další známí majitelé „importư”, z větší části nesoucí titul iry-xt nswt. Kaiaper a Sešemnefer I., jinak úředníci střední vrstvy, nesli titu dohližitel královských praci", sice podobný jednomu z nejvyšších titulů, ale v jejich př́ipadě zřejmě odlišný druh (STRUDWICK, Nigel, 1985, s. 249). Na rozdíl od Kaiapera, který sloužil především v královském vojsku a pevnostech, představoval Sešemnefer I. úředníka zabývajíciho se službou v královském paláci a kněžskými povinnostmi. K vojenským funkcím Kaiapera měl blízko Nefernisut, jenž byl opět spojen i s královským palácem. Ke stejné vrstvě patřil Kaiemheset, na základě svých titulů zodpovědný především za královské stavební práce. Poslední z mužů, jejichž (alespoň některé) tituly byly publikovány, Kar, je znám pouze jako „královský lékař”" (titul a jméno jsou inkoustem zapsány prímo na zkoumané amfoře).

Prameny k počátku 5. dynastie ukazuji, že zřejmě dále přetrvávala mírová povaha vztahů Egypta a Syropalestinské oblasti, ovšem k jejímu konci začalo docházet ke zhoršování situace. Objevuje se více zmínek o bojích s Asijci a Džedkare začíná s bu dováním opevnění nazývaného „Horovy cesty”, které spojovalo nilskou deltu a jižní Palestinu. Oslabení pozice Egypta zřejmě souviselo s jeho vnitřním vývojem, kdy došlo k oslabování moci panovníka a následným reformám, které pravděpodobně podpořily ztrátu pozic vưči sousedům. Tato skutečnost se odráži i v opouštění Dolní Núbie a zvýšené aktivitě na Sinaji (JIRÁSKOVÁ, Lucie, 2009). Z těchto skutečností vyplývá, že úředníci z počátku 5. dynastie, jako byl Kaiaper, Nefernisut či Sešemnefer I., mohli ve svých hrobkách ještě mít uloženy originální syropalestinské importované zboží. Co se týče konce 5. dynastie, kdy zřejmě došlo $\mathrm{k}$ částečnému útlumu dovozu luxusních komodit díky vnějším i vnitřním politickým podmínkám, začaly se objevovat napodobeniny. Senedžemib-Inty však v rámci svého postavení nejvyššího muže egyptské administrativy jistě na originální produkt dosáhl. Oproti tomu nižší úředníci, jako byl Kaiemheset či Kar, se již museli spokojit s egyptskými imitacemi.

Úředníci panovníkư 6 . dynastie, v jejichž hrobkách byly objeveny nádoby syropalestinských forem byli pohřbeni opět z větší části v Gíze (REISNER, Georg A. a William S. SMITH, 1955, s. 76; STEINMANN, Frank, 1998, s. 162; JUNKER, Hermann, 1951, s. 102 - 103), Sakkáře - kromě polských výzkumů i v jižní části pohřebiště (JÉOUIER, Gustave, 1929, s. 13, 26), Abúsíru - Kar junior a Senedžemib - a Edfú (MICHALOWSKI, Kazimierz et al., 1950, s. 43, 48). Právě Edfú je jedním z dokladů rozšiřování privilegií a v př́padě „importů” i centrálních pohřebních zvyklostí do provincií. K tomuto posunu došlo na přelomu 5. a 6 . dynastie, kdy se v provinciích objevily úředníci nesoucí tituly dřive vyhrazené pro rezidenty hlavního města a osoby spojené s králov ským dvorem (EYRE, C. J., 1994). Jediným vezírem mezi těmito muži byl Ptahšepses Impy, který současně nesl tituly „dohližitel všech královských praci” a "dohližitel nad písaři královských dokumentü". Ovšem ani on, ani nikdo jiný zřejmě již nepatřil mezi iry-pat. Pouze tři nesli vyšší honorifický titul HAty-a, ostatní jen xtmty-bity či smr-waty. Co se týče funkcí, byli Kar junior a jeho bratr Senedžemib spojeni především se službou v zádušních chrámech a soudcovskými úkony. V Sakkáře pohřbení úředníci zastávali podobně kněžské funkce $v$ zádušních chrámech či dohliželi na chod jednotlivých činností v paláci panovníka. U Iziho v Edfú byl dochován pouze titul smr-waty.

$\checkmark$ tomto př́padě se jedná o další skupinu úředníkư střední vrstvy a dá se předpokládat, že jediný, kdo by př́ípadně mohl vlastnit originální import by byl pouze Ptahšepses Impy. Přítomnost nádob neegyptských forem v hrobkách úředníkư nižších instanci naznačuje trend, který vedl k přebírání zvyklostí výše postavených osob těmi, kteří se na hierarchickém žebříčku nacházeli niže. Ne každý si mohl dovolit vlastnit origináln dovezenou nádobu, naplněnou vzácným vínem či olejem, jejichž množství se postupem času či v určitých obdobích dočasně ztenčovalo. Již vývoj na konci 5. dynastie ukazuje, že vztahy se Syropalestinou byly snad díky reformám ve státni správě oslabeny a dováženého zboží bylo spiše poskrovnu. Pozice Egypta vưči jeho zahraničním partnerům na severovýchodě postupně slábla a s ní žejejmě i velké náklady dovážených komodit. Proto ti, kteři si ho nemohli dovolit, vyvolali poptávku po alternativním, egyptském zboží, jež vzhledem $\mathrm{k}$ principům staroegyptského náboženství plně nahrazovalo originály. $\checkmark$ rané době bronzové $I V$, která je přibližně současná $\mathrm{6} 6$. dynastií, kdy již téměř nebylo 
v Syropalestině vyráběno "kovové zboži” (GREENBERG, Raphael a Naomi PORAT, 1996), zưstala v Egyptě nadále přítomna stará tradice a úředníci nižších a středních vrstev administrativy pokračovali v ukládání velkých amfor a džbánů s vínem do svých hrobek. Je proto možné předpokládat, že většina z nádob neegyptských forem nalezených v kontextu hrobek 6 . dynastie jsou napodobeniny vyrobené z nilského bahna. Výjimečně se snad mohlo jednat o originální, ale sekundárně použité zboží. Takovou možnost nevylučuje jedna amfora ze souboru uloženého v hrobce Ptahšepsese Impyho, která je uzavřena pečetí nesoucí jméno Pepiho II (REISNER, Georg a William S. SMITH, 1955, s. 76)

O egyptské výrobě především velkých amfor podle syropalestinských vzorů svědči i obrazové doklady pocházející prímo ze soukromých hrobek z doby 5 . a 6 . dynastie. Např́klad v hrobce Ptahhotepa z 5 . dynastie pochází reliéf zachycujicí nádobu neegyptské formy prodávanou na tržišti (JUNKER, Hermann, 1941, Abb. 10). Pokud by se jednalo o originální zboží, byla by prodávána již použitá nádoba. Zahraniční výpravy nebyly soukromou záležitostí, ale státním podnikem, a tak všechny přivezené produkty patřily panovníkovi, který je dále přerozděloval. $\vee$ dalších hrobkách je již vyobrazeno použití takových nádob ( $v$ tomto prípadě bezpochybně egyptských napodobenin) v průběhu výroby vína. Jedná se o hrobky Nianchnuma a Chnumhotepa v Sakkáře z doby 5. dynastie (MOUSSA, Ahmed a Hartwig ALTENMÜLLER, 1977, Abb. 16), Šedua v Dešáše (KANAWATI, Naguib a Anne McFARLANE, 1993, PI. 53) a Fetektyho v Abúsíru (BÁRTA, Miroslav et al. 2001, Fig. 3.16), obě ze 6. dynastie.

Zkoumání tituli̊ nemusí být jedinou alternativou k chemickým analýzám. Další možností poskytující data jiného charakteru pro případ ověřování pravosti nádob syropalestinských forem je měění jejich objemu. Nabízí se předpoklad, že Egypt’ané, zvyklí používat svou tradiční dutou míru heka (přibližně 4,8 litrů) při výrobě nádob, uplatnili stejný princip i při výrobě napodobenin. Pomocí speciálního počítačového programu je na základě perokreseb s nezbytnými rozměry možné zjistit přibližný objem nádob. Změřeny takto byly všechny dostupné kusy, ovšem výsledek ukázal různorodost jejich objemů a bohužel nepotvrdil použití egyptské míry. Například v rámci souboru z pohřební komory Kara juniora, čísla 8,95 heka, 4,03 heka a 2,96 heka snad mohou potvrzovat teorii, ale zbývající 1,67 heka, 2,76 heka, 3,36 heka a 5,3 heka ji vyvraceji. Chyba v měření je nepravděpodobná, jelikož i malá odchylka vede $k$ téměř totožnému výsledku. Poměrně blízko jsou egyptské miře nádoby objevené v jižní Sakkáře v hrobkách Idiho a Wašptaha, služebníků Pepiho Il. Jedna z nich měla objem 0,91 heka a druhá 4,08 heka. Podobný výsledek přineslo měřní džbánu a amfory objevené S. Hassanem v jedné Gízké hrobce z doby 5. dynastie, stejně jako džbán z hrobky Hetepheres a několik dalších nádob z doby 4. dynastie. Vzhledem k těmto skutečnostem se zdá pravděpodobnější, že byla používána bud' jiná míra než heka, nebo byly rozměry vytvořeny náhodně. O sériové výrobě založené na egyptské miře, použivané při produkci nádob pro zjednodušeni účetních a jiných úředních počtů, se v tomto prípadě zrejmě nedá mluvit.
Ve staroegyptské archeologii poměrně často nastává situace, kdy není možné - či př́liš složité a zdlouhavé - podrobit nalezené předměty chemickým a petrografickým analýzám, prípadně různé analýzy stejného materiálu vedou k odlišným výsledkům. V takovém případě je třeba hledat alternativní možnosti, které by pomohly určit přinejmenším pravděpodobnost pravosti amfor a džbánů syropalestinských forem Nejjednodušší metodou je porovnávání celku či jednotlivých detailů s nálezy pocházejícími z domácího kontextu oblasti Syropalestiny rané doby bronzové. Užitečný ale mưže být i pohled na širší kontext, v němž byl objekt, resp. nádoba použivána a při archeologickém výzkumu nalezena. $V$ prípadě hrobového kontextu je možné zkoumat a porov návat společenské postavení majitelů hrobek a současně sledovat sociální proměny, které tvořily pozadí výbavy jejich posmrtných př́bytků. Mnohé naznačuje i vývoj vzájemných vztahů mezi oběma oblastmi, případně změny v syropalestinské hmotné kultuře. Všechny tyto aspekty naznačuji, že konec 5 . dynastie a doba následujicí 6 . dynastie byla přiznivá spíše pro vznik egyptských napodobenin než dovoz asijských originálü. Ačkoliv se počitání objemu v případě staroříšských „importư” neosvědčilo pro rozeznáván místa jejich vzniku, může přinést výsledky u jiného souboru. Variabilita velikostí zjiného úhlu pohledu napovídá, že se v případě zkoumaných objektů zřejmě nejednalo o produkty sériové výroby, přičemž tak dokládá jejich relativní vzácnost a pravděpodobně omezenost této zvláštní produkce pro určité osoby.

Literatura:

ALEXANIAN, Nicole (1999): Dahschur II. Das Grab des Prinzen Netjer-aperef. Die Mastaba II/1 in Dahschur. Mainz am Rhein: Verlag Philips von Zabern.

BÁRTA, Miroslav (2009): Abusir XIII. South Abusir 2. The Tomb Complex of the Vizier Qar and his Sons. Praha: Czech institute of Egyptology.

BÁRTA, Miroslav et al. (2001): Abusir V. The cemeteries of Abusir South I. Praha: Czech Institute of Egyptology. BÁRTA, Miroslav ( $v$ tisku): A mistake for the afterlife?

BRUNTON, GUY (1948): Matmar. London: Quaritch.

DODSON, Aidan a Salima IKRAM (2008): The tomb in Ancient Egypt. Royal and Private Sepulchres from the Early Dynastic Period to the Romans. London: Thames and Hudson.

EYRE, C. J. (1994): Weni's Career and Old Kingdom Historiography, in: Eyre, Christopher, Leahy, Anthony a Lisa Montagno Leahy, edd., The unbroken reed. Studies in the culture and heritage of ancient Egypt in honor of A. F. Shore, 5. 107 -122. London: The Egypt exploration society.

FORSTNER-MÜLLER, Irene a Dietrich RAUE (2008): Elephantine and the Levant, in: Engel, Eva-Maria, Müller, Vera a Ulrich Hartung, edd., Zeichen aus dem Sand. Streiflichter aus Ägyptens Geschichte zu Ehren von Günter Dreyer, S. 127-148. Wiesbaden: Harrassowitz Verlag.

GREENBERG, Raphael a Naomi PORAT (1996): A Third Millennium Levantine pottery production center: Typology, petrography, and provenance fo the Metallic Ware of Northern Israel and Adjacent Regions, Typology, petrography, and provenance fo the Metallic Ware of Northern Israel and Adjacent Regions,
Bulletin of the American Schools of Oriental Research $301: 5-24$ HARTUNG, Ulrich (2002): Imported Jars from cemetery $U$ at Abydos and the Relations between Egypt and Canaa 
HELCK, Wolfgang (1954): Untersuchungen zu den Beamtentiteln des ägyptischen Alten Reiches. Glückstad - Hamburg - New York: Verlag J. J. Augustin.

JÉQUIER, Gustave (1929): Tombeaux des particuliers contemporains de Pepi Il. Cairo: Institut Français d'Archéologie Orientale.

JIRÁSKOVÁ, Lucie (2009): The Relations of Egypt and Syria - Palestine in the Latter Part of the Old Kingdom, in: Duistermaat, Kim a llona Regulski, edd, Proceedings of the conference on Intercultural Contacts in the Ancient Mediterranean, Cairo 26-29 October 2008. [v tisku]

JUNKER, Hermann (1929): Giza I. Die Mastabas der IV. Dynastie auf dem Westfriedhof. Wien - Lepzig: Hölder-Pichler-Tempsky.

UNKER, Hermann (1941): Giza V. Die Mastaba des anb (Seneb) und die umliegenden Gräber. Wien - Leipzig: Hölder-Pichler-Tempsky.

JUNKER, Hermann (1951): Giza X, Der Friedhof südlich der Cheopspyramide. Wien: Rohrer.

KANAWATI, Naguib a Anne McFARLANE (1993): Deshasha. The tombs of Inti, Shedu and Others. Sydney: Warminster (Aris).

KORMYSHEVA, Eleonora (2001): Report on the activity of the russian Archaeological mission at Giza, tomb $G$ 7948 and adjoined area, east field, during the season 1999. Annales de Service des Antiquités Égyptien 76:73-81. MCFARLANE, Anne (2003): Mastabas at Saqqara. Kaiemheset, Kaipunesut, Kaiemsenu, Sehetepu and others. Oxford: Aris \& Phillips.

MICHALOWSKI, Kazimierz et al. (1950): Fovilles Franco-Polonaises, III, Tell Edfou 1939. Le Caire: Institu Français d'Archéologie Orientale.

MOUSSA, Ahmed M. a Hartwig ALTENMÜLLER (1977): Das Grab des Nianchchnum und Chnumhotep. Mainz am Rhein: Verlag Philips von Zabern.

de MIROSCHEDJI, Pierre (2002): The socio-political dynamics of Egyptian-Canaanite interaction in the Early ronze Age, in: van den Brink, Edwin C. M. a Thomas E. Levy, edd., Egypt and the Levant. Interrelations from

PETRIE, William M., MACKAY, Ernest a Gerald WAINWRIGHT (1910): Meydum and Memphis, III. London: Quaritch.

PORAT, Naomi a Yuval GOREN (2002): Petrography of the Naqada lla Canaanite Pottery from Tomb U-jin Abydos, in: Edwin C. M. a Thomas E. Levy, edd., Egypt and the Levant. Interrelations from the 4 th through the early 3 rd millennium BCE, s. 252 - 270. London - New York: Leicester University Press.

REISNER, Georg a William Stevenson SMITH (1955): A history of the Giza necropolis. Vol. 2., the tomb of Hetep-heres the mother of Cheops : a study of Egyptian civilisation in the Old Kingdom. Cambridge: Harvard University Press.

RZEUSKA, Teodozja (2002): West Sagqara. The pottery, 2001. Polish Archaeology in the Mediterranean XIII: $151-158$.

RZEUSKA, Teodozja (2003): The pottery, 2002. Polish Archaeology in the Mediterranean XIV. 144-152.

RZEUSKA, Teodozja (2004): Pottery 2003, Polish Archaeology in the Mediterranean XV, 133-140.

STEINMANN, Frank (1998): Katalog Ägyptischer Sammlungen in Leipzzig, II. Mainz am Rhein: Verlag Philips von Zabern.

STRUDWICK, Nigel, (1985): The administration of Egypt in the Old Kingdom. The highest titles and their holders. London: KPI.

WILKINSON, Toby A. H. (1999): Early Dynastic Egypt. London - New York: Routledge.

WODZINSSKA, Anna (2007): Preliminary report on the ceramics, in: Lehner, Mark a Wilma Wetterstrom, edd, Giza Reports. The Giza Plateau Mapping Project I, s. 283-324. Boston: Ancient Egypt Research Associates.

\section{Když není Cesta vykonávána: koncept přerušení daotongu v díle Yulgoka Yi I (1536-1584)}

\section{Abstract}

The present paper focuses on the interpretation of the term daotong (meaning genealogy or transmission of the Way), which formulates the basic outlines of the understanding of both history and ideological tradition of daoxue movement of Confucianism. The effort of daoxue scholars both in China and Korea to clearly delimit the succession of the orthodox Confucian tradition resulted in the belief that in many cases and historical periods the transmission simply disappeared and Confucian school was virtually nonexistent. The reasons why whole centuries of Confucian tradition were excluded from the orthodox interpretation of history, accepted by Chinese and Korean schools of daoxue, are analyzed on textual samples dealing with this issue written by Korean scholar Yulgok Yi I. His answers reveal the basic stance of orthodox scholars towards their predecessors and their criteria for defining the true transmission of Confucian tradition.

Termín daotong 道統 (korejsky tot'ong) je již od svého prvního použití v Zhu Xiho (1130 -1200) předmluvě k Zhongyong zhangju 中庸章句 jedním z úhelných kamenů pohledu čínských a korejských literátů na dějiny obecně i konfucianismu zvláště. Šíre překladů tohoto termínu se rozprostírá od „legitimního předávání Taa” (Cheng 2006: 473) až po 
genealogii Cesty” nebo „tradici Cesty. " $\bigvee$ nejširší definici je daotong systematizací otázky kdo byl (anebo je) tím, kdo plně obsáhl a uskutečnil ideály Cesty, a lze se k němu vztahovat jako ke vzoru univerzálních ctností, hodnému následování. Suchý výčet v Zhu Xiho podáni tedy uvádí linii nanejvýš moudrých mužů (shengren 聖人; korejsky sŏngin), která sahá od legendárního starověku až po současnost; Fu Xi, Shen Nong, Žlutý císař jsou následován Yaoem, Shunem, králi Tangem, Wenem, Wuem, vévodou z Zhou, Konfuciem a Menciem, po nichž následuji songští myslitelé Zhou Dunyi, bratři Chengové a v pozdějších výkladech i Zhu Xi samotný.

Základní otázka po daotongu však není, kdo tvoří linii nanejvýš moudrých mužư, ale jaké jsou vztahy mezi těmito postavami a jaká jsou kritéria pro jejich výběr, resp. co zakládá jejich privilegovaný vztah $\mathrm{k}$ Cestě. Již v tomto bodu je ale třeba opustit matoucí konotace konceptu souvislého předávání a udržováni nauky ve smyslu lineárni školy, na což nás upozorňuje i jeden z nejstarších textů (Mencius VIIb:38), na které se koncept daotongu odvolává.

„Mencius pravil: Od Yaoa a Shuna po Tanga uběhlo více než pět set let. Pokud jde o Yuho a Gao Yaoa, setkali se s nimi (Yaoem a Shunem) a pochopili (Cestu), pokud jde o Tanga, tak o nich (Yaovi a Shunovi) slyšel a pochopil (Cestu). Od Tanga po krále Wena uběhlo více než pět set let; pokud jde Yi Yina a Lai Zhua, tak se s ním setkal a pochopili (Cestu), pokud jde o krále Wena, slyšel o něm a pochopil (Cestu). Od krále Wena po Konfucia uběhlo více než pět set let a Taigong Wang a Sanyi Sheng se s ním setkali a pochopili (Cestu); pokud jde o Konfucia, slyšel o něm a pochopil (Cestu). Od Konfucia až po dnes uběhlo přes sto let. Ještě nikdy nebyla vzdálenost od generace nanejvýš moudrého člověka tak krátká a nebyli jsme tak blízko od místa, kde dlel nanejvýs moudrý člověk. Ale jestliže nebude (nikdo, kdo by pochopil Cestu), tak nikdo nebude. (Ale jestliže z toho nic nebude, pak z toho také nic nebude.)"

Tři základni ${ }^{3}$ okruhy nastolené v uvedeném textu tematizuji techniky předávání doktríny (př́imé versus zprostředkované), možnou periodicitu znovuoživení Cesty

1) Za pomoc a cenné rady při psani tohoto článku bych chtěl poděkovat Olze Lomové, Oldřichu Královi, Davidu Sehnalovi a Jakubovi Maršálkovi.

Prvnítermín používá Thomas Wilson (Wilson 1995), druhý Wing Tsit-chan (Chan 1989). 2) 孟子曰：「由堯舜至於湯，五百有餘歲；若禹臭陶見而知之，若湯則 聞而知之。由湯至於文王，五百有餘歲；若伊尹、萊朱則見而知之，

若文王則聞而知之。由文王至於孔子, 五百有餘歲; 若太公望、散宜 生則見而知之, 若孔子則聞而知之。由孔子而來至於今, 百有餘歲; 去聖人之世, 若此其未遠也, 近聖人之居, 若此其甚也; 然而無有乎 爾, 則亦無有乎爾。

3) Nutno podotknout, že ve svém zkoumáni ponecháváme stranou nesčíselné množstvi vosobě nanejvýš moudrého muže (pět set, respektive sto let) a nakonec kličové téma našeho zkoumání, situaci, kdy není jasné, kdo je nositelem Cesty anebo kdy realizace Cesty zcela absentuje. Tato otázka (kdy a kým byla Cesta realizována) nese jak náhled na dějiny co do hodnocení jejich smyslu, tak i nutnost definovat aktuální poměr tazatele spiše než k tradici minulé k situaci jeho doby (je dnes Cesta realizována?4). Symptomatická je ostatně i závěrečná pasáž citace, kde Mencius přímo vyjadřuje možný nezdar př navázání na Konfucia, a předpovídá tak i následujicí vývoj, kdy z určitého úhlu pohledu skutečne nastává přerušení tradice.

Popis naznačených možných diskontinuit a předělů v aplikaci ideálů konfucianismu budeme zkoumat na př́kladu korejského myslitele Yulgoka Yi I 栗谷 李珥 (1536 - 1584), jehož texty ${ }^{5}$ ilustrují tuto problematiku jak na príkladu čínské, tak i korejské verze daotongu.

\section{Daotong čínského konfucianismu}

Základním pramenem pro zkoumání Yulgokova náhledu je Sŏnghak chibyo 聖學輯要 (Sebrané zásady studia nanejvýš moudrého muže), rozsáhlé antologie konfuciánských textů, doprovázené Yulgokovým komentářem. Přestože vnitřní struktura tohoto textu následuje osnovu Daxue (Velké učení), poslední kapitola „Daotong nanejvýš moudrých a moudrých mužư" (Sŏnghyŏn tot'ong聖賢道統) je věnována (po vzoru Zhu Xiho a Lü Zuqianovy (1137 - 1181) antologie Jinsilu 近事錄) ortodoxní verzi daotongu. Výrazem ortodoxní míníme předevšim fakt, že použivá pouze texty, o nichž panovalo mezi korejskými literáty shodné mínění, že jsou v plném souladu s Zhu Xiho výkladem konfucianismu, což sebou paradoxně nese mimo jiné i fakt, že Sŏnghak chibyo nijak nezmiňuje problematiku daotongu v Koreji.

konotací daotongu v systémech daoxue (Studia Cesty) a orientujeme se pouze na několik základních bodů. Brilantní ukázkou hledáni nečekaných souvislotí tohoto pojmu je ale kupr. Tillman 2004

4) Otázka "Co se dnes děje?" anebo „V jaké době žijeme?" (o niž pozoruhodně pojednává Foucaultův komentár̆ Kantova textu Co je to Osvicenstvi?), byla v korejské konfuciánské tradici klasickou úlohou zadávanou často adeptům literátských zkoušek (u Yulgoka lze nalézt explicitni odpovědi na otázku po současnosti v kupř. YCHS 15:12a-14a nebo YCHS Sŭpyu 2: 25a-31b).

5) V této práci je používáno standardní edice Yulgokova díla z r. 1744 ve vydání Yulgok chŏnsŏ I-VII. 栗谷全書 (1996). Sŏul: Hanguk chŏngsin munhwa yŏnguwŏn 韓國精神 文化研究院, - dále zkracováno jako YCHS. Při přepisu korejských výrazů je používán systém McCune-Reischaver, punktuace v citacích dodržuje pưvodní členěni textu. 
Jedním z důležitých tónů uvedeného sdělení je fakt, že mimo zjevných důvo-

Úvodní paragraf Yulgokova komentáře ukazuje počátky daotongu jakožto identické se vznikem civilizace jako takové a podává jeho základní časové vymezení.

„Já dodávám, že nanejvýš moudří mužové a zázrační vládci dávného starověku navázali na Nebesa a ustavili vymezení, a to je počátek daotongu. Před vznikem pisma je toto rozptýlené a nelze to ověrit, ale když bylo poprvé zobrazeno osm trigramů, lidská kultura a civilizovanost začaly být zřetelně šiřeny, a proto když s největší opatrností podle ponaučení a výkladů souhrně prozkoumáme historické dokumenty a ve zkratce je zde vyložíme, tak (daotong) počíná u Fu Xiho a končí u Zhu Xiho."( YCHS 26:2a)

Následnost nositelů Cesty v tomto období je nicméně ve své klíčové prvn části (od legendárních počátkư až po Mencia) poznamenána silným descendenčním akcentem. Degradaci illud tempus konfucianismu, času, kdy vládli moudří císařové, a celé Podnebesí bylo v souladu s Cestou, Ize demonstrovat nejlépe na rovině rétorické a v konceptu odezvy jednotlivých postav daotongu, které jsou do značné míry nepř́mo úměrné. Čím více se ztrácí pochopení Cesty, tím více je třeba o ní mluvit. To lze ilustrovat na způsobu užití jednoho z klíčových pojmů konfuciánství „lidská přirozenost”: císařové Yao a Shun nemluví o lidské přirozenosti nikdy, protože je to věc každému známá, Kon fucius ji zmiňuje ojediněle, Mencius ji už věnuje rozsáhlé pasáže. Stejně tak ale úměrně klesá počet lidí schopných Cestu pochopit a realizovat; poté co byla vykonávána panovníky kontinuálně a pak ojediněle, se přesouvá ke Konfuciovi, v praktické politice neúspěšnému soukromníku, který však měl mnoho žáků, až zcela končí u Mencia, kterỳ nemá ani jediného následníka. Právě období následující po Menciovi je locus classicus přerušení daotongu a ortodoxní interpretace dějin konfucianismu. $V$ Yulgokově interpretaci není nikdo z konfuciánů následujicích po Menciovi (až do nástupu songských myslitelů) hoden tohoto jména.

Já dodávám, že daotong byl předáván od Fu Xiho a skončil u Mencia a poté nebylo žádné předání. Tací lidé jako Xun Qing, Mao Chang, Dong Zhongshu, Yang Xiong, Zhuge Liang, Wang Tong a Han Yu zanechali výroky a skutky které přispěly ke vzdělání své doby. Ale Xun a Yang byli př́liš jednostranní a vymezovali se vưči ostatním Mao Chang neměl žádné zřetelné zásluhy, Wang Tongovy vědomosti byly malé a vše chtěl urychlit. Na těch všech je toho jen málo hodno pozornosti. Pouze Zhongshu měl správné / ortodoxní rozpravy vhodné k osvětlení Cesty, Zhuge Liang měl způsoby konfuciána a Han Yu odmítal Buddhu a Laoziho. Ti jsou z nich nejlepší. Zhongshu však sklouzl k vysvětlování pohrom a podivného a Liang měl blízko k praktikám Shen (Buhaie) a Han (Feiziho) a Yu měl nedostatky v praktických naukách. Proto nebyli schopni navázat na Mencia." ( YCHS 26: 21b-22a)

6) 臣按。上古聖神。繼天立極。道統做始。書契以前。范乎固管。八卦肇畫。人女 始宣。故謹依謨訓。兼考史籍。略述于此。始于伏羲。終于朱子

7) 臣按。道統。傳自伏羲。止於孟子。逐無傳焉。荀卿，毛萇，董仲舒， dů pro vyloučení z daotongu, které uvádí u jednotlivých myslitelů, Yulgok nijak netematizuje nutnost kontinuálního napojení na daotong; začlenění konkrétní postavy do tradice je určováno konzistencí jejího konfucianismu v teorii a praxi, a nikoli tím, zda je mu Cesta někým předána, či ji získá nezávisle na svých předchůdcích. Tato figura je nejlépe patrná při opětovném navázání daotongu v osobě Zhou Dunyiho (1017-1073), který dle Yulgokovy citace Zhu Xiho komentáre k Taiji tu 太極圖 „nevycházel z toho, co by mu učitel předal, a mlčky načrtl základy Cesty." (YCHS 26:22b) ${ }^{8}$ Možnost nazření Cesty kýmkoliv, kdo je tomu dostatečně disponován, je samozřejmě jedním ze základních předpokladů konfucianismu a klade otázku po tom, pročje třeba znát daotong. Odpovědí může být Yulgokův popis Zhu Xiho úlohy v předávání Cesty.

„Dle mého názoru Konfucius shromáždil velkou dokonalost nanejvýš moudrých mužư (sheng) ${ }^{9}$ a Zhu Xi shromáždil velkou dokonalost moudrých mužư (xian). Nanejvýš moudrý člověk již od narození chápe a v poklidu koná ${ }^{10}$, je nezřetelný a nezanechává stopy a je obtižné se toto náhle naučit. Avšak mistr Zhu nashromáždil potřebné znalosti a dovednosti, a proto ho lze mít za vzor. Nejprve se studuje Mistr Zhu a teprve poté Konfucius." (YCHS 26:32a) $)^{11}$

Daotong je v tomto ohledu přehledem vzorů, ze kterých odvozujeme konkrétní př́klady realizace Cesty, která je neměnná, a v jistém slova smyslu je i zdưrazněním toho, že tato realizace je vždy dokonalá a nikdy parciální. Přerušení realizace Cesty od Mencia po Zhou Dunyiho je důsledným aplikováním nároku teoretické konzistence ve Zhu Xiho a Yulgokově podání. Co totiž odlišuje seznam těch, kteří nejsou součásti daotongu, je především od Konfucia dále dokonalé teoretické uchopení Cesty, které není v rozporu s předcházejícími autoritami a není kontaminováno heretickými učeními. Tento mlhavý nárok je samozřejmě zpětnou interpretací, ale jak dále uvidíme, prioritou

楊雄, 諸葛亮, 王通, 韓愈之徒。立言立事。有補於世敎。而荀, 揚皆偏 駁。毛萇無顯功。王通見小而欲速。皆少可觀。惟仲舒有正誼明道之 論。諸葛亮有儒者氣象。韓愈排斥佛老。視諸子爲優。但仲舒流於災 異之說。亮近於申，韓之暑。㸝疏於踐履之學。此所以不能接孟氏之 統也。

8) 先生不由師傳。默契道體。Gabelentz překládá „Nicht mit der Hülfe der Ueberlieferung eines Lehrers erfasste er innerlich das Wesen der Lehre." (Gabelentz 1876: 15 - 16). 9) Narážka na Mencius $5 b: 1$.

10) Lunyu zhanggujizhu $2: 3$

11) 臣按。孔子集䕜聖之大成。朱子集諸賢之大成。聖人生知安行。渾然無迹。蜼 可猝學。惟朱子積累功夫。可取以鵎模範。先學朱子。然後可學孔子。 
sařském dvoře došlo k tomu, že byl uveden do Shengmiao 聖廟, a z toho lze poznat (jaké je) učení na císařském dvoře." (YCHS 31-60a) ${ }^{16}$

Oficiální kanonizace tedy nebyla nijak závazná pro to, aby literát dané osoby respektoval jako součást své verze daotongu; ostatně ani Yulgokovými žáky neotřáslo, když byl jejich mistr "poprvé kanonizován roku 1682, odstraněn ze svatyně v roce 1689 a nakonec znovu umístěn v roce 1694." (Palmer 1984: 81) Tato lehká skepse vưči oficiálním autoritám se zdá pramenit z prostého faktu, že navzdory umístování význačných myslitelů do svatyní není nanejvýš moudrý, či alespoň moudrý člověk stále př́tomen a čas, ve kterém žijeme, je dobou, kdy Cesta není uskutečňována.

Yulgokův názor na to, jak hodnotit současnost z hlediska daotongu, je formulován ve fiktivním dialogu Tongho mundap 東湖問答 (Otázky a odpovědi od Východního jezera), který sepsal pro krále Sŏnjoa r. 1569.

„Host se zeptal: Byly i v naší Východní zemi také prípady doby, kdy se vládlo

Toto „uzávorkováni” vývoje daoxue po Zhu Xim zároveň otevírá otázku po možnostech utváření korejského daotongu, resp. zda je možné, aby za situace, kdy realizace Cesty absentuje v Číně, ji bylo možno vykonávat v Koreji.

Yulgokưv postoj $\mathrm{k}$ této otázce Ize analyzovat $\mathrm{v}$ několika rovinách, $\mathrm{z}$ nichž dvěma hlavními jsou jednak teoretické vymezení možnosti daotongu $v$ Koreji, a dále i jeho účast na debatách týkajících se kanonizace korejských konfuciánů v Munmyo 文廟 (Svatyni kultury). Relativně velká pozornost věnovaná tomuto typu kanonizace (文廟從 祀munmyo chongsa ${ }^{13} v$ porovnání s pojmem daotongu nesmí zastírat fakt, že oba dva procesy jsou diametrálně odlišné.

Zatímco kanonizace v Munmyo je oficiálním aktem, se kterým Ize individuálně souhlasit či nesouhlasit ${ }^{14}$, a je záležitostí konsensu dvora a literátů, daotong se s osobami oficiálně kanonizovanými nemusí krýt a je povýtce záležitostí vlastního vkusu. $\checkmark$ tomto ohledu Yulgok zpochybňuje kandidáty kanonizace nejen v korejské Munmyo („Kim Mungyŏng (Koengp'il) a Chŏng Munhŏn (Yŏch'ang), jejich výroky, pojednání i naučení jsou tak nepatrné, že se neprojeví navenek a Yi Munwŏnova (Ŏnjŏk) východiska jsou tam, kde se ukáží, nesprávná a diskutabilni.." $\left.{ }^{15}\right)$, ale i kupř. Wang Yangmingovu kanonizaci v Číně. K jeho osobě se vyjádřil slovy:

„Wang Shouren je nazýván pohromou, jejiž škody na (učení) Mistra Zhu jsou vážnější než záplavy a divá zvěř́; z toho lze poznat, jaké je jeho učení. Říká se, že na cí-

12) 朱子之後。得道統正脈者。無可的指之人。

13) Patrně nejlepšístudiíj je v tomto ohledu Kim Yŏngdu: 2005.

14) U Yulgoka najdeme ostatně i pasáž, kde odmítá fakt, že mnoho již kanonizovaných postav korejského konfucianismu, jako je kupř. Sŏl Ch'ong, Ch'oe Ch'iwŏn nebo An Hyang, je uctíváno v Munmyo, a doporučuje jejich kult realizovat na jiném mistě (YCHS 29:12b-13a).

15)金文敬觙文戲則言論風旨。微而不顯。李文元則出處頗有可議者。
Pán domu odpověděl: Písemné doklady jsou nedostatečné a nelze to dokázat, ale myslím, že Jiziho ${ }^{17}$ vládnutí našemu Východu, jeho systém studničních poli a osm článků výchovy vycházely čistě a v celosti z královské Cesty. Po něm se jako trojnožka ustavila Tři království a Koryŏ je sjednotilo, ale pokud prozkoumáme jejich jednání, pak se pouze potírala znalostmi a silou a kdo z nich chápal, že Studium Cesty je to, co Ize klást na nejvyšší místo? Nebyli to jen vládci, kteři byli takoví, i ti, kteří byli pod nimi, neslyšeli o pravém poznání a skutečném jednání, kterým by pokračovali v předáván toho, co bylo správné dřive. Byli podvedeni indickým učením, přilákáni bohatsvím a zastrašeni pohromami a uběhlo tisíc let a nebylo nikoho, kdo by vynikl nad houštinu. Na konci Koryŏ měl Chŏng Mongju v sobě něco z konfuciánského ducha, ale také neby schopen uspět v uskutečňování tohoto studia , a sledujeme-li stopy jeho konání, pak nebyl ničím více než věrným poddaným.

Host nespokojeně řekl: Ty se domníváš, že na našem Východě nebyl po ně kolik tisíc let ani jeden pravý konfucián. Nejsou tato slova přehnaná?

Pán domu se usmál a řekl: Zeptal ses mne a já se neodvažuji odpovědět nepravdivě. ${ }^{18}$ Proč bych měl mít zálibu v přehnaných slovech? Ten, kdo se nazývá opravdovým konfuciánem, když vstoupí do služby, pak po určitou dobu vykonává Cestu a pưsobi

16)王守仁則以謂朱子之害。甚於洪水猛獸之禍。其學可知。而中朝至乃從祀於聖 廟云。中朝之學。可知。

17) K Jiziho roli při konstruování korejských dějin jsou inspirativní zejména Chŏng Haengnyŏl 2001, Han Young-woo 1985 a Jae-hoon Shim 2002. K pozornosti je téź fakt, že autorem jednoho z nejdůležitějš̌ich pramenů k této problematice, spisu Kija silgi 箕子貝 記 (Skutečné zápisky o Jizim), byl sám Yulgok (viz.YCHS 14:19a).

18) Mencius $5 b: 9$. 
žákům v ústraní. I přes tuto benevolenci však není nikdo, kdo by i tyto minimální podmínky splňoval. generací a způsobuje, že učenci se probouzejí z velikého spánku. Když ve službě dokáže vykonávat Cestu, ale po odchodu do ústraní nemá učení, které by předával, pak byt' by se nazýval pravým konfuciánem, já tomu neuvěřim.

Poté, co Jizi proměnil barbary Yi, nebylo znovu dobré vlády, kterou by bylo možno se řídit - to byla situace, kdy lidé ve službě nevykonávali Cestu. Ve spisech, které napsali lidé Východní země, jsem ještě neviděl, co by bylo hluboké a jasné co do smyslu a principů, - to znamená, že mezi těmi, kdo se stáhnuli do ústraní, nebyl nikdo, kdo by předával učení. Což bych chybnými výroky pomlouval sto generací? Výše je diskutováno to, že ve Východní zemi není Cesta vykonávána." (YCHS 15:8b-9b) ${ }^{19}$

Yulgokův model korejského daotongu si zachovává rysy svého čínského vzoru; po počátečním ideálním stavu, který je reprezentován legendou o Jizim, následuje pauza, naplněná rozkvětem heretických učení, a není nikdo, koho by šlo považovat za pravého konfuciána. Stejně jako v čínské verzi se sice v tomto období vyskytli někteři kandidáti (Chŏng Mongju), ale nesplnili kritéria, která pro definici pravého konfucián Yulgok stanoví. Je pozoruhodné, že tato kritéria nikdo nesplňuje ( $v$ tomto konkrétním textu ${ }^{20}$ ), byt 'j jsou nastavena daleko volněji, než bychom očekávali. Výše uvedený odklon od praktických zásluh ve smyslu vlády či podílu na ní směrem k teoretické vybavenost jakožto předpokladu zařazení do daotongu demonstruje, že Yulgokova kritéria jsou nastavena jak pro dobu, která působení nanejvýš moudrého muže přeje (vstupuje do služby a veřejně pưsobí), taki pro okolnosti, kdy věrejně pưsobit nelze a tradice je předávána

19）客曰。吾東方。亦有以王道治世者乎。主人日。文獻不足。無可放 者。但想箕子之君于吾東也。井田之制。八條之敎。必粹然一出於王 道矣。自是厥後。三國鼎峙。高麗統一。考其事業。則專以智力相勝。 夫孰知道學之爲可向耶。不特邦君爲然也。下焉者。亦不聞眞知實 踐。以紹先正之傳。詿誤于竺學。「迫于禍福。滔滔千載。莫或拔萃。 麗末。鄭夢周稍有儒者氣象。亦未能成就其學。迹其行事。不過爲忠 臣而已。客艴然曰。子以営吾東數千載之閒。無一眞儒。何言之過高 耶。主人笑日。子問我。我不敢不以正對。峝其樂爲過高之論耶。夫 所謂眞儒者。進則行道於一時。使斯民有熙「之樂。退則垂敎於萬世。 使學者得大棩之醒。進而道可行。退而無教可垂。則雖謂之眞儒。吾 不信也。箕子變夷之後。更無善治之可法。則是進無行道者矣。東人 所著之書。未見深明乎義理。則是退無垂敎者矣。吾豈妄言以誣百代 之人耶。右論東方道學不行

20) Yulgok v několika textech projevuje ochotu uznat některé myslitele (jmenovitě Y Hwanga a Cho Kwangjoa) za reprezentanty daoxue v Koreji, nicméně tyto výroky obsažené v Kŏngyŏn ilgi 經延日記 (Deník dvorských lekcí), Ŏrŏk 語錄 (Záznam slov) nebo Haengjang 行狀 (Skutky) jsou formulovány v dosti odlišných situacích.

\section{Závěr}

V Yulgokově verzi daotongu se tedy nacházíme v období, kdy není realizována Cesta jak v Číně (kde byl poslední nezpochybnitelnou autoritou Zhu Xi), tak v Koreji (kde byl naposled uskutečněn $v$ dávném starověku). Tento pesimistický náhled na dějiny i současnost je však současně manifestem povzbudivé ortodoxie. Čím více jsme vzdáleni vzorům nanejvýš moudrých mužǔ, kteři tvoři daotong, tím více jsme odkázáni na studium, které nám jejich odkaz zprostředkovává. Druhým aspektem tohoto konceptu je pak čitelnost celé tradice; uzávorkováním dlouhých období, kdy není z hlediska daotongu Cesta realizovaná, se vyhneme nutnosti polemik s autory působícími v daných usecích a zejména se současníky. Étos odmítnutí všeho mimo nezpochybnitelné vzory minulosti a pobyt v době, kdy neni Cesta vykonávána, spočivá ale především v tiché nevyřčené naději, že každý student daoxue se může stát tím, kdo na přerušené vlákno daotongu opět naváže. Odvahu k tomuto kroku pak Ize čerpat nikoliv z tradice, která je nám vzdálená hluboko v minulosti, a její články jsou v poklasickém období zpochybnitelné, ale naopak z odmítnutí stavu současného a bezprostředně předcházejícího období. $Z$ hlediska korejského konfucianismu se tak v Yulgokově podání formuje názor, že lépe než se opírat o tradici nejasnou je lepši se vzdát kontinuity tradice a vztahovat se pouze k nezpochybnitelným autoritám, a právě studium nám poskytuje možnost překonat toto uzávorkování části vývoje vlastní školy a vztáhnout se přímo k okamžiku, kdy byl daotong naposledy nepochybný a zřetelný.

Literatura:

AN OESUN (2005): Tongho mundap. Sŏul: Ch'aeksesang.

CHANG SEHO (1996): Kihohakp'aǔi tot'ongǔisik. Chǒrhak nonch'ong 12: 299 - 333.

CHENG A. (2006): Dějiny čínského myšlení, DharmaGaia.

CHŎNG SUNU (2002): T'oegye tot'ongnonǔi yŏksa ǔimi. T'oegye hakpo 111: 1 - 42.

CHŎNG HAENGNYŎL (2001): 16 - 17 segi Chosŏn sŏngnihakchadŭlŭi Kijae taehan insik pyŏnhwan. Sŏul: Sŏnggyungwan taehakkyo. Columbia University Press.

HAN Young-woo (1985): Kija Worship in the Koryo and Early Yi Dynasties: A Cultural Symbol in the Relationship Between Korea and China. in: The Rise of Neo-Confucianism in Korea, Columbia University Press 348 - 374 HWANG CHUNYǑN (2000): Yi Yulgok, kŭ salmi mosǔp. Sŏul: Sŏultaehakkyoch'ulp'anbu.

YISŎNJU, ed. (2002): Chosŏn yuhakǔi kaenyŏmdŭl. Sŏul: Yemun sŏwŏn.

IM HONGT'AE (2006): Yulgok Yi lǔi tot'ongnongwa tot'ong ǔisik- Sŏnghak chibyoǔi Sŏnghaktot'ongnonǔl chǔngsimưro. Hanguk chŏrhak nonjip 18: 45-69.
DE BARRY, Theodore Wm, HABOUSH, Jahyun Kim ed. (1985): The Rise of Neo-Confucianism in Korea, 
(ke kterému se Lewis často a hrdě hlásí), od analogií zpưsobených skutečností, že oba autoři čerpali z týchž literárních zdrojư, a také od analogií, které není snadné a zřejmě ani možné s jistotou přiřadit k žádné z předchozích dvou kategorií a které do značné míry souvisí s podobným temperamentem, vkusem a světonázorovým zakotvením obou myslitelů.

\section{Paralely}

Paralel mezi typickými rysy Chestertonových a Lewisových literárních děl je celá řada. Jak konstatují znalci života a díla obou spisovatelů, některé z těchto paralel pravděpodobně nemaji svưj původ ve vlivu Chestertonových knih na Lewisovo myšlení, ale souvisejí s celkem „náhodnými” okolnostmi, jako je jistá podobnost jejich životopisu (MARTIN , 1978), např́iklad skutečnost, že oba (až) ve zralém dospělém věku konvertovali ke křestanské viře, a to $v$ obou prípadech predevším vlivem četby a veřícich prátel (MACKEY, 1998, s. 76).

Dále je to nápadná a nepopiratelná podobnost jejich temperamentu (KRANZ, 1991, s. 323), napřiklad charakteristický smysl pro humor (PETERS, 1997, s. 104 MACKEY, 1998, s. 81, KRANZ, 1991, s. 324), a zároveň záliba v polemice a ve tř́ibeni názorů prostřednictvím diskuse a slovního šermu (MACKEY, 1998, s. 81).

Záliba v polemice, evidentní u obou autorů, zřejmě prispěla ke skutečnosti, že oba myslitelé s využitím podobných literárních a argumentačních strategií ve svých dílech vášnivě bojují proti "duchu doby” - proti typickým ideologiím modernity, např pozitivismu, naturalismu, scientismu atd. (AESCHLIMAN, 1983, s. 10n, STONE DALE, 1988, s. 212, WALCZUK, 1991, s. 317, KRANZ, 1991, s. 327nn), a že oba podobným způsobem proti soudobým kulturním trendům statečně hájí tradici, tradiční hodnoty a vůbec odkaz starověké a středověké křestanské civilizace (AESCHLIMAN, 1983, s. 8, WALCZUK, 1991, s. 314, STONE DALE, 1988, s. 210), a to včetně její důvěry v rozum (AESCHLIMAN, 1983, s. 4, PATRICK, 1991, s. 351)1 a v dobrotu Božího stvořeni $\left(\right.$ WRIGHT, 1991) ${ }^{2}$

1) V této věci je ovšem mezi Lewisem a Chestertonem prece jen určitý rozdíl. Jak konstatuje James Patrick, Chesterton chovájako dobrý katolik a tomista podstatně větši dưvěru $v$ rozum a rozumnost stvoření, Lewis jako typický protestant pohliží na lidský rozum smenší mírou důvěry, protože poněkud silněji než Chesterton zdưrazňuje důsledky Pádu lidstva a z něj pramenicí důsledky pro schopnosti lidského rozumu a jeho spolehlivost (PATRICK, 1991, s. 354n)

2) I v této věci je mezi Lewisem a Chestertonem jistý rozdíl. Jak si všimá John Wright, Chestertonova divvěra $v$ dobrotu stvorení ( $a$ z ni pramenící spiritualita radosti a vděčnos ti) je evidentní a neochvějná, Lewis byl svým založením spiše pesimista a podle Wrighta mu právě četba Chestertonových knih pomohla k (částečnému) překonání pesimistické-
Mezi povahové dispozice obou literátů zřejmě patři také pro oba charakteristický „dětský pohled na skutečnost” (BOYD, 1989, s. 3, MILWARD, 2001, s. 69). Právě toto pro oba myslitele př́značné „dětské" vnímání skutečnosti chránilo jejich důvěru $\checkmark$ rozum před ustrnutím $v$ abstraktním racionalismu. Oba literáti kladli právě tak velký dưraz na imaginaci, tedy na zpưsob vnímání reality, přiznačný právě pro dětský věk. Přístup Chestertona i Lewise ke skutečnosti i jejich osobitá teologie se vyznačovaly, jak ještě uvidíme, právě hledáním rovnováhy a komplementarity rozumu a imaginace (STONE DALE, 1988, s. 206)

Důvěra v rozum, založená na důvěře v uspořádanost a smysluplnost Božího stvoření, spojená s důvěrou v imaginaci, vycházejíci z dětského pohledu na skutečnost, a také s nostalgickou "touhou”, kterou oba od dětství zakoušeli (DANIELS, 1981, s. 6) ústila u obou literátů, a velmi podobným zpưsobem, ve spiritualitu „vděčnosti a úžasu” (BOYD, 1991, s. 304, DANIELS, 1981, s. 4, 11, KRANZ, 1991, s. 324).

Tuto zvláštní a pro oba myslitele charakteristickou spiritualitu vděčnosti a úžasu" př́padně ilustruje jejich záliba v pojetí lidského života i celého vesmíru jako slavnostního rituálního "tance”. Oba milují metaforu tance jako dynamické harmonie hravosti a formy, radosti a vznešenosti. Tento symbolický obraz tance je u obou myslitelü klíčovou metaforou jejich kosmologie a antropologie (DANIELS, 1981, s. 3nn).

Vzhledem ke zmíněným podobnostem $v$ temperamentu, vkusu a způsobu myšlení a vyjadřování konstatují znalci obou spisovatelů, porovnávající jejich díla, že mezi Chestertonem a Lewisem je jakási evidentní "korespondence v duchu” (DANIELS, 1981 , s. 2) ${ }^{3}$. V následující části se zaměříme na další důvody podobnosti mezi literárními díly Chestertona a Lewise, souvisejícími se společnými zdroji inspirace.

\section{Společné zdroje}

Výše zmíněná metafora tance je dobrým přikladem metodologického úskalí, o kterém byla řeč v úvodu. Jistě není vyloučené, že Lewis byl inspirován k jejímu užívání také četbou Chestertonových knih. Mnohem pravděpodobnějš́ je ale předpoklad, jak konstatuje napríklad znalec díla obou spisovatelů Gisbert Kranz, že Lewis i Chesterton jako znalci a milovníci středověké literatury vděčí za tuto metaforu Dantemu (KRANZ, 1991, s. 324).

Společnými zdroji inspirace obou neobyčejně vzdělaných a zároveň věříích spisovatelů jsou pochopitelně obecné zdroje evropské křest’anské kultury a vzdělanosti tedy odkaz antiky, Bible, patristická, středověká a renesanční literatura a klasická díla novověkých dějin světové a zejména britské literatury. Tyto společné zdroje inspirace

ho pohledu na svět (WRIGHT, 1991, s. 341nn)

3) Kdalšim paralelám mezioběma mysliteli viz takésborník MACDONALD a TADIE (1989). 
jsou ovšem natolik všeobecné a evidentní, že zřejmě není nutné se jimi v rámci tohoto článku podrobněji zabývat.

Pravděpodobně nejdůležitější společný inspirační zdroj, který dalekosáhle poznamenal způsob myšlení a psaní obou autorů, je ovšem velmi konkrétní a naprosto zřejmý: byly to pohádkové knihy skotského duchovního George MacDonalda (1824 1905). Oba spisovatelé konstatuji, že četba MacDonaldových pohádek byla pro ně naprosto přelomovou zkušeností, dokonce měla podle všeho iniciační charakter, protože, jak oba konstatují, četba MacDonalda byla pro oba literáty začátkem cesty, která vyvrcholila konverzí.

Chesterton řiká o MacDonaldově knize The Princess and the Goblin, že tato kniha změnila celý jeho život, pomohla mu vnímat svět určitým zpưsobem, a tato změna vnímání byla „tak zásadní, že i tak významný přelom, jako náboženská konverze, jj v podstatě jen završil a potvrdil" (MACKAY, 1998, s. 71). Těžko si představit silnější slova ohledně vlivu konkrétní knihy na život a myšlení jednotlivce.

Je velmi zajímavé, že Lewis říká o své čtenářské zkušenosti s MacDonaldovou knihou Phantastes něco velmi podobného: když se do ní v mládí náhodou začetl ve vlaku, ocitl se náhle jakoby v jiném světě. Když později komentuje tuto zkušenos $\checkmark$ předmluvě $k$ antologii George MacDonalda, řiká, že toho dne „byla jeho imaginace obrácena" (LEWIS, 1962, s. 26), ve své autobiografii Zaskočen radostí říká dokonce, že onoho dne „byla jeho imaginace pokřtěna” (LEWIS, 1994, s. 121).

Lewisova konverze ke křestanství následovala až po mnoha letech, nicméně stejně jako Chesterton Lewis konstatuje, že rozhodujicí proměna vidění či vnímání světa, která byla začátkem cesty $\mathrm{k}$ viř̌e, se odehrála právě pod vlivem četby MacDonalda.

Není proto nikterak překvapující, že znalci díla obou spisovatelů konstatuji, že podobnost mezi Chestertonem a Lewisem do značné míry souvisí s faktem, že mají společného pohádkového kmotra", kterým je právě MacDonald (STONE DALE, 1988, s. 208). $\checkmark$ Chestertonově i v Lewisově díle nalézají zvláštní "sakramentální mysticismus” (BOYD, 1989, s. 1, PETERS, 1997, s. 133n), tedy symbolicko-sakramentální pojetí přírody, za které Chesterton i Lewis vděčí právě MacDonaldovi (BOYD, 1989, s. 1, BOYD, 1991, 303n).

Sakramentální mysticismus, prítomný v pohádkových knihách George MacDonalda, který Chestertona i Lewise hluboce okouzlil a který si posléze oba osvojili, spočivá v přesvědčení či tušení, že příroda a její krása je plna mystického světla či slávy. Není to jen mrtvá materie, príroda svou krásou, rozmanitostí a vznešeností odkazuje za sebe či nad sebe, $k$ duchovní skutečnosti, jejímž je projevem. Př́roda či přesněji stvořeni je tedy v tomto pojetí vlastně svátostným znamením, je to „Boží plášț”, halící Boží slávu, tedy symbolický, svátostný odkaz k nestvořené, duchovní skutečnosti (WALCZUK, 1991، s. 319n) $)^{4}$. Je všeobecně známo, že Chesterton i Lewis ve svých dílech z tohoto spirituálního pojetí přírodní krásy vycházejí, méně známá je skutečnost, že, jak oba vyznávají, jejich učitelem v tomto zpưsobu vnímání byl právě skotský reverend a spisovatel MacDonald.

\section{Prímý vliv-doklady}

Po stručném nastínění nejvýraznějších paralel mezi Chestertonem a Lewisem a představení jejich zřejmě nejdůležitějšího společného zdroje inspirace je nyní na řadě pojednán o Lewisových explicitních vyjádřeních ohledně literárního vlivu, kterým na něj Chesterton zapưsobil ${ }^{5}$. Lewis se cítil Chestertonovi hluboce zavázán a nijak se s tím netajil ${ }^{6}$. Například v polemickém článku, napsaném na obhajobu Chestertonova díla před zřejmě nespravedlivou kritikou, se Lewis mimo jiné přiznává, že v době nejhlubší beznaděje za války si s př́itelem prostě recitovali sloku za slokou z Chestertonovy knihy Ballad of the White Horse. "Nic jiného se tehdy nedalo ríct", vzpomíná Lewis (LEWIS, 1991, s. 301).

Ve své autobiografii vypráví o první literární zkušenosti s Chestertonovým dílem ve věku dvaceti let, když byl hospitalizován ve vojenské nemocnici v Le Tréport ${ }^{\dagger}$ A právě tady jsem poprvé četl Chestertonovy eseje. Nikdy jsem o něm neslyšel a nevěděl jsem, co je zač, a dosud ani nechápu, proč si mě tak okamžitě získal. Dalo by se očekávat, že mưj pesimismus, mưj ateismus, má nenávist vưči sentimentu způsobí, že Chesterton se pro mě stane tím nejnepřijatelnějším autorem. ... Oblíbit si autora může být děním stejně nepravděpodobným a nedobrovolným jako zamilovat se. Byl jsem v té době už natolik zkušený čtenář, že jsem dokázal rozlišit náklonnost od souhlasu. Nepotřeboval jsem souhlasit s tím, co Chesterton říkal, aby se mi to líbilo. ...Pro kritiky, kteř pokládají Chestertona za lehkovážného či „,paradoxního”, mohu mít přinejlepším lítost ale vůbec ne sympatie". (LEWIS, 1994, 127).

přece jen jistý rozdíl. Chesterton je ve svém prítakáni stvořenía jeho dobrotě a kráse jednoznačnější, svátostný charakter prírody spojuje především s naukou o Vtělení, naproti tomu Lewis zdưrazňuje spiše nauku o vykoupení, resp. o porušenosti stvoření hríchem. I v této otázce se podle Boyda projevuje Chesterton jako typický katolik a Lewis jako ty pický protestant (BOYD, 1991, s. 309nn).

5) Vliv Chestertona na Lewise byl prostředkován výhradně literárními texty, nikdy se totiž osobně nesetkali.

6) V Lewisově prísně výbèrové osobni knihovně bylo po jeho smrti nalezeno šest svazkü Chestertonových esejů a několik svazků jeho poezie (WRIGHT, 1991, s. 340).

7) Slušíse na okraj poznamenat, že Lewis sev této věci zřejmě dopustil drobné chyby. Jak vyplývá z jeho dopisu príteli Arthuru Greevesovi z listopadu 1917, četl Chestertona už o několik měsiců dř́ve nežv nemocniciv Le Tréport, kde pobýval vúnoru 1918 (WRIGHT, 1991, s. 339). 
Posléze Lewis vzpomíná, že četba Chestertona na něj měla zásadní vliv také $\checkmark$ jeho duchovním hledání, srovnatelý s výše popsaným vlivem George MacDonalda: „Při čtení Chestertona, stejně jako při čtení MacDonalda, jsem neměl tušení, do čeho jsem se zapletl. Mladý muž, který si preje zůstat zdravým ateistou, nemůže být dost opatrný ve vybírání četby". (LEWIS, 1994, s. 128) O něco později Lewis s jistou dávkou humoru vzpomíná na zvláštní dilema, které v mládí při četbě Chestertona prožíval: "Chesterton měl více důvtipu než ostatní moderní autoři dohromady; samozřejmě, až na své křest’anství". (LEWIS, 1994, s. 141).

Posléze se Lewisovi dostala do ruky Chestertonova kniha, která měla pro jeho dalši směřování naprosto rozhodujicí vliv: „Pak jsem četl Chestertonova Věčného člověka a poprvé jsem viděl křestanský nárys dějin předvedený ve formě, která podle mého dávala smysl. ... Jistě si pamatujete, že jsem považoval Chestertona za nejrozumnějšího člověka na světě „s výjimkou jeho krestanství". A nyní, pevně tomu věřím, jsem si myslel - samožrejmě jsem to neřekl, slova by vyjevila nesmyslnost té myšlenky - že křestanství samo o sobě je velmi rozumné „s výjimkou jeho křestanstvi”. (LEWIS, 1994 s. 148). Chestertonova kniha Věčný člověk měla, jak Lewis konstatuje, rozhodujíci vliv na jeho duchovní zrání a prímo a zásadním způsobem přispěla, jak ještě uvidíme, $\mathrm{k}$ jeho konverzi ke křestanské viř́e.

Ještě na úplném sklonku života Lewis uvedl v odpovědi na anketní otázku časopisu The Christian Century ohledně knih, které nejvíc ovlivnily jeho život, Chestertonova Věčného člověka hned na druhém mistě̌. Také v rozhovoru se Sherwoodem Wirtem, který se odehrál 6 . května 1963, tedy jen několik měsíců před Lewisovou smrti (v listopadu téhož roku), řiká: „Současná kniha, která mi pomohla nejvíc, byl Věčnýčlověk od G. K. Chestertona" (LEWIS, 1970, s. 260). Dále například v osobním dopise z roku 1961 říká, že v otázce obhajoby křestanství vưči moderním námitkám „....neznám nic lepšího než Chestertonova Věčného člověka" (LEWIS, 1988, s. 497).

Není tedy nijak překvapující (vzhledem k tomu, že Chestertonův vliv na Lewise byl obrovský a zcela přiznaný), že znalci Lewisova díla hovoří o tom, že Lewis hájil "chestertonovské křest’anstvi” (CARPENTER, 1979, s. 155), že psal "chestertonovským stylem" (CARPENTER, 1979, s. 181 a 218), že na Lewise "padl Chestertonưv plášt” (MILWARD, 2001, s. 66 a 69), že byl v jistém smyslu "Chestertonovým nástupcem” (KRANZ, 1991, s. 324) a že Chesterton byl Lewisovi "modelem v mnoha způsobech chápání víry" (CARPENTER, 1979, s. 217). V čem ale konkrétně spočíval vliv oné Lewisem tolikrát vděčně zmiňované Chestertonovy historické studie Věčný člověk?

8) Na prvním mistě uvedl př́značně výše zmíněnou MacDonaldovu knihu Phantastes. Viz k tomu The Christian Century, Chicago, 6. června 1962.
Přimý vliv-ideje

Poté, co jsme krátce pojednali o obecných paralelách mezi Chestertonem a Lewisem o společných inspiračních zdrojích a o Lewisově explicitní reflexi Chestertonova vlivu bude snad na místě stručně pojednat právě o několika kličových myšlenkách Chestertonovy studie duchovních dějin starověku, nazvané Věčný člověk, které se staly rozhodujícími stavebními prvky Lewisova myšlení.

Chesterton ve své knize Věčný člověk (a také ve slavné stati Etika říše pohádek svého bestselleru Ortodoxie), představuje zvláštní pojetí imaginace, které je blízké teorii imaginace německého a britského romantismu, a které si osvojil i Lewis: imaginace není v tomto pojetí chápána jako zdroj či zřídlo svévolně utvářených obrazư či jiných obsahů vědomí, je chápána jako nástroj vnímání či intuice, jako „čidlo”, které ohledává skryté stránky skutečnosti.

Právě v tomto pojetí imaginace spatřují někteři znalci Chestertonova a Lewisova díla jednu z nejdůležitějších paralel mezi nimi (STONE DALE, 1991, s. 208). Peter Milward se domnívá, že Lewis byl ve svém pojetí imaginace hluboce inspirován právě Chestertonem, zejména jeho statí Etika říše pohádek, a to snad ještě víc než jeho knihou Věčný člověk (MILWARD, 2001, s. 69).

Nicméně je to právě kniha Věčný člověk, ke které se Lewis, jak jsme viděli výše, odvolává nejčastěji a kterou hodnotí nejvýše. Chesterton v ní totiž neprezentuje své pojetí imaginace izolovaně, ale jako vysvětlení vztahu podobnosti mezi pohanskou mytologií a př́během Ježiše Krista. Právě v této otázce totiž spočival pro mladého Lewise kámen úrazu, který mu bránil vzít vážně křestanské pojetí skutečnosti.

Pohanskou mytologii totiž od dětství miloval, ale byl si zároveň až príliš dobre vědom skutečnosti, že mýty vyprávěji o fiktivních hrdinech, o neexistujících postavách. Nakolik se přiběh Ježiše Krista nápadně podobal príběhům násilně umírajících a posléze $k$ životu procitajících bohů, natolik je stejně mytologický, a tedy nepravdivý, jako všechny ostatní. Tento závěr, vyplývající ze slavné studie Jamese George Frazera Zlatá ratolest, Lewis v mládí přijal za svưj a křestanství pro něj tudiž nebylo reálnou mož ností životní orientace (LEWIS, 1988, s. 52).

Chesterton ovšem v knize Věčný člověk nabizí jiné vysvětlení podobnosti mezi „pohanskými kristy” (tedy mytickými přiběhy bohů, kteři projdou vykupujicím utrpením a smrtí a povstanou k novému životu) a přiběhem Ježíše Krista, a to právě s využitím výše uvedené teorie imaginace: je-li imaginace nástrojem tušení a intuitivního vnímání, můžeme chápat pohanskou mytologii jako prorocký sen, jako duchovní hledání (search), jako tušení pravdy (CHESTERTON, 1955, s. 103, 107, 114n, 177).

Lewis ve své autobiografii explicitně odkazuje na Chestertonova Věčného člověka jako na knihu, která mu pomohla vyřešit tuto hádanku a odstranit prekážku na cestě k viře: "Pohanství bylo jen dětstvím náboženstvi či jen věšteckým snem. Kde ta záležitost plně dorostla? Kde se odehrálo probuzení? (Věčný člověk mi tu pomohl)". (LEWIS, 1994, s. 156). 
Chesterton se ovšem ve své studii Věčný člověk neomezuje pouze na imaginaci a jeji úlohu v hledání či tušení duchovní pravdy ve starověku. Rozum (tedy logos filosofů) hrál podle Chestertona v duchovních dějinách lidstva právě tak důležitou úlohu jako imaginace. Podle Chestertona tedy vlastně ve starověkých dějinách probíhalo hledání poslední (transcendentní) skutečnosti ve dvou komplementárních rovinách, ve fi losofickém tázání po posledních principech skutečnosti a v imaginativním tušení č ohledávání duchovní pravdy. Obě tyto roviny se nakonec podle Chestertona sbíhají a dosahují smiŕení či syntézy v príchodu Ježíše Krista.

Stejně jako Chesterton, i Lewis nakonec (s jeho vydatnou pomocí) dospě k pojetí evangelijního přiběhu Ježíše Krista jako smiření historie a mýtu, filosofické reflexe a básnické intuice, rozumu a imaginace: „Tady a jen tady v celém čase se mýtus musel stát skutečností: Slovo tělem, Bůh člověkem. Tohle není ani „náboženstvi”, ani „filozofie". Je to jejich výsledné shrnutí a jejich uskutečnění". (LEWIS, 1994, s. 157).

A tím se dostáváme k nejdůležitějšímu a nejzřetelnějšímu vlivu Chestertonova díla na Lewisovo myšlení. Chesterton ve svých dílech, především v knize Věčný člověk originálním způsobem představuje křestanství jako smiŕení fantazie a historie, mytologie a filosofie (CHESTERTON, 1955, s. 113 a 251). Symbolicky je toto smiřeni v Chestertonově Věčném člověku ilustrováno setkáním prostých pastýřů a učených mudrců u jeslí v Betlémě (CHESTERTON, 1955, s. 182). Právě v Chestertonově knize Věčný člověk tedy Lewis nalezl myšlenku, že v Kristu se „mýtus stal historickou skutečnosti” (CHESTERTON 1955, s. 251nn), kterou posléze proslavil v řadě svých knih a apologetických esejů, např́klad v článku příznačně nazvaném Mýtus se stal skutečností (LEWIS, s. 66).

Chestertonova myšlenka, že v Kristu přišel na tento svět ten, o kterém snili mýtopravci a o kterém spekulovali filosofové (CHESTERTON, 1955, s. 270nn), se stala jedním ze základních motivů Lewisova myšlení a jeho literární tvorby. Svým pojetím vztahu mytologie a filosofie, tedy svým pojetím imaginace a rozumu, nalézajících smíření v příchodu Ježíše Krista, pomohl Chesterton Lewisovi najít v evangeliu smiřeni dvou dimenzí jeho vlastního nitra, imaginace a rozumu (LEWIS, 1994, s. 114, LEWIS 1992, s. 206nn, WRIGHT, 1991, s. 345) ${ }^{9}$.

Právě toto jedinečné pojeti vztahu rozumu a imaginace, a také vztahu evangelia a mytologie, Lewis zpopularizoval a učinil slavným v celé řadě svých děl, od Letopisů Narnie přes četné apologetické eseje až po Velký rozvod a Kosmickou trilogii. Skutečnost, že "pohádkovým kmotrem” Lewisovy osobité literární tvorby na rozhran imaginace a reality, poezie a prózy, dětského úžasu a moudrosti zralého věku, je právě Gilbert Keith Chesterton, je dosud mezi Lewisovými čtenáři málo doceněna.

9) Hledání harmonie a smiřeni těchto dvou rozměrů vlastního nitra, tedy rozumu a imaginace, či hlavy a srdce, je ústředním motivem Lewisova alegorického autobiografického vyprávěni o cestě ke konverzi, nazvaného Pilgrim's Regress (viz Seznam použité literatury).
V tomto článku jsem stručně rekapituloval stav bádáni o dalekosáhlém a mnohostranném vlivu G. K. Chestertona na C. S. Lewise, přičemž jsem se pokusil rozlišit paralely a obdoby mezi jejich zpưsobem myšlení a vyjadřování, jejichž pưvod je náhodný nebo mlhavý (každopádně však nemusí spočivat ve vlivu Chestertonova díla na Lewise), od paralel, jejichž původ je ve společných zdrojích inspirace, a zejména od paralel, které opravdu vycházejí z přimého, hlubokého, jednoznačného a doložitelného vlivu Chestertonova díla na Lewiso myšlení.

Literatura:

AESCHLIMAN, Michael (1983): The Restitution of Man. C. S. Lewis and the Case against Scientism, Grand Rapids: Eerdmans

BOYD, Ian (1991): Chesterton and C. S. Lewis, The Chesterton Review 17 (3 a 4): 303-311

BOYD, lan (1989): Sacramental Mysticism in Chesterton and Lewis, CSL. The Bulletin of the New York C. S. Lewis Society $21(1): 1-3$

CARPENTER, Humphrey (1979): The Inklings, Boston: Hougton Miffin Co.

CHESTERTON, Gilbert Keith (1955): The Everlasting Man, Garden City: Image Books

DANIELS, Jerry (1981): Lewis and Chesterton: the Smell of Dew and Thunder. CSL. The Bulletin of the New York C. S. Lewis Society 12 (11): $1-16$

KRANZ, Gisbert (1991): Affinities in Lewis and Chesterton, The Chesterton Review 17 (3 a 4): 323- 337

LEWIS, Clive Staples (1962): Anthology of George MacDonald, Garden City: Doubleday

EWIS, Clive Staples (1991): A Defense of Chesterton, The Chesterton Review 17 (3 a 4): 298 - 301

LEWIS, Clive Staples (1970): God in the Dock, Grand Rapids: Eerdmans

LEWIS, Clive Staples (1988): Letters, London: Fount Paperbacks

LEWIS, Clive Staples (1992): Pilgrim's Regress, Grand Rapids: Eerdmans

LEWIS, Clive Staples (1994): Zaskočen radostí, Praha: ČKA

MACDONALD, Michael a TADIE, Andrew, ed. (1989): G. K. Chesterton and C. S. Lewis: The Riddle of Joy, Grand Rapids: Eerdmans

MACKEY Aidan (1998): The Christian Influence of G. K. Chesterton on C. S. Lewis, in: WALKER, Andrew a PATRICK, James, ed., Rumours of Heaven. Essays in celebration of C. S. Lewis, Guilford: Eagle, s. 68-82 MARTIN, J., (1978): Chesterton and Lewis: The Necessary Angels, CSL. The Bulletin of the New York C. S. Lewis Society 9 (1)

MILWARD, Peter (2001): From G. K. Chesterton to C. S. Lewis, in: GRAHAM, David ed., We Remember C. S. Lewis, Nashville: Broadman and Holman Publishers, s. $65-69$

PATRICK, James (1991): Reason in Chesterton and Lewis, The Chesterton Review 17 ( 3 a 4 ): 349 - 355

PETERS, Thomas (1997): Simply C. S. Lewis, Wheaton: Crossway Books

STONE DALE, Alzina (1988): C. S. Lewis and Gilbert Keith Chesterton: Conservative Defendants as Critics, in EDWARDS, Bruce, ed., The Taste of the Pineapple. Essays on C. S. Lewis, Bowling Green: State University Popular Press, s. 206-218 
WALCZUK, Anna (1991): The Permanent in Lewis and Chesterton, The Chesterton Review 17 (3 a 4): 313-32

\section{Jan Lukavec}

\section{Chesterton jako prorok vědy?}

\section{Abstract}

In my book about Chesterton (Fanatic, prophet or clown? G.K. Chesterton and his exponents) I distinguished three contradictory aspects of Chesterton's work: polysemiotics versus ideological monosemiotics, movement towards negation of reality and order versus movement towards affirmation of reality and order, anthropological particularism versus universalism. This is why Chesterton could be understood as a conservative as well as a revolutionary, as a defender of universal human rights as well as a chauvinist, as a specialist in semiotics and heterogeneous interpretations as well as an ideologue constantly reiterating the same statement. Also in Chesterton's relation towards science we can find ambiguous attitudes, for example towards supernatural phenomena. In most of his works, miracles really take place. Chesterton perceived openness to miracles as a sign of wisdom, but in his Father Brown stories, the main hero solves all the crimes simply with the help of his common sense, the belief in miracles being characteristic of superstitious materialists and charlatans. This and other paradoxes are also reflected in Chesterton's reception among the Czech scientific community. Astronomer Jiří Grygar, a leading representative of Sisyfos, the Czech Sceptics' Club, understands Chesterton as somebody who perfectly discriminates between faith and superstition, and between science and pseudoscience. On the other hand, biologist A. Markoš and geologist V. Cillek, disciples of the Czech philosopher and biologist Z. Neubaver, regard Chesterton as a great opponent of scientism, the Sisyfos Club being a paradigm of this approach. 
Žijeme v době, kdy se obecně mluví a často diskutuje o velkém odcizení mezi přírodním a společenskými vědami a také o tom, že věda jako taková se stále více vzdaluje obyčejnému světu a také světu umění. Podle Milana Kundery byl Johann W. Goethe, který jako mladý muž ještě studuje alchymii a později je jedním z prvních moderních vědců, posledním spisovatelem, který drži v podivuhodné rovnováze tyto dva odlišné přistupy ke skutečnosti. Podle Kundery pak už Evropa takovouto rovnováhu nikdy nepozná.

V tomto kontextu Chesterton vystupuje, aspoň na první pohled, jako typický představitel onoho pogoethovského rozštěpení vědy a umění, jako nemilosrdný kritik č dokonce rozhodný neprítel vědy jako nástroje jednostranné a reduktivní racionality. Nejdramatičtěji je toto pojetí vědy zobrazeno v Chestertonově knize Koule a křiž, na jejímž konci se hrdina i se svým druhem ocitá v blázinci ovládaném šíleným vědcem: „V té chvíli se nad ním vztyčila a zalila ho vlna celé té hrưzy vědeckého uvěznění, jež dovede člověka nejen zbavit svobody" (CHESTERTON, Gilbert Keith,1923, s. 198). Na druhou stanu je ale nutné hned citovat jiné Chestertonovy výroky, které takový jednostranný obraz korigují. Chesterton např́klad zdůrazňoval: „Nikdy jsem neřekl ani slovo proti významným mužům vědy. Stěžuji si jenom na mlhavou filosofickou popularizaci vědy, jež se vědecky pouze tváří, ale ve skutečnosti je jen nechutným novým náboženstvím (CHESTERTON, Gilbert Keith, 2007). Vưči vědě je také poměrně vstřícný jeho výrok, že "vědec se nesnaží nic dokázat; snaži se jen zjistit, co se dokáže dokázat samo" (CHESTERTON, Gilbert Keith, 2007, s. 81), který ve své knize O vědě a viŕe cituje astronom Jiř Grygar. Chestertononův text Etika říše pohádek z Ortodoxie zařadil americký matematik Martin Gardner do prestižní antologie „velkých esejí o vědě”. V Americe vyšla roku 1986 kniha benediktinského kněze a filozofa prírodních věd Stanleyho Jakiho s názvem Ches terton, prorok vědy, v niž autor piše Chesterton kritizoval vědu (nejen v případě eugeniky) většinou oprávněně; podle něj ji tak chránil před tím, aby se proměnila v otupujíci monstrum. (JAKI, Stanley, 1986, s. 119). Přesnější než tvrzení, že Chesterton bojova proti vědě, se tedy ukazuje spiś výrok, že bojoval proti tomu, co dnes nazýváme scientismus, tedy proti přesvědčení, že - slovy I.M. Havla (HAVEL, Ivan M., 1992) - „věda odhaluje pravdu; pravda je jediná; věda jediná odhaluje pravdu; pravda je tedy to, co odhaluje věda”, nebo že relevantní jsou pouze „pravdy vědecké a všechno mimo ně je jen mámení a klam" (slovy biologa a filozofa prírodních věd Stanislava Komárka).

Proti takovémuto scientismu ovšem Chesterton bojoval velmi vytrvale a sveřepě. V detektivních povídkách o otci Brownovi se vyskytují karikatury vědcủ, nad nimiž kněz Brown pravidelně vítězí silou svého přirozeného rozumu, zatímco oni vědci, jež Chesterton nazývá „materialisté”, jsou odhalováni jako iracionalismu propadlé by tosti. Brown jim v závěru jedné takové povídky adresuje větu „Všichni jste prohlašovali, že jste zapřisáhlí materialisté, ve skutečnosti však balancujete na samém okraji víry víry v cokoli" (CHESTERTON, Gilbert Keith, 1989, s. 162), což je jedna z verzí výroku, který se Chestertonovi připisuje a který u nás často cituje zmiňovaný Jiři Grygar: „Od té doby, co lidé přestali věřit v Boha, jsou ochotni uvěřit čemukoli”. Oni materialisté přitom otci Brownovi nejprve předhazují, že „věri v poustevníky, kteří si vyčaruji ze vzduchu krokodýla, přeplují na něm řeku a pak krokodýlovi řeknou, aby chcípl, a on poslechne. Věrí na svaté, kteři pověsí svơj plášť na slunečni paprsek, a zase jiní přeplují na takovém paprsku Atlantik. Př́rodní zákony patrně nebere v úvahu" (CHESTERTON, Gilbert Keith, 1989, s. 144). Muž, který je zastáncem podle Chestertona nebezpečného východního mysticismu a kterého vzápětí Brown odhalí jako vraha, dokonce knězi přímo říká: „Vy byste se měl zastávat všeho, čemu hlupáci řikaji pověry, všech těch babských povídaček o talismanech a čárách. To je vaše povinnost, všemu věritt". Otec Brown mu nato ovšem poněkud překvapivě odpoví, že je agnostik (CHESTERTON, Gilbert Keith, 1992, s. 88). Zde připomeňme, že Chesterton se jinak ve svých knihách celý svưj život zastával zázraků, nejen v tom smyslu, že zázrakem je i ta nejobyčejnější a nejvšednější věc, ale skutečně i jevů vybočujicích z přirozeného řádu. Právě ve zmiňované Etice ří̌̌e pohádek Chesterton kupříkladu vytýká materialistickému profesorovi, že je "sentimentální, když mu jabloňové květy "jakousi temnou asociaci” připomínají jablka; Chesterton totiž nechápe, proč by jabloň nemohla mít rudé tulipány" (CHESTERTON, Gilbert Keith, 2000, s. 45). Jeden z prvních Chestertonových životopisců, katolický kněz Joseph de Tonquédec, dokonce za tuto "libovolnost" Chestertona kritizoval s tím, že Bůh sice může stvořit, co chce, ale stvořená bytost má své zákony a jabloň od př́rody není utvářena $k$ nošení tulipánů (MAUROIS, André, 1937, s. 135). Výskyt nadpřirozeného jevu a reakce na něj jsou základem Chestertonovy hry Kouzlo, a v knize o svatém Františkovi z Assisi se Chesterton coby ctitel středověku proti moderním skeptikům samozřejmě horlivě zastával všech zázraků onoho světce i nadpřirozených jevů obecně: pro teistu je stejně rozumné věřit v zázraky, jako pro ateistu v ně nevěřit (CHESTERTON, Gilbert Keith, 1993, s. 120). Onen zmíněný "agnosticismus” se tedy týkal jen fikčniho světa Chestertonových detektivek, kam Chesterton zázraky, magii ani cokoli ezoterického prostě vpustit nechtěl, asi nejen proto, že by to odporovalo pravidlům žánru, jak je kodifikoval jeho prítel Ronald Knox: druhé z nich říká, že „všechny nadpřirozené nebo neprirozené faktory jsou zcela vyloučeny". Pokud by na jabloni kvetly tulipány a podobně, bylo by velmi obtižné někoho čistě racionálně na základě důkazů usvědčit. Chestertonovi jde v jeho detektivkách ovšem právě o důkaz toho, že zdravý rozum otce Browna se v praxi ukazuje jako jediný nesoucí konkrétní a nezpochybnitelné výsledky. S odkazem na Tonquédeca můžeme samozřejmě o Chestertonově tvorbě říct, že i on má jako spisovatel právo nato tvořit odlišné světy, z nichž každý má své vlastní zákony, jenomže u Chestertona se hranice mezi fikcí a nonfikcí většinou úplně stírá (jak o tom ještě dnes uslyšíme), jeho eseje plynule přecházejí v povídky a obráceně, a otec Brown většinou vystupuje jako postava věrně tlumočíí Chestertonovy názory. $V$ tomto smyslu tedy vidím drobný rozpor $v$ tom, že zatímco ve většině Chestertonových beletrických i nebeletristických děl je schopnost otevř́t se existenci nadpřirozeného jevu znakem skutečné moudrosti, v Chestertonových detektivkách naopak víra v zázraky charakterizuje materialisty a šarlatány, od nichž se Brown odlišuje tím, že on jediný si vždy vystačí se svým střídmým, věcným, nebojím se 
řict v dobrém slova smyslu vědeckým přistupem a zázraky nepotřebuje. Samozřejmě je $\checkmark$ pozadí Chestertonovo přesvědčení, že Brownưv rozum dobře funguje právě proto, že není odtržen od víry. $\vee$ tomto smyslu Chestertonovy detektivní povídky obsahuji určitou metafyzickou rovinu: zločiny pro Browna nejsou ani tak přestupky proti lidským zákonům, jako hlavně hříchy vedoucími k zatracení; tvář jednoho zločince je tedy popsána jako „obličej dáblův” (CHESTERTON, Gilbert Keith, 1985, s. 267), jindy vrahovu tvár charakterizuje "dábelské šilháni" (CHESTERTON, Gilbert Keith, 1985, s. 40). Dokonce i na magii v jistém smyslu dochází, když Brown s odkazy na katolickou církev naznačuje, že přece jen existuje magie, ovšem magie bílá, což ovšem podle něj ani materialisté an vyznavači esoteriky netuši (CHESTERTON, Gilbert Keith, 1992, 95).

Mnohem častěji ovšem Chesterton spojoval magii ne s náboženstvím, ale právě s vědou (tedy onou nepravou, scientistickou): „vědecká pověra nebo magická pověra, to máte $z$ deště pod okap. Obojí nakonec dělá z lidí paralytiky, kteří nemohou hnout vlastní nohou ani rukou, ani zachránit svưj život nebo duši" (CHESTERTON, Gilbert Keith, 1974) - to je výrok z Chestertonovy detektivky, který v doslovu ke knize Jsme téměř 100\% šimpanzi? nedávno souhlasně citoval teoretický biolog Anton Markoš. Ve svých článcích Chesterton toto pojetí rozvíjel; magie a scientistická věda, zvláště medicína, jsou si podle něj v jednom ohledu velmi podobné, totiž v tom, že jim nejde o pravdu a čisté poznání, ale o to, aby dosáhly rychlých a praktických výsledkư, a aby byly držiteli moci. Chesterton se přitom odvolával třeba na katolického historika Ch. Dawsona, jehož pojetí bylo shodné (DAWSON, Christopher, 1947, s. 170), ale o spojitosti vědy a magie v Chestertonově době psali i mnozí další autoři, jednak další křestansky orientovani (jako C.S. Lewis)리 ale také filozofové (jako Edwin Burrt)² a kulturní antropologové. Kupríkladu podle B. Malinowského byla magie "vědou primitivních společnosti” (MURPHY, Robert, 1999, s. 181), a už před tím slavný antropolog a hlavní představitel evolucionismu James G. Frazer (1854 -1941) tvrdil, že „ mezi magickou a vědeckou koncepc světa je těsná analogie. V obou prípadech se vychází z naprosto pravidelné a spolehlivè

1) Také C.S. Lewis tvrdil cosi podobného: „Opravdové magické a opravdové vědecké úsill jsou dvojčata. Prvníbylo nemocnéa zemřelo, druhésilnéa prospivalo. Ale byla to dvojčata zrozená ze stejného impulsu... Je tu něco, co sjednocuje magii a užitou vědu té doby a zá roveňje isoluje od "moudrosti" dávnějšich dob. Pro moudrémuže dávnověku bylo hlavním problémem, jak smirit duši a venkovni skutečnost - a řešením bylo vědění, sebeukázněni a ctnost. Pro magii a užitou vědu byl problém postaven jinak - jak svět podř́dit vlastním přáním. Řešení poskytla technika. Kvưli které magie i věda začala dělat věci, do té doby považované za nechutné a málo zbožnéjako je vykopávání mrtvol a jejich hanobeni". [cit. 2009-5-1]. Dostupnéz http://www.sustainable.cz/neprijemnesousedstvivedy.htm 2) Šlo především o jeho knihu Metafyzické základy moderní vědy z roku 1924, v niž autor mimo jiné upozorňoval na velký vliv hermetických myšlenek na vznik moderni vědy. následnosti jevư, určené neměnnými zákony (FRAZER, James George, 1994, s. 49). Hlavní, ale zato osudová chyba magie spočívá podle Frazera v chybné interpretaci pod staty oněch zvláštních zákonů, které tuto následnost rídí. Zatímco Frazer se do jiste míry snažil srovnáváním s vědou najít na magii něco pozitivního a aspoň trochu ji ospravedlnit, Chesterton naopak (scientistickou) vědu prířazením k magii zavrhuje ${ }^{3}$. Chesterton a další tak anticipoval pozdější slavné, ale i hodně kritizované teze britské historičky Frances Yatesové (PEARCYOVÁ, Nancy R. - THAXTON, Charles B., 1997, s. 43n), která byla označena dokonce za zakladatelku nového paradigmatu ve vnímání hermetismu jako integrální součásti renesanční kultury a faktoru, bez kterého by novověká věda vů bec nevnikla, což dnes v Čechách vytrvale prohlašuje také Zdeněk Neubauer ${ }^{4}$. Chesterton ve stejné době jako Burtt poukazoval na staré spojení mezi vědou a magií, které má jakýsi skrytý a historicky velmi zajímavý smysl"5, ale onen neubauerovský smysl tomu zřejmě nedával. Zato ale svojí kritikou spojení moci a medicíny značně předběhl Neu bauerova žáka S. Komárka, který nedávno kritice, jak on říká, „medicínsko-průmyslového komplexu" věnoval knihu Spasení těla : moc, nemoc a psychosomatika (KOMÁREK, Stanislav, 2005). Trochu provokativně bychom se však mohli ptát, jestli otec Brown postupujicí stroze racionální metodou vedoucí vždy ke konkrétnímu cíli, Brown jako kněz disponující nemalou duchovní mocí, se onomu vědci trochu nepodobá ${ }^{6}$.

Nyní ještě krátce $k$ dalšímu aktuálnímu tématu, danému loňským výročím Ch. Darwina. $V$ době, kdy to ještě vưbec nebylo mezi katolíky obvyklé, Chesterton připouštěl, že se lidské tělo vyvinulo ze zviřat a o Darwinovi se vyjadřoval s respektem. Darwinưv agnosticismus ovšem dával do kontrastu s dogmatismem darwinistů, kterým ostatně váž ně předpovídal brzké vyhynutí, jako zřejmě většina tehdejších katolíků (CHESTERTON,

3) Podobné inverze mezi Frazerem a Chestertonem nacházíme i jinde: pokud Frazer poukazoval na analogie mezi zpưsobem myšlení prírodnich národů a myšlením mnoha jeho současniků vyznávajících krestáanskou viru, bylo to pro něj znameníjejí zaostalosti: křest'anství, které odmítal jako něco zcela falešného, podle něj samo náleží k překonaným stádím vývoje lidstva. (BUDIL, Ivo T., 2001, s. 514) Oproti tomu když Chesterton prohla šoval, co má (i on sám - už v tom je ve srovnánís Frazerem velký rozdill) s „divochy" společného, je to pro něj prostředek obrany "divochư", ale predevším obrany náboženské viry (LUKAVEC, Jan, 2008, s. 83).

4) Podobně piše Markoš, že nemůže „opomenout přesahy s oblasti mýtů, magie, hermetismu, gnose, umění, protože se z nívěda zrodila, prímo s ní hraničía zưstává pro některé vědecké směry i nadile zdrojem inspirace". (MARKOŠ, Anton, 2003, s. 40)

5) [cit. 2009-5-1]. Dostupnéz http://gkch.wordpress.com/2009/03/02/esej-x-o-virach/ 6) Př́ipomeňme, že v diskuzi o scientismu, která reagovala na výše citovanou definic I.M. Havla, několikrát zazněly hlasy, že právě detektiv poznává "pravdu" metodou podobnou té vědecké, nebo př́mo totožnou (např. SCHREIBER, Vratislav, 1992, s. 168). 
Gilbert Keith, 1927, s. 45). Polemizoval ovšem i se samotným principem přírodního výběru. Když se například dočetl v nějakém pojednáni o darwinismu, že „Příroda vybírá jedince, kteři variují nejúspěšnějším směrem”, komentoval to sarkasticky: „když lidé ve starých náboženstvích řikali, že Bůh si vyvolil národ a povolal proroka, alespoň tím něco mysleli a to, co říkali, mysleli vážně". Jenže když takto mluví darwinisté, jde podle Chestertona o kruhem dokazovanou banalitu", která je obklopena mytologickým mračnem. To mưžeme srovnat s nedávným textem S. Komárka, který srovnával otázky a pravděpodobné odpovědi na Karlově universitě A.D. 1400 a roku 2007: Proč jsou labutě bílé? Středověká odpověd’: protože je Stvořitel bílými míti chtěl. A proč tomu tak chtěl? Inu nevíme, ale Stvořitel ve své moudrosti jistě věděl, co činí. A nyn odpovědi soudobé vědy: Proč jsou labutě bílé? Protože se bílá barva v selekčním procesu prosadila. A proč se prosadila? To nevíme, ale protože se prosadila, nějakou výhodu vzhledem k reprodukci přinášet musela - Komárek pasáž ironicky uzavírá tím, že z toho srovnání je patrné, jak „radikálně se podařilo se středověkým obskurantismem zatočit”. (KOMÁREK, Stanislav, 2008) Nerad bych ale chválu na předvídavost Chestertona a vtipnost Komárka přeháněl, protože tady soudobým biologům Komárek křivdí. Od zoologa F. Šusty z pražské ZOO se mi dostalo vysvětlení, že labutě měly svoje pưvodní rozšířeni v Rusku. Tam, odkud' labut' pochází, je skoro polovinu roku sníh (takže bilá barva jí kryje) a teoreticky to může odrážet prílišné záření v létě (pro vnitrozemí Sibiře je typická velmi studená zima a hodně teplé léto).

Chesterton má dnes co říci také k odcizení mezi přírodními a společenským vědami, které jsem už zmiňoval, dobře například věděl, že „týž chladný a neúčastny duch, který vede $k$ úspěchu při studiu astronomie nebo botaniky, vede $k$ pohromě př studiu mytologie nebo lidských počátkủ... Chce-li někdo poznat původ lidské společnosti, poznat, čím společnost skutečně je, at nechodí do Britského musea; at' jde do společnosti" (CHESTERTON, Gilbert Keith, 1915, 128n)- to je zase citát, který si z Chestertona vybral ředitel Geologického ústavu a spisovatel Václav Cílek do knihy Makom.

Poměrně prozíravě Chesterton ve své době hodnotil vztah náboženstv' a vědy, když tvrdil, že se „v devatenáctém století soukromé biblické doktríny a předčasné prírodovědecké teorie střetly $v$ zuřivém zápase dvou netrpělivých ignorantských stran, který je bohužel známý jako spor mezi vědou a náboženstvím" (CHESTERTON Gilbert Keith, 2007, s. 82). V tom se zcela shoduje třeba se současnou antropoložkou Merryl Daviesovou, která napsala, že jsme se stali „rukojmími dvou krajních názorü”, křestanského a vědeckého fundamentalismu (DAVIESOVÁ, Merryl, 2002, 10n). Hned ale musím dodat, že v Chestertonově době bez výjimky snad všichni křestanšstí autoř odmítali, že by existoval spor mezi vírou a skutečnou vědou - klíčový je ovšem prívlastek "skutečný”, protože o darwinismu prostě prohlásili, že to žádná skutečná věda není, a v tom se Chesterton nelišil (NOVOTNÝ, Josef, 1920; VRCHOVECKÝ, Josef, 1934). Podobněi jeho odpor ke scientismu odpovídal v jistém smyslu „duchu doby": podle historika Johna Burrowa „mluvit o omezeních vědecké metody začalo být ke konci 19. století projevem intelektuální vyspělosti a zároveň i klišé." (BURROW, John Wyon, 2003, 74n) Že ovšem nešlo u Chestertona čistě o projev módy, ale že jeho myšlenky v této oblast snad mají trvalejši platnost ukazuje to, jak široce ho dnes cituji i čeští prírodní vědci.

Tak se dostáváme k recepci Chestertona v současné české vědecké komunitě: na jedné straně mezi tyto recipienty patři J. Grygar, na straně druhé Anton Markoš, Václav Cílek, či Pavel Holásek7. Holásek je autorem darwinovsky znějicího titulu O pưvodu druhủ. Pohádková biologie podle G. K. Chestertona. V tomto spisu Holásek předestřel vlastní originální koncepci biologie, v niž se snaží spojovat myšlenkový svět Chestertona s vizemi Z. Neubauera. A právě k Neubauerovi se Markoš, Cílek i Holásek hlásí jako ke svému učiteli. Můžeme tak konstatovat, že podobně, jako se v meziválečném obdob k Chestertonovi hlásili liberálové, komunisté a katolíci, kteří proti sobě navzájem bojovali (což ovšem koresponovalo s polytendenčností a vniřním napětím Chestertonova vlastního myšlení (LUKAVEC, Jan, 2008), také dnes je Chesterton oblíbeným autorem mezi lidmi patřícími k odlišným a někdy až nesmiřitelným táborům. Grygar totiž patř k čelným představitelům Českého klubu skeptiků Sisyfos a vědci z okruhu Z. Neubauera jsou pro něj pouhými pavědci, pročež institucím či periodikưm ${ }^{8}$, kde se angažuji, rozdal již četné bludné balvany za „matení české veřejnosti a rozvoj blátivého způsobu myšlení"; neubauerovci naoplátku Sysifos pokládají za typicky scientistickou organizaci甲 a třeba Neubauer právě aktivity klubu Sysifos označil zdánlivě paradoxně za iracionální Tomu odpovídá jakási dvouhlasá recepce Chestertona, která ovšem i v této věci odpovídá vnitřní protikladnosti Chestertonova díla: jestliže pro Grygara je Chesterton tím, kdo dokáže dobře vystihnout rozdíl mezi vírou a pověrou, a mezi vědou a pavědou, pro Markoše a další "neubauerovce” je Chesterton kritikem scientismu, který stále upozorňuje vědce nato, že by neměli príliš uspěchaně své teorie pokládat za nezpochybnitelné prav dy. Věc je přitom o to komplikovanější, že Neubauer s Grygarem přísluší k téže (katolické) církvi jako Chesterton, i když v pojetí víry se samozřejmě neshodnou, jak ukázala jejich vzájemná debata, v niž Neubauer označil Grygarovo pojetí vztahu křestanstv a vědy za "racionální teologii 19. stoleti”, což bylo myšleno hodně pejorativně ${ }^{10}$. Grygarův spolek Sysifos pritom mezi okultní, ezoterické a paranormální jevy zahrnuje (podle svých oficiálních webových stránek) např. keltománii, numerologii, tzv. ufologii, téma mimozemštanů, proutkaření, pseudohistorii, kreacionismus, ale i zázraky a posmrtny život. Grygar jako konzervativní katolík přirozeně na zázraky (jako Ježíšovo zmrtvých-

7) Jde o prvniho absolventa Katedry filosofie a dějin prírodních věd Přrrodovědeckéfakulty UK, jižje právě Markoš vedouci.

8) jako časopis Vesmír a Svobodná universita

9) Ovšem sám sebe málokdo označuje za scientistu, pro Poppera jím byl Toynbee a pro

Adorna sám Popper (MOURAL, Josef, 1999, s. 16).

10) [cit. 2009-5-1]. Dostupnéz http://astrolot.cz/mimo/grygarvsneubauer.htm 
vstání a věčný život, což jsou články víry) věří, jak výslovně potvrdil, ale asi ne, když překroči práh klubu Sysifos. Je to snad trochu analogické tomu, že v detektivním žánru Chesterton zázraky neuznává, $v$ žánru hagiografie i jiných ano (přitom agnosticimus Chestertonových detektivek má k sysifovskému skepticismu v Grygarově provedení poměrně blizko). Podobných přechodů mezi rưznými typy vědění ovšem není prost asi nikdo a snad by se tento pohyb např́ič odlišnými kognitivními vrstvami dal popsat pomoci výroku Goetha, podle něhož „bádajíce o prírodě jsme panteisty, když básníme, jsme polyteisty, a mravně monoteisty"11.

Když znovu zaznělo Goethovo jméno, rád bych se ted' ještě jednou vrátil k onomu úvodnímu výroku M. Kundery o posledním integrujicím spisovateli a ještě více jej zrelativizoval. Je totiž nutné doplnit, že Chesterton sice neobjevil žádnou novou kost jako Goethe, ani nenapsal spis o barvách, ale samotná príroda i barvy v jeho knihách hrají důležitou roli12. $\vee$ jeho prózách navíc nevystupuji vědci jen jako negativní postavy: připomeňme naopak sympatického antropologa profesora Chadda z Klubu podivných živností, kterỳ chce dokázat svoji teorii komunikace u Zuluů, a proto přerušuje verbální komunikaci a dorozumívá se jen posunky. Zvláště pak musíme vyzdvihnout postavu básníka Doriana Wimpola z Létajíci hospody. To sice není vědec v prísném slova smyslu, ale jeho básně, ktere naplnil „hypotetickou psychologii veškerých stvoření zoologických zahrad”, evidentně směřovaly do oblasti biologie (či spiše etologie) a u čtenář se proto vždy nesetkávaly s pochopením. Když totiž čtenář hledal běžnou salónní lyriku a přišel na verše nadepsane Pouštni piseň lásky a začínající slovy "Její hlava k hvězdám trčí, její hrb se pýchou dme”, mohl být takovým holdem dámě poděšen; aspoň dokud si neuvědomil, že všichni hrdinové této idylické skladby jsou velbloudi" (CHESTERTON, Gilbert Keith، 1985, s. 258). Chestertonův básník se tak zabýval vnitřními světy četných tvorů, zvláště těch, na „které člověk zapomíná”, což koresponodovalo s koncepcemi tzv. umweltu - „žitého světa”, které v téže době rozvijel německý biolog a Chestertonův současník Jakob J. von Uexküll $(1864-1944)^{13} . V$ této souvislosti není marné připomenout koncepci francouzského filozofa a historika vědy Michela Serrese, podle něhož se v každé epoše vyskytují mezi exaktními vědami a uměním jisté podobnosti a rezonance ${ }^{14}$. Úzká souvislost vědeckých

11) Snad i některé "rozpory" $v$ Chestertonově politickém myšlení by se daly popsat pomoc takovýchto přechodů; podobně to dělá i současnýslovenský politolog Eduard Chmelár, kterýo o sobě tvrdi: „, v rovine politiky som liberál, v ekonomike socialista a v morálke taký konzervatívec, že by sa za mňa nemuselo hanbit hádam ani KDH". ([cit. 2009-5-1]. Dostupne $z$ http://sudor.blog.sme.sk/c/61466/Eduard-Chmelar-Nie-som-lavicovy-intelektual.html). 12) Někdy se dokonce mluvío sakramentálním mysticismu, kterýse u Chestertona rozširuje na celou prírodu.

13) Vůbec ne náhodou jeho odkaz u nás propagujíS. Komárek a Markoš.

14) Onen Kunderưv výrok miostatně prípomněla četba nedávného vynikajiciho kunderovského teorií a uměleckých děl v jednotlivých epochách by se podle něj dala přirovnat k fenoménu, který německá romantika označovala jako Zeitgeist (duch doby), tedy jakési podvědomé souznění filosofie, vědy a umění. Při charakterizaci epochy Informačního věku 20. století se Serres mimochodem odvolává na román Muž bez vlastností od Roberta Mu sila, který byl Chestertonovým obdivovatelem a který tento román psal právě pod Chestertonovým vlivem (LUKAVEC, Jan, 2008, s. 65). Tématem této epochy je podle Serrese náhodné, neurčité, nedefinovatelné; oblak, šum, chaos, z něhož se vynořuje zpráva, informace, řád, svět. Jak už jsem se ale snažil ukázat ve své knize, jedním z hlavních témat procházejících Chestertonovým dílem je téma civilizace a rádu jako něčeho, co se každou chvíli mưže znovu a znovu zanořit zpátky do chaosu (LUKAVEC, Jan, 2008, s. 19). V tomto serresovskem smyslu je možné směle prohlásit, že Chestertonovo dílo souznělo i se soudobou vědou. A když si vzpomeneme na zmiňovaného básníka Wimpola, je možné jít ještě dál a rozšírit kategorii toho, co všechno Chesterton anticipoval ${ }^{15}$ : třeba o dnes ohlašovanou „postmodernistickou vědu, která zahrnuje estetiku a kreativitu a zaměřuje se na rozpoznávání vnitřní hodnoty organismư", jak se píše v loňské knize Třetí kultura, již do češtiny překládal A. Markoš (BROCKMAN, John, 2008, s. 98n). Chesterton by takovou vědu, která se nezakládá na statistikách, ale na kvalitách, možná přivítal. Ale co se týká otce Browna, nedivil bych se, kdybyji odsoudil jako málo vědeckou a iracionální.

článku psychiatra C. Höschla ([cit. 2009-5-1]. Dostupné z http://www.hoschl.cz/files/3723_cz_Hoschl_Kundera_vLN.pdf), což také müže naznačovat, že s onou propastímezi uměním a vědou to nemusí být tak radikálni.

15) Několik př́kladů: Chestertonův obraz šilence jako člověka, který „pozbyl všeho kromě rozumu", tedy který neni bržděn smyslem pro humor, ani láskou, ani němými jisto tami zkušenosti a který je tím logičtějš̌́, že ztratil jisté zdravé city, dnes jakoby potvrzujívědci zabývajícíse vztahem emocía racionality: „Ztráta emocímůže být nečekaným zdrojem iracionálniho jednáni", napsal neurolog António Damasio, což slavný popula rizátor vědy Matt Ridley komentuje slovy: „Kdybychom neměli emoce, byli by z nás racionální idioti" (RIDLEY, Matt, 2000, s. 156). Např́klad pacient, jehož vyššínervové funkce byly "osvobozeny" od vlivu emocí, zcela podle Chestertonových predpovědí po celé hodiny srovnával výhody a nevýhody různých restauraci - a na večeři se nikdy nevypravil. - J. Grygar nedávno vysoce ocenil Chestertonovu aktuálnost pro astrono mii, protože dlouho před objevem reliktniho zářeni tvrdil, že "světlo bylo stvořeno už dávno před světelnými tělesy vesmíru". - Podle S. Jakiho Chesterton mimo jiné anticipoval Kuhnovu teorii vědeckých revoluci. - Podle Ch. Houswitschky Chesterton svým chápáním paradoxů jako nedillné součásti systémů, v jejichž rámci vnímáme a chápame svět, anticipoval matematického génia Kurta Gödela, známého z knihy Gödel, Es. cher, Bach. Gödel dokázal, že žádný systém nemůže být úplný a zároveň vnitřně kon zistentní (HOUSWITSCHKA, Christoph, 1996, 129). 


\section{iteratura}

BROCKMAN, John (2008): Treetí kultura : za hranice vědecké revoluce. Praha: Academia.

BUDIL, Ivo T. (2001): Za obzor Západu : proměny antropologického myšleni od Isidora ze Sevilly po Franze Boase. Praha: Triton.

BURROW, John Wyon (2003): Krize rozumu:europské myšleni 1848 - 1914. Brno: Centrum pro studium demokracie a kultury (CDK).

CILEK, Václav (2004): Makom: kniha mist. Praha: Dokořán.

DAVIESOVÁ, MerryI Wyn (2002): Darwin a fundamentalismus. Praha: Triton.

DAWSON, Christopher (1947): Pokrok a náboženstvi: historická úvaha. Praha: Universum.

FRAZER, James George (1994): Zlatá ratolest. Praha: Mladá fronta.

GAJDOŠOVÁ, Jana (2006): Hermés. Teorie komunikace a pojem struktury v díle Michela Serrese. Diplomovà práce obhajená na Filozoficke fakultě Masarykovy univerzity virně.

GARDNER, Martin (1985): The sacred beetle: and other great essays in science. Oxford: Oxford University Press. GRYGAR, Jiří (2001): O vědě a viře. Kostelni Vydří: Karmelitánské nakladatelstvi.

HAVEL, Ivan M. (1992): O scientismu. Vesmír Roč. 71, č. 2, s. 63.

HOLÁSEK, Pavel: O pưvodu druhủ. Pohádková biologie podle G. K. Chestertona. ([cit. 2009-5-1]. Dostupnè zhttp://pavel.holasek.sweb.cz/texty/chesterton.htm

HOUSWITSCHKA, Christoph (1996): Paradoxy and orthodoxy in Father Brown's conduct of investigation In: Inklings. Jahrbuch für Literatur und Ästhetik. Bd. 14.

JAKI, Stanley (1986): Chesterton, a seer of science. Urbana and Chicago: University of Illinois Press.

CHESTERTON, Gilbert Keith (1915): Heretikové. Stará Řišse na Moravě : A. L. Stř̌iž.

CHESTERTON, Gilbert Keith (1927): Nesmrtelný člověk. Praha: Václav Petr.

CHESTERTON, Gilbert Keith (1974): Pochybnosti otce Browna. Praha: Vyšehrad.

CHESTERTON, Gilbert Keith (1985): Napoleon z Notting Hillu; Létajici hospoda; Návrat Dona Quijota. Praha:

CHESTERTON, Gilbert Keith (1989): Modrý křiž. Praha: Vyšehrad.

CHESTERTON, Gilbert Keith (1992): OKř́dlená dýka a jiné príběhy otce Browna. Praha: JAN.

CHESTERTON, Gilbert Keith (1993): Svatý František z Assisi. Praha: Alverna.

CHESTERTON, Gilbert Keith (2000): Ortodoxie. Praha: Academia.

CHESTERTON, Gilbert Keith (2007): Moudrost a vtip G.K. Chestertona : paradoxy, aforismy a postřehy. Kostelni Vydří: Karmelitánské nakladatelství.

KLIKOVA, Alice - KLEISNER, Karel (2006): Umwelt: koncepce žitého světa Jakoba von Uexkülla. Červeny Kostelec: Pavel Mervart.

KOMÁREK, Stanislav (2005): Spasení těla: moc, nemoc a psychosomatika. Praha: Mladá fronta. KOMÁREK, Stanislav (2008): Přríroda a kultura : svět jevĩ a svět interpretací. Praha: Academia.

LUKAVEC, Jan (2008): Fanatik, prorok, či klaun?: G.K. Chesterton a jeho interpreti. Brno: Centrum pro studium demokracie a kultury (CDK).

MARKOŠ, Anton (2003): Tajemstvi hladiny: hermeneutika živého. Praha: Dokořán.

MARKOŠ, Anton (2006): Doslov, in: Marks, Jonathan: Jsme téměř 100\% šimpanzi?: lidoopi, lidé a geny. Praha: Academia.

MAUROIS, André (1937): Sr
MOURAL, Josef (1999): Scientismus. Osudy jednoho pojmu (u nás i v cizozemí). Kritický sborník Roč. 18 č. 4, S. 7-18.

MURPHY, Robert F. (1999): Úvod do kulturnía sociální antropologie. Praha: Sociologické nakladatelstvi. NOVOTNÝ, Josef (1920): Věda a viŕa o původu světta. Hradec Králové: Tiskové družstvo Adalbertinum. PEARCYOVA, Nancy R. - THAXTON, Charles B. (1997): Duše vědy : proměny ve vztahu vědy a náboženstvi. Praha: Návrat domů.

RIDLEY, Matt (2000): PƯvod ctnosti : o evolučnich základech a zákonitostech nesobeckého jednání člověka. Praha: Portál.

SCHREIBER, Vratislav (1992): K diskusi o scientismu = O staronové nálepce scientismu. Vesmír Roč. 71, č. 3, S. $168-169$.

VRCHOVECKÝ, Josef (1934): Věda a víra. Olomouc: Matice cyrilometodějská. 
Kateřina Šašková

\section{Asyrský korunní princ}

\section{Abstract}

There was no firm established succession rule in the Assyrian Empire, and the choice of successor depended only on the volition of the ruler who voted for one of his sons. Just during the life of his father, Assyrian crown prince was initiated into the various activities rela ted to control of the state in order to get up the obligations of the ruler. The prince was also firmly connected with the cultic sphere. His ritual purity and the right activities were in the hands of the foremost scholars of the Assyrian royal court.

Asyrský korunní princ byl hned po panovníkovi nejvýznamnější osobou v Asyrské říši. Byl předurčen k tomu, aby po smrti krále převzal vládu, do jejiž tajů byl zasvěcován ještě za otcova života, kdy byl pověřován významnými státnickými úkoly. Jeho budoucí role $\checkmark$ čele státu však nespočivala pouze $v$ tom, aby pečoval o hospodářskou prosperitu země, bránil její hranice proti nájezdníkům a rozšiřoval území Asýrie, ale měl se stát rovněž nejvyšším knězem státního boha Aššura, jehož byl asyrský panovník místodržitelem a zástupcem na zemi. Všechny tyto úkoly vyžadovaly, aby se korunním princem stal muž nejen tělesně zdatný, aby byl schopen zvládat útrapy častých válečných tažení, ale také muž moudrý a rozvážny. 


\section{Vyobrazení}

Na reliéfech či stélách je asyrský korunní princ nejčastěji zobrazován ve společnosti svého královského otce. Jeho oděv je honosnější než šat ostatních dvorských hodnostářu a jeho šperky se svým uměleckým zpracováním bliží šperkům panovníka. Typickým znakem, podle něhož lze asyrského korunního prince identifikovat, je zdobný diadém, z něhož vzadu splývají dvě stuhy zakončené třásněmi. ${ }^{1}$ Uvázáni tohoto diadému bylo zřejmě součástí oficiálního jmenovacího obřadu (viz SAA IX, s. 38 - pozn. 7) a samotny diadém pak měl signalizovat, že právě tento z králových synů byl vybrán bohy i panovníkem za budoucího krále. ${ }^{2}$ Právě od okamžiku, kdy mu byl udělen diadém, se stal následník trůnu druhým nejvýznamnějším mužem ve státě.

\section{Písemné prameny}

Vzhledem $\mathrm{k}$ důležitosti úřadu korunního prince se dochovalo poměrně velké množstvi písemných památek, které nám jeho postavu přibližují. Někteří panovníci v úvodu svých nápisů zdůvodňují, proč jejich otec zvolil právě je svým následníkem, a několika větam popisuji období před svým nástupem na trưn. Dalším pramenem jsou administrativní záznamy a právní dokumenty, v nichž se objevují nejrůznější následníkovi služebníci, případně zmínky o něm, $\mathrm{a}$, ačkoliv jen zrrídkakdy, jsou $v$ těchto textech projednávány i záležitosti týkající se samotného korunního prince. Výjimku tvoří smlouvy o následnictví, v nichž vladař slavnostně určuje svého nástupce a pod záštitou božstev si pro něho vymiňuje věrnost všech svých poddaných.

Nejméně zastoupenými zdroji informací jsou prorocké texty a dotazy k slu nečnímu bohu Šamašovi, v nichž se panovník táže na správnost určitého rozhodnutí, jež se týká korunního prince, nebo na to, zda daný hodnostář zachová jemu i jeho synov věrnost. Naopak nejpočetnější a také nejhodnotnějši skupinou pramenů co do výpovědní hodnoty jsou dopisy, jež si mezi sebou vyměňovali panovník s korunním princem, významnými státními hodnostáři a královskými učenci. Právě z těchto dopisư se dozvídáme o kompetencích panovníkova nástupce ve správě státu, o jeho roli v kultovních záležitostech, ale také o vztazích uvnitř královské rodiny, o výchově a péči o královské potomky.

1) Viz vyobrazení.

2) Kupřikladu v dopise králi Asaraddonovi píše Adad-šumu-usur následujicí: „Opásal jsi svého syna čelenkou a poveřil jej kralováním nad Asýrií, svého nejstarš́ho synajsi pozve dl k vádě v Babylóně. Prvního jsi postavil po své pravici, druhého po své levici." (AOAT $5 / 1$, text 129, r. 7-13, s. 102-105).

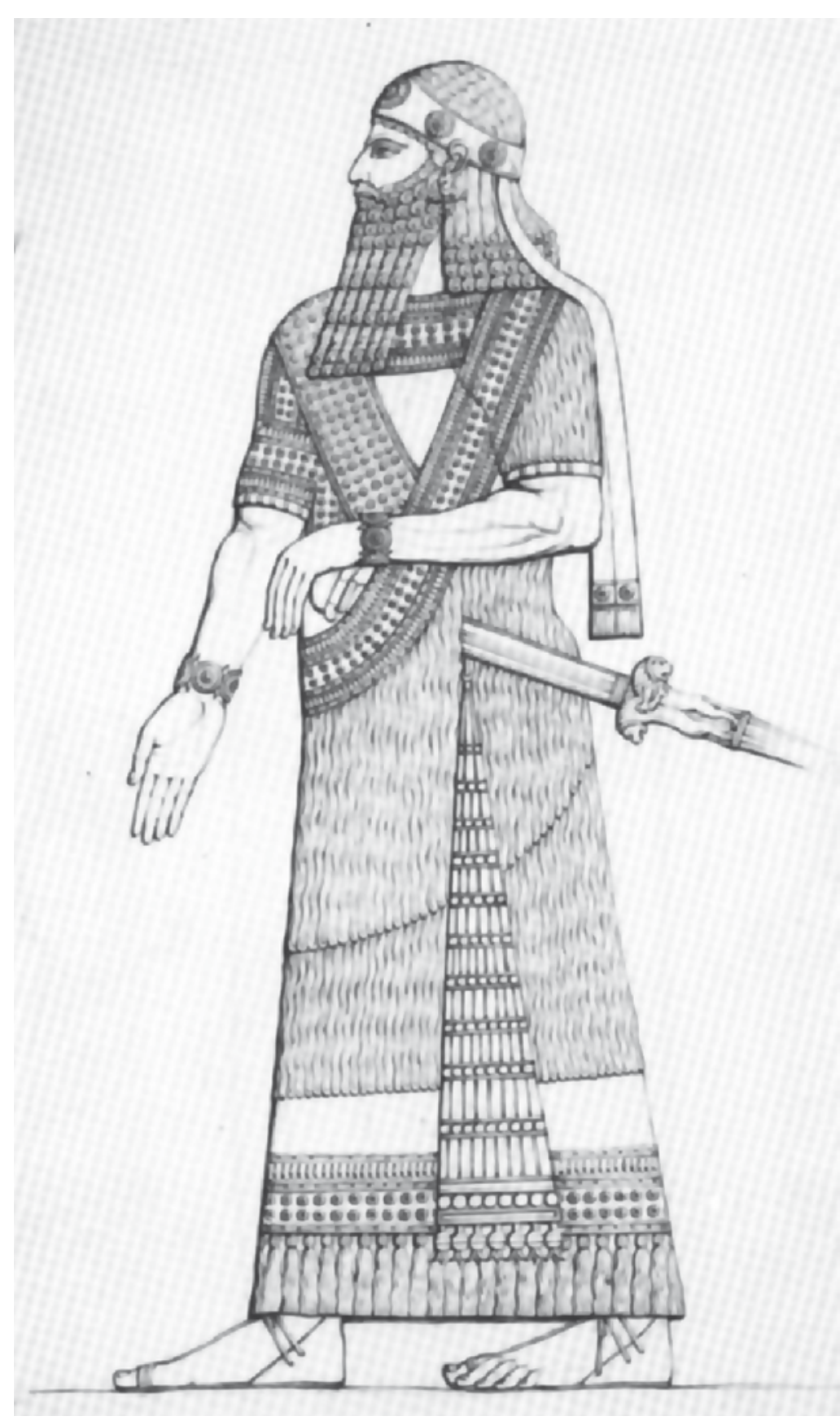

Obr. 1: Asyrský korunni princ (SAA II, s. 19) 
Značné obtiže nám však při posouzení role asyrského korunního prince v průběhu asyrských dějin činí časové rozložení dochovaných pramenů. Naprostá většina textů týkajících se následníka asyrského trůnu totiž pochází z novoasyrského období, přesněji z období vlády posledních panovníků, kteři pocházeli z takzvané dynastie Sargonovců. $Z$ toho důvodu se také následující text týká téměř výhradně tohoto období. Zajímavé je rovněž rozdělení pramenů do období vlády jednotlivých králů z tématického hlediska. Zatímco texty z doby Sargona Il. se týkaji spíše válečných akcí, v nichž operoval korunní princ Sinacherib jako hlava výzvědné služby na severní hranici země, texty z období vlády jeho vnuka Asarhaddona přibližují následníka Aššurbanipala spiše v kultické rovině.

Protože velká část pramenů pochází právě z období vlády krále Asarhaddona, dostáváme se kjedné zvláštnosti tohoto období, která je v asyrských dějinách ojedinělá. Aby Asarhaddon vyřešil odedávna komplikované a napjaté vztahy s Babylónií, která byla toho času pod nadvládou Asýrie, rozhodl se jmenovat svým nástupcem v čele Asýrie jednoho ze svých mladších synů, Aššurbanipala, zatímco jeho staršího bratra Šamaš-šuma-ukīna ustanovil následníkem babylónského trůnu. Asýrie tedy měla dva korunní prince, asyrského a babylónského. Ačkoliv byl Šamaš-šuma-ukīn svému mladšímu bratru podřazený, poměrně často se v textech objevuje po boku svého bratra. Aššurbanipal je v těchto textech titulován jako korunní princ, čímž se rozumí budoucí vládce celé říše, zatímco Šamaš-šuma-ukīn je nazývám korunním princem Babylónu. ${ }^{3}$

Oba dva korunní princové Asýrie jsou rovněž vyobrazeni na stéle svého otce Asarhaddona (viz Obr. 2), která byla nalezena v turecké lokalitě Zincirli, starověkém Sam’allu. ${ }^{4}$ Aššurbanipal a Šamaš-šuma-ukīn jsou vyobrazeni každý na jednom z bokư stély a oba mají na hlavách diadémy potvrzujíci jejich funkci korunního prince. Oba dva jsou také stejně vysocí, což by mohlo značit, že jsou si rovni. Avšak Aššurbanipalův šat i diadém jsou zdobnějši, a také je to on, kdo stojí ke svému otci čelem, kdežto Šamaš-šumaukīn stojí za Asarhaddonovými zády. Právě touto pozicí je vyjádřena Aššurbanipalova dominance nad jeho starším bratrem, korunním princem Babylónie (PORTER, Barbara Nevling, 2004, s. 267)

3) Napřkllad: Vydal jsem pokyny k obětem za Aššurbanipala, vel[kého korun]niho prince, za Šamaš-šuma-ukīna, korunniho prince Babylónu, za Šeru'u-ețerat, za Aššur-mukīn-paleiv a za Ašš[ur-et] lel-šamê-erșeti-muballissu." (SAA XIII, text 56, r. rev. 6 - 10, s. 52). 4) Viz PARPOLA, Simo, 2001, s. 15 a mapa 2 .

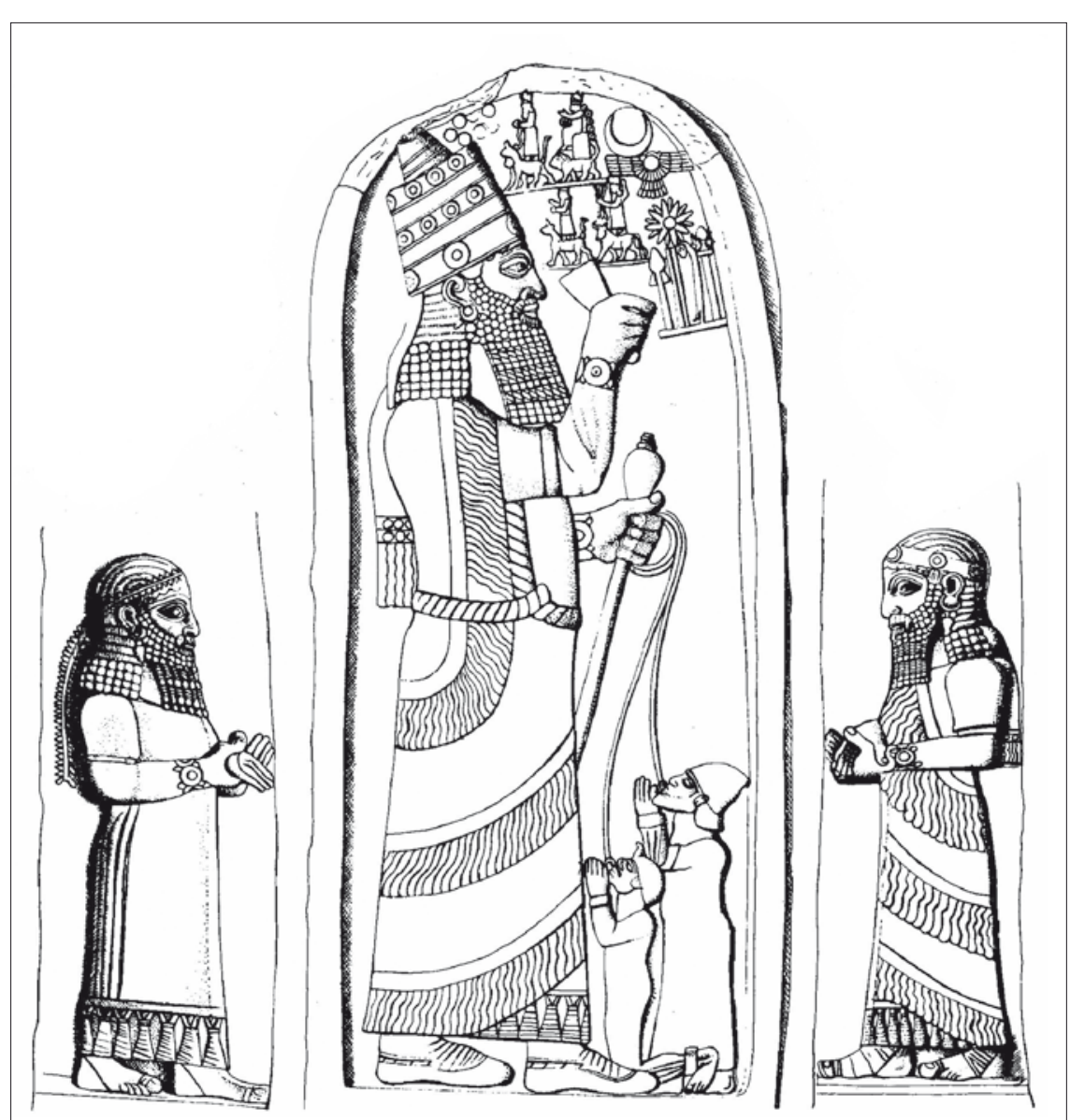

Obr. 2: Stéla ze Sam’allu (SAAS IX, s. 50)

\subsection{Titulatura korunního prince}

Problematická je rovněž otázka samotného titulu korunního prince. Asyrská titulatura totiž neměla pro následníka trůnu žádný speciální termín, a v pramenech je většinou nazýván jednoduše „králův syn”, ${ }_{1}^{5}$ což by ovšem mohlo teoreticky znamenat jakéhokoliv

5) Akkadskymāršarrillog DUMU-LUGAL (viz napřklad SAAI, texty 152 a 153, s. 121-123) log. A-MAN (viz napríklad SAA VI, text 39, s. 41-42, a SAA VI, text 85, s. 73- 74) nebo log. DUMU-MAN (viz napríklad SAA VI, text 37, s. 40, SAA VI, text 40, s. 42 - 43, nebo SAA VI, text 52, s. 51-52)). 
z králových synů. Sice se objevuji také honosnější tituly jako „velký králův syn” “6 „králův syn z Paláce následnictvii", 7 nebo spojení obou delších titulů - „velký králův syn z Paláce následnictví" 8 ale v dopisech, zprávách a administrativních textech se velmi často hovoři pouze o "královu synu", v naprosté většině bez uvedení vlastního jména. Je zřejmé, že $\checkmark$ textech tohoto druhu se jedná o korunního prince, protože ostatní královi potomc jsou naopak uváděni jen svým vlastním jménem, avšak není zcela jasné, zda tento zvyk platil i pro právní dokumenty a literární texty (viz SAA VI, s. XXVII).

\subsection{Korunní princ v osobních jménech}

O významu korunního prince svědčí rovněž fakt, že se jeho titul objevuje jako součást osobních jmen, v nichž je vyjádřena prosba o ochranu jeho osoby a je v nich zdůrazněno, že on stojí na svými bratry a že byl vybrán bohy, pod jejichž ochranou se nachází. Takovými jmény jsou např́klad Nabû-mār-šarri-ușur, ${ }^{9}$ Mār-šarri-aplu-ușur, ${ }^{10}$ Mār-šarri-belahhe, ${ }^{11}$ |lu-mār-šarri-ēpušs ${ }^{12}$ nebo Mar-šarri-ilā'ī. ${ }^{13}$

\subsection{Korunní princ v požehnáních a modlitbách}

Asyrský následník je také velmi často zmiňován v dopisech adresovaných jeho otci, asyrskému králi. Jedná se především o požehnání, jež bylo součástí pozdravných formulí běžných v dopisech zasilaných vladaři jeho služebníky, ale přání štěstí, zdraví, dlou hých let a přizně bohů stejně jako zmínky o modlitbách za následníka trůnu se objevuji i ve vlastních textech dopisů. Požehnání bylo často směřováno ke korunnímu princi spolu s dalšími členy královské rodiny, nejčastěji králem, královnou nebo královnou matkou (viz například SAA X, text 16, ř. tev. 2 - 8, s. 14) a ostatním princủm (viz napřiklad SAA $X$, text 348, r. 17-21, s. 283), nebo pouze ke králi a korunnímu princi (viz např́klad SAA $X$, text 316, r. rev. 10-14, s. 256). V jednom z dopisů z období vlády panovníka Asarhad-

6) Akkadsky mār šarri rabû (log. DUMU-LUGAL GAL-e (viz naprǐklad SAA I, text 133, s. 110). 7) Akkadsky mār šarri ša bït ridûti (viz napríklad SAA IV, text 143, s. 154 (DUMU-LUGAL ša2 E2-UŠ-te), SAA IV, text 150, s. 161 - 162 (DUMU-LUGAL ša2 E2-re-du-ti), SAAIV text 156, s. 167-169 (DUMU-LUGAL ša2 E2-re-du-U2-te, DUMU-LUGAL ša2 E2-re-duu2-ti) nebo SAA IV, text 186, s. (DUMU-LUGAL ša2 E2-re-du-ti)).

8) Akkadsky mār šarri rabû ša bït ridûti (AfO Beih. 9, texty Trb. a A., Trb. B., s. 71- 72).

9) "Nabû, ochraňuj korunniho prince!" (PNA 2/II, s. 845).

10) Korunní princi, ochraňuj dédice!" (PNA 2/1, s. 532).

11) "Korunní princ je pán bratrü" (PNA 2/I, s. 532).

12) „Bůh stvoril korunniho prince” (PNA 2/I K, s. 532).

13) „Korunní princ je můjbůh” (PNA 2/II, s. 741). dona odesilatel piše, že bohové budou střežit [Aššurbanipala], velkého korunniho prince z Paláce následnictví, a [korunního prince] Babylónu" (SAA XIII, text 79, ř. rev. 1, s. 71) tedy Šamaš-šuma-ukīna. Dochoval se dokonce dopis, jehož jediným obsahem je požehnání korunnímu princi, ${ }^{14}$ kterému je také celý text adresován.

\section{Péče o královské děti}

Nejen korunnímu princi, ale všem královským potomkưm, ${ }_{15}^{15}$ se již od narození dostávalo náležité péče ve všech směrech. $V$ této oblasti jsou mám nepostradatelným zdrojem opět dopisy z období vlády krále Asarhaddona, který se úzkostlivě staral o vývoj svých dětí, a proto se o jejich stavu nechával podrobně informovat. ${ }^{16} \mathrm{Na}$ základě těchto dopisů můžeme usuzovat, že královské děti, alespoň v Asarhaddonově době, vyrưstaly pod dozorem kněží a dalších učenců, kteři pečovali nejen o jejich zdraví a výchovu, ale také dbali na to, aby se nedopustily nějakého prestupku v kultické sféře a bohové jim zůstali nakloněni. Ústřední postavou těchto dopisů je pochopitelně především následník trůnu, ${ }^{17}$ ale objevují se i zprávy o dalších královských dětech. ${ }^{18}$

14) „Korunnímu princi Asýrie, mému pánu, tvưj služebnik Adad-šumu-ușur, který tě neu stále velebí. [Dobréz zdra]ví korunnímu princi [z Paláce násled]nictví, mému pánu! [Nech Aššur, Si]]n, Šamaš, [Nabû, Marduk, a velcí bohové nebes i země požehnaji korunnímu princi, mému pánu. Necht' da]jí [rado]st [a zdra]ví [korunnímu pri]nci [z Paláce násled] nictví, mému pánu!" (SAA X, text 186, s. 153).

15) Akkadskyjsou královské děti nazývány mārē šarrigabbu (viz napríklad SAA I, text 133.a). 16) V dopise CT 5369 podává Adad-šumu-ușur králizprávu o těžkéchorobě jednoho z jeho malých děti: „Pokud jde o to, co mi napsal král, mưj pán: „Jsem velmi skleslý. Co jsme učinili (špatně), že jsem tak zesmutněl kvưli svému maličkému?" - kdyby byla (choroba) léćitelná, dal bys polovinu své země, aby se (maličké) vyléćilo! Ale co můžeme dèlat? Ó králi, můj pane, to je něco, co nemůže být uskutečněno." (SAA X, text 187, ř. 6-15, s. 154).

17) Přkikladem může být dopis adresovaný králi Asarhaddonovi, jehož autorem je UrduNanaia, vrchní královský lékař (viz PNA 1/II, s. 198). Dopis po pozdravné formuli, v niž je vedle svého chotě Ninurty zmíněna bohyně lékařství Gula, jejiž přizvisko znělo „velká hlavni lékařka bohü" (viz napřiklad RIMA III, text A.0.104.2010, ř. 7-8, s. 232), pokračuje následovně: „Korunnímu princi se daří velmi dobře. Vešel jsem do prítomností korunn ho prince a korunní princ mi řekl: "Celému mému tělu je lépe." Král, mưj pán, mưže být [štasten]." (SAA X, text 323, r. 7-12, s. 260-261).

18) Výše zmíněný Asarhaddonův vrchní lékař Urdu-Nanaia v jiném dopise informuje krále o zdravi prince Aššrr-etel-šamê-erșeti-muballissu, Aššurbanipalova bratra (SAA $X_{t}$ text 321, s. 259). 
Největší zájem měl ovšem Asarhaddon o zdravotní stav korunního prince Aššurbanipala, proto když korunní princ onemocněl, nechával si od jeho ošetřovatele posílat detailní zprávy o léčebných postupech ${ }^{19}$ a prostřednictvím věštců se tázal božstev, zda má princ podstoupit určitou léčbu ${ }^{20}$ a zda se uzdraví. ${ }^{21}$ Sám také podle následujícího úryvku z dopisu muže jménem Adad-šumu-ușur, vrchní zaklínač, jenž byl pověřen péči o prince Aššurbanipala (viz PNA 1/l, s. 39), navrhl, aby léky podávané princi nejdřive ochutnávali otroci: „Pokud jde o lék, o němž mi král, mưj pán, psal, mưj pán má naprostou pravdu. Necháme tyto otroky pít první, a korunní princ se napije až poté. Co jsem já, abych mluvil, starý muž, jenž nemá rozum. (Naopak) to, co řekl král, mưj pán, je dokonalé jako slovo boha." (SAA X, text 191, r. 5 - rev. 7, s. 156). I po svém uzdravení se

19) „Králi, mému pánu, tvưj služebník Urdu-Nanaia. Mnoho zdraví králi, mému pánu! Nech Ninurta [a] Gula dají radost a tělesné [zdra]ví králi, mému pánu! Korunnímu princi se dar̆ velmi dobře. Léčba, kterou jsme provedli a přiložili na hrud', trvala 1 a 1/2 hodiny. Züstal pr̆ vědomía poté se posadil (na svém lũžku). Je v porádku!" (SAAX, text 322, ř. 1-14, s. 260). 20) Podobné dotazy vznášené asyrským panovnikem k božstvưm byly velmi časté. Jejich predmětem byla rozličná rozhodnutí souvisejicí s chodem státu, válečnými výpravam is členy královské rodiny, ale prủběh rituálu byl vždy téměr stejný. Př̀islušný dotaz sdělli panovník věštci bārû, knězi vzdèlanému ve věštěni z vnitřností obětovaných zviřat. Ten poté dotaz zapsal na tabulku a předložilji božstvưm Šamašovi a Adadovi, božským patronưm věštby, prípadně pouze bohu spravedlnosti Šamašovi. Poté následoval časový úsek, během něhož měl Šamaš zaznamenat odpověd' do útrob zviřrete, jež bylo vybráno k nadcházejicí oběti. Když bylo zviře rituálně poraženo, prozkoumal kněz bārû jeho vnitřnosti a na základě zjištěných nálezů stanovil odpověd'bohů (podrobněji viz SAA IV, s. XVI-LV). $\checkmark$ následujíím textu je tázán bůh Šamaš, zda má korunní princ Aššurbanipal užít určité léky, a zda se poté uzdravi: „[Má Ǎšsurbanipal, korunní princ] Paláce následnictví, [vypit tento lék, který] je umístěn [préd] tvým velkým [bož]stvím, [a bude vypitím tohoto léku] zachráněn a ušetřen? [Bude žit a uzdraví se? Bude ..., za]chráněn a unikne? [Bude nemoc] jeho [těla] zažehnána? Opustí (jej]? Ví to tvé velké božství? [Je zách]rana (a) přežití [Aššurbanipala, korunniho prince Paláce následn]ictví, vypitím tohoto léku [rozhodnuta a potvrzena v prǐznivé situaci přikazem tvého velkého božstvi]', Šamaši, vznešený pane? [Spatři to ten, kdo je schopen to vidět]? Uslyší to [ten, kdo je schopen sly̌set]?" (...) „IPtám se tě, šamaši, vznešený paně, zda tento lék], který [je] nyni [umistěn před tvým velkým božstvím a který (se chystá) Aššurbanip]al, korunní princ Paláce následnictví vypít - [(zda) vypitím tohoto léku bude ......] zachráněn, [a unikne]. Bud' prítomen [v tomto beranovi, vlož (do něho) jasnou kladnou odpověd'...]" (SAA IV, text 187, ř. 1 - 9 a rev. 8-12, s. 190-191) 21) Napríklad $v$ textu BM 99062 je bůh Šamaš tázán, zda se Aššurbanipal uzdravíz bolestínadbrǐšku (SAA IV, text 188, s. 191-192). však korunni princ musel šetřit, a podle rad ošetřovatele nesměl po jedné z prodělaných chorob nějaký čas jezdit na koni a napínat luk (viz SAA X, text 192, s. 157).

\section{Volba korunního prince}

Nyní se však dostáváme k zásadní otázce, totiž na jakém principu probíhala volba následníka trůnu. Zdá se, že žádná závazná pravidla pro určení korunního prince neexistovala. Zpravidla sice býval za následníka trůnu považován nejstarší královský syn, avšak konečné slovo $v$ otázce nástupnictví měl panovník, který navíc mohl své rozhodnuti změnit. Legitimním důvodem ke změně nástupnictví samožrejmě bylo, když následník trůnu předčasně zemřel. Například Asarhaddon zvolil Aššurbanipala korunním princem až poté, co jeho starší bratr, Sīn-nādin-apli, předčasně zemřel (PNA 3/l, s. 1138). ${ }^{22}$ Krá Sinacherib změnil rozhodnutí ohledně volby svého nástupce dokonce dvakrát, aniž by došlo k úmrtí korunního prince. Poprvé roku 698 př. n. I., když o dva roky dříve svého nejstaršího syna a následníka trůnu Aššur-nādin-šumiho ustanovil králem Babylónie, ${ }^{23}$ do role korunního prince povýšil dalšího ze svých synů, Arda-Mullissiho (SAAS VII, s. 17). Později však své rozhodnutí z nám neznámých důvodů opět změnil a za svého nástupce určil jednoho ze svých mladšich synů, Asarhaddona. Sám Asarhaddon své zvolení popisuje následovně:

„I když jsem byl já mladší než moji velcí bratři, na rozkaz Aššura, Šamaše, Béla a Nabûa, Ištar z Ninive a Ištar z Arbely, otec, můj zploditel, mne pozvedl ze (všech) mých bratří a řekl: "Toto je můj následnik". Šamaše a Adada se obětí tázal a jasné ano mu odpověděli: „toto je tvưj nástupce”. Jejich závažné sdělení (otec) vyplnil a shromáždil obyvatele

22) Ohledně volby královského syna Sinn-nādin-apli se dochoval dotaz, který Asarhaddon predložil bohu Šamašovi: „Šamaši, vznešený pane, dej mi jasnou kladnou odpověd’na to, nač se tě táži! Má se Asarhaddon, král Asýrie, snažit a plánovat? Má nechat vejít svého syna, Sin-nādin-apliho, jehož jméno je zapsáno na tomto papyru před tvým velkým božstvím, do Paláce následnictví? Je to príjemné tvé božskosti? Je to vitané pro tvoji božskost? Ví o tom tvé božství? Je vstup Sinn-nādin-apliho, syna Asarhaddona, Krále Asýrie, jehož jméno je zapsáno na tomto papyru, do Paláce následnictví, stanoveno a potvrzeno v prírznivé situaci přikazem tvého velkého božství, Šamaši, vznešený pane? Spatří to ten, kdo je schopen to vidět? Uslyšíto [ten, kdo je schopen slyšet]?" (SAAIV, text 149, r.. 1-10, s. 160). Pozdějš́t texty však o princi Sinn-nādin-aplim mlčí, z čehož lze usuzovat, že žrejmě předčasně zemřel (STRECK, Maximilian, 1916, s. CLXXXV; PNA 3/I, s. 1138).

23) Sinacherib se o tomto svém rozhodnutíz roku 700 př. n. l. krátce zmiňuje v jednom ze svých nápisü: „Na svém čtvrtém tažen”i (...) „jsem na jeho(Marduk-apla-iddinưv) královskỳ trůn usadil Aššur-nādin-šumiho, svého nejstaršiho syna, zrozence z mých beder. Svěril jsem mu rozlehlou zemi Sumeru a Akkadu" (OIP II, text H2, sloupec III, r.. 50 a 72 - 74, s. 34-35) 
Asýrie, malé $i$ velké, mé bratry, před Aššurem, Sinem, Šamašem, Nabûem a Mardukem, velkými bohy Asýrie, bohy obývajícími nebesa a zemi, že budou chránit mé nástupnictvi. $\checkmark$ príhodném měsíci, ve dni stanoveném podle jejich vznešeného príkazu do bīt ridûti (domu následnictví), do mista bázně (vzbuzujicího úctu), v němž je základ království, jsem radost ně vstoupil. Tento čin (tvrdě) zasáhl mé bratry, kteří opustili (vưli) bohư, vzdorovali jejich pruánía osnovali zlé (činy). Lži, pomluvy a bezbožné výmysly si na mne vymysleli a proti mně vedli, falešnými obviněními za mými zády nenávist proti mně podněcovali. Chtěli popudit dobrotivé srdce mého otce, mně nakloněné, proti vüli bohů. Jeho srdce (však) bylo naplněno milostí a jeho zámérem bylo, abych vládu vykonával já." (NOVÁKOVÁ, Nea; PECHA, Lukáš; RAHMAN, Furat, 1998, s. 149-150).

Z Asarhaddonových slov je zřejmé, že zvolení mladšího z královských synu nebylo zcela běžné, přestože se jednalo o vưli krále. Ani on sám však nakonec za svého nástupce nezvolil svého nejstaršího potomka, ale jeho mladšího bratra Aššurbanipala. Dochoval se dokonce dopis, v němž již zmíněný Adad-šumu-ușur, jenž byl v Aššurbanipalových službách, gratuluje králi ke skvělému výběru. ${ }^{24}$

\section{Smlouvy o věrnosti korunnímu princi}

Aby král zajistil svému nástupci věrnost asyrských dvořanů i vazalů, nechal jak Sinache$\mathrm{rib}_{1}{ }^{25}$ tak také Asarhaddon ${ }^{26}$ sepsat smlouvu o věrnosti, v niž jednak jmenovitě následní-

24) Adad-šumu-ușur po pozdravné formuli piše: „Co nebylo vykonáno v nebesích, král, můj pán, učinil na zemi a ukázal nám. Oděl jsi svého syna čelenkov a pověril jej kralováním nad Asýrií, svého nejstaršiho syna jsi ustanovil k vládě nad Babylónem. Prvního jsi umistil po své pravici, druhého po své levici! (Když toto) jsme viděli, žehnali jsme králi, našemu pánu, a naše srdce byla nadšena. Necht' Aššur, Šamaš, Nabû, Marduk a velci bohové nebes a země nechaji krále, mého pána, spatritit, jak prospivaji!' Necht' Aššur, Adad a Šamaš, deset(krát) každý, urči osud králi, mému pánu, a jeho synům! Necht' Aššur učini tvé jméno věčným v nebesich i na zemi! Tak, jak jsi prípravil skvělou životní dráhu pro tyto své dva syny, priprav také skvělý osud pro (zbytek) svých početných synů! Vezmi je do (svého ochranného) stínu a bezpeči! At' jako sémě trávy vládnou nade všemi zeměmi! Necht' jsi dobrý k Asýrii - necht'je Asýrie dobrá k tobě!" (SAAX, text 185, r. 1-rev. 4, s. 152).

25) „[... kterou Sinach]erib, král Asýr[ie, tvưj pán], ti uložil. Jestliže bys slyšel nepatřične věci, promluvišs (a) [pưjdeš] k Sinacheribovi, králi Asýrie, [svému pánu], a zcela se oddás králi, svému pánu. Budeš chránit[Asarhaddona, zvoleného korunního prince, a] ostatn prince, [které ti Sinacherib, král Asýrie, ukáz]al." (SAA II, text 3, r. 1'-6'.

26) Asarhaddonova nástupnická smlouva ve prospěch Aššurbanipala byla sepsána 18. ajaru v eponymátu Nabû - bēlu-ușura, guvernéra Dūr-Šarukku (SAA II, text 6, ř. 664- 665, s. 58), tedy roku 672 př. n. l. (SAAS II, s. 61), ale samotná prísaha byla podle Aššurbani- ka uvedl, a také zavázal k poslušnosti a jeho ochraně všechny své poddané. Zajímavým dokumentem je rovněž smlouva, jíž uzavřela Sinacheribova manželka Naqīa (Zakūtu) s Šamaš-šuma-ukīnem, ostatními Asarhaddonovými syny, s asyrskými hodnostáři i veškerým lidem Asýrie, aby byli věrní korunnímu princi Aššurbanipalovi, chránili jej a neplánovali proti němu vzpoury. ${ }^{27}$ Tento text je dokladem toho, že

palových análů složena již o několik dní dríve, 12. ajaru: „Asarhaddon, král Asýrie, otec, mưjzploditel, měl vúctě slovo Aššura a Bēlet-ilī, svých pomocnikủ, jímž mi výkon královské vlády sveřili. V ajaru, měsici Ey, pána lidstva, dvanáctého dne, v prríznivém dni, ve svátek ŠUM-GAR(?) bohyně Guly(?), aby splnil vznešený přkkaz, který mu Aššur, Mullissu, Sinn, Šamaš, Adad, Bēl, Nabû, Ištar z Ninive, Královna z Kidmuri, Ištar z Arbely, Ninurta, Nergal a Nusku uložili, shromáždil lid Asýrie, velké i malé, od Horniho i Dolního moře. Aby mne v mé hodnosti korunního prince a budouciho vládce Asýrie chránili, nechal je smlouvu při [velkých] bozích odpř́sáhnout." (STRECK, Maximilian, 1916, Der Rassam Cylinder, sloupec 1, r. $8-22$, s. 2-5).

27) Smlouva Zakūtu, královny Sina[cheriba, kr]ále Asýrie, matky Asarhaddona, krále Asýrie, s Šamaš-šuma-ukinnem, jeho rovným bratrem, s Šamaš-mētu-uballi]em a se zbytkem jeho bratrů, s královským potomstvem, s hodnostárí a guvernéry, vousatými i eunuchy, královými nejbližšimi, stálým vojskem a všemi, kdo vstupují do paláce, s Asyřany, nízkými i mocnými. Kdokoliv, kdoje (zahrnut) v této smlouvě, kterou královna Zakūtus celou zemí uzavřela ohledně svého milovaného vnuka [Aššurba]nipala, kdokoliv (z vás), kdo by [...] osnoval a konal špatnou a zlou věc nebo se vzbouríl proti svému pánu Aššurbanipalovi, králi Asýrie, ve svých srdcich zplodil a vtělil do slov špatnou [int]riku nebo zlé spiknuti proti [svému pánu] Aššurbanipalovi, králi Asýrie, [ve sv]ých [srdcích] zamýšlel a plánoval špatnou radu a zlé doporučeni ke vzpouře a povstáni proti svému pánu Aššurbanipalovi, králi Asýrie, (nebo) se spikl [s] někým jiným [... ] k vraždě svého pána [Aššurbanipala, krále] Asýrie: [Necht' Aššur, Sinn, Šamaš], Jupiter, Venuše, Saturn, Merkur, [Mars, and Sírius] [...] [ji]hu i [severu]. [A jestliže] od tohoto dne (uslyšite) špatné [slovo] o vzpouře a povstán vyslo[vené proti] svému pánu Aššurbanipalovi, králi Asýrie, príjdete a podáte zprávu Zakūtu, jeho matce, a Aššurbanipalovi, [králi Asýrie], svému pánu. A jestliže zaslechnete (plán) o zabití či odstraněni svého pána [Aššur]banipala, krále Asýrie, príiddete a podáte zprávu Zakūtu, [jeho matce], a svému pánu Aššurbanipalovi, králi Asýrie. A jestliže uslyšite o špatné [intrice] zosnované proti vašemu pánu Aššurbanipalovi, králi Asýrie, musíte promluvit v prítomnosti Zakūtu, jeho matky, a svého pána Aššurbanipala, krále Asýrie. A jestliže uslyšíte a budete vědět, že jsou ve vašem středu lidé, kteřínaváději k ozbrojenému povstánínebo podněcuji spiknutí, at’ už vousatí či eunuši nebo jeho bratři nebo (někdo) $\checkmark$ jeho blizkosti nebo vaši bratř̌ či prátelé nebo kdokoliv v celé zemi - měli byste slyše a [vědět] (to, že) je musite chytit a [zabít] a privivést k Zakütu, [jeho matce, a k Aššurbani] palovi, [králi Asýrie, vašemu pánu]." (SAA II, text 8, s. 62-64). 
ani po Sinacheribově smrti neztratila tato energická žena svưj vliv a aktivně zasahovala do volby následníka trůnu.

\section{Bīt ridûti a jeho personá}

Po svém oficiálním jmenování se následník přestěhoval do takzvaného Paláce následnictví (bït ridûti; viz CAD R, s. 326 - 327), který se stal sídlem celé rodiny korunního prince, ${ }^{28}$ a také administrativním centrem říše, nebot korunní princ byl plně zapojen do správy státu. Král Aššurbanipal v jednom ze svých nápisư popisuje vstup do bīt ridûti následovně:

"S radostí(a) nadšením vešel jsem do bīt ridûti, mista vědění, pouta kralováni, $v$ němž Sinacherib, mưj děd, jako královský syn (dlel) a královský úrad vykonával, (a) $\checkmark$ němž se Asarhaddon, otec, můj zploditel, zrodil, vyrůstal, vládu nad Asýrií vykonával, všem vládcům panoval(?), rodinu rozširíil(?) a členy domácnosti a př́buzné shromáždil. Také já, Aššurbanipal, jsem si tam moudrost Nabûovu, celé pisařské umění (a) všechny dovednosti, kolikjich bylo, osvojil." (STRECK, Maximilian, 1916, s. 5).

Být ve službách korunního prince patřilo $k$ nejprestižnějším zaměstnáním ve státě. Kupřikladu Aššurbanipalův vychovatel (viz SAA IV, s. XXXI.), astrolog Balasî (viz PNA 1/II), piše králi: „vskutku, komu věnoval král takovou prízeň jako mně, když jsi mně určil pro službu korunnímu princi, abych byl jeho učitelem a vzdělával jej?" (SAA X, text 39, ř. rev. $4-9$, s. 30). Vedle Balasîho bylo ve službách korunního prince velké množství běžného služebnictva ${ }_{1}{ }^{29}$ ale také princovi nejbližší rádcové a služebníci ${ }^{30}$

28) V následujicím dopise adresovaném Libbāli-šarrat, ženě korunniho prince Aššurbanipala, se pisatelka Šerua-etirat, Aššurbanipalova sestra, nazývá "nejstaršídcerou Paláce následnictvi". Text je rovněž dokladem toho, že ani vztahy uvnitř ženské části královské rodiny nebyly vždy dobré: "Slovo královy dcery k Libbāli-šarrat. Proč nenapišeš tabulku, svưj cvičný text neuděláśs? Pokud to neučinišs, řeknou si: „Toto je sestra Šeruy-ețirat, nejstarší dcery Paláce následnictví Aššur-etel-ilāni-mukīnniho, velkého krále, mocného krále, krále světa, krále Asýrie?" Nicméně ty jsi (pouze) snacha, žena $z$ domácnosti Aššurbanipala, velkého korunniho prince zvoleného Asarhaddonem, králem Asýrie" (SAA XVI, text 28, s. 23). Aššur-etel-ilāni-mukīnni je pravděpodobně zkratkou jména Aššur-etel-ilāni-mukīn-apli, druhého jména panovníka Asarhaddona (PNA 1/l, s. 184).

29) Tito lidéjsou v textech nazýváni jednoduše „služebnik korunniho prince”, akkadsky ardu ša mär šarri (napr. LU2ARAD ša DUMU-MAN; viz SAA VI, text 52, r. rev. 17, s. 52). 30) Napřkiklad pobočník korunniho prince (akkadsky mār qāti ša mār šarri; např. LU2DUMU-ŠU.II ša DUMU-MAN; SAA XIV, text 125, ř. rev. 5'- 6', s. 104) nebo vrchní eunuch korunniho prince (akkadsky rab ša rēši ša mār šarri; např. LU2GAL-SAG ša2 A-MAN, další lidé specializovaní na různé činnosti spojené s chodem princovy domácnosti, ${ }^{31}$ administrativou a správou následníkova majetku, ${ }^{32}$ vojenskou službou ${ }^{33}$ a ochranou korunního prince, ${ }^{34}$ jakož i osoby dozírající na kultovní a rituální čistotu následníka a celé jeho domácnosti. ${ }^{35}$ Mimo tyto osoby podřizené prímo korunnímu princi se v Paláci ná-

SAAXIV, text 40, r. 2, s. 44) spolu s ostatními eunuchy korunniho prince (akkadsky ša rēši ša mār šarri; napr. LU2SAG ša DUMU-LUGAL; SAA VI, text 287, ř. 13, s. 231).

31) $V$ textech jsou doloženi: správce domácnosti korunniho prince (akkadsky ša muhhi bit mār šarri; např. LU2ša2-UGU-E2 A-LUGAL; SAA XII, text 92, ř. rev. 7, s. 116), vrátny korunniho prince (akkadsky atû mār šarri; např. LU2I3.DU8 A-MAN; SAA VI, text 299, r. rev. 8, s. 242) nebo vrchní kuchař korunniho prince (akkadsky rab nuhatimmi ša mār šarri; napr. LU2GAL-MU ša2 A-MAN; SAA XIV, text 307, r. rev. 5', s. 216).

32) Objevují se: správce vesnic korunniho prince (akkadsky rab àlāni ša mār šarri; např LU2GAL-URU.MEŠ ša2 DUMU-MAN; SAA VI, text 109, ř. 6- 7, s. 100), guvernér korunniho prince (akkadsky pāhutu ša mār šarri; např. LU2EN. NAM ša DUMU-MAN; SAA XIV text 23, ř. 4, s. 28), mistodržící korunního prince (akkadsky šakin mār šarri; např. LU 2GAR-nU DUMU-MAN; SAAXIV, text 318, r. rev. 5', s. 220), treasurer of the crown prince (akkadsky masennu ša mār šarri; např. LU2IGI.DUB ša DUMU-MAN; SAA VI, text 287, ř. rev. 11, s. 231), obchodník korunniho prince (akkadsky tamkāru ša mār šarri; např̆. LU 2DAM.KAR3 ša DUMU-MAN; SAA VI, text 210, r. 14, s. 170), pisař korunniho prince (akkadsky țupšarru ša mār šarri; napr̆. LU2A. BA ša2 DUMU-MAN; SAA VI, text 57, r. rev. 1 s. 55) nebo aramejský pisař (akkadsky tupšar armāia ša mār šarri; např. LU2A.BA KUR:ar2-ma-a-a ša A-MAN; SAA XIV, text 205, r. rev. 13, s. 165).

33) Kupríkladu vozataj korunního prince (akkadsky mukīl appāti ša mār šarri; např. LU 2DIB.KUŠ. PA.MEŠ ša A-MANi SAA IV, text 283, r. rev. 16, s. 228), "třetí muž" (ve voze) korunniho prince (akkadsky tašlišu ša mār šarri; např. LU23.U5 ša A-MAN; SAA VI, tex 199, r. rev. 6', s. 158), trenér koní či spiše vozataj korunního prince (akkadsky sūsān mār šarri; např. LU2. GIŠGIGIR A-MAN; SAA XIV, text 287, ř. rev. 6', s. 208), chovatel (koní) korunniho prince (akkadsky muribbānu ša mār šarri; např. LU2muribbānu ša DUMU MAN. SAA VI, text 37, r. rev. 7, s. 40), velitel oddilu korunniho prince (akkadsky rab kişi ša mār šarri; např. LU2GAL-ki-șir ša2 DUMU-MAN; SAA VI, text 299, ř. rev. 5, s. 242) či dưstojnik zpravodajské služby korunniho prince (akkadsky mutīr țēmi ša mār šarri; napr̆. LU2mu-tar-UMUŠ ša A-MAN; SAA XIV, text 169, ř. rev. 7, s. 140).

34) Velitel strážce korunniho prince (akkadsky rab kișir qurbüti ša mār šarri; LU2GAL-kisir qur-ZAG ša A-MAN; SAA XIV, text 29, r. 6-7, s. 31), strážce korunního prince (akkadsky ša qurbūti ša mār šarri; např. LU2qur-ZAG ša A-MAN; SAA IV, text 325, ř. rev. 19', s. 264) nebo osobni strážce korunniho prince (akkadsky ša šêpi ša mār šarri; např. ša GIR3.II ša A-MAN; SAA IV, text 325, ř. rev. 20', s. 264).

35) Vrchní zař́kávač domu korunniho prince (akkadsky rab āšipi ša bīt mār šarri 
slednictví objevují také lidé ve službách následníkovy ženy ${ }^{36}$ a personál sloužící nejvyšším hodnostářưm korunního prince..$^{37}$ Jejich jména se dochovala predevším ve smlou vách, kde tito lidé figuruji převážně jako svědkové.

\section{Role korunního prince ve správě státu}

Pokud jde o roli korunního prince ve správě státu, byl následník pravou rukou svého otce a zřejmě jej dokonce zastupoval, když byl král na válečných taženích mimo Asýrii (viz SAA V s. XVI). I v době královy př́tomnosti mu však byly svěřeny některé významné funkce. Jak vyplývá z dotazů kladených slunečnímu bohu Šamašovi, mohl korunni princ napríklad jmenovat některé administrativní i chrámové úředníky. ${ }^{38} \mathrm{Královská} \mathrm{ko-}$ respondence zase ukazuje, že přinejmenším princové Sinacherib ${ }^{39}$ a Aššurbanipal měli také na starosti informace podávané zvědy z pohraničních oblastí (viz SAA IV, s. LVIIIn). Určité pravomoci měl následník i v oblasti soudnictví, nebot'se na něho v dopisech obraceli lidé, jimž se stalo nějaké bezprávíi ${ }^{40}$ a v jednom soudním rozhodnutí týkajícím se

např. LU2GAL:MAŠ.MAŠ ša2 E2 A-MAN; SAA XIV, text 264, ř. 3', s. 197), zaříkávač ve službách korunniho prince (akkadsky āšipu ša ina pāni mār šarri; např. LU2MAŠ. MAŠ ša ina IGI DUMU-MAN: SAA X, text 257, r. rev. 4-5, s. 203) nebo osoba starající se o ochranné božstvo šêdu v paláci korunniho prince (akkadsky amēl šêdi ša bït mār šarri; např. LU2..DALAD ša E2 DUMU-LUGAL; SAA VI, text 288, ř. 18, s. 232). 36) V jednom textu se napríklad objevuje bojovník ve voze ve službách paní domu korunniho prince, tedy jeho choti, akkadsky nazývaný mār damqi ša bēlet bīti ša mār šarri (např. A-SIG ša2 GAŠAN-E2 ša2 DUMU-MAN; SAA VI, text 200, r. rev. 7 „ s. 159).

37) Napríklad trenér koní/ vozataj vrchniho eunucha korunního prince (akkadsky sūsān ša rab ša rēši ša mār šarri; napr̆. LU2GIGIR LU2GAL-SAG ša2 A-MAN; SAA XIV, text $40, r .2$, s. 44)

38) $V$ jednom $z$ textů z obdoví vlády krále Asarhaddona je např̌klad vznesen dotaz k bohu Šamašovi, zda má princ Aššurbanipal dosadit jistého muže do funkce vysokého kněze v Mardukově chrámu (viz SAA IV, text 266, s. 240 - 241).

39) Královská korespondence z obdobi vlády panovníka Sargona II. obsahuje několik textů, v nichž korunní princ Sinacherib posilá svému otci zprávy, které obdržel od zvědů pů sobicich na hranici se státem Urartu (např. SAA I, texty 29-32, s. 28-33).

40) Napríklad v textu ABL 152 se jistý Dadî dovolává spravedlnosti korunního prince ná sledovně: , Korunnímu princi, mému pánu, tvưj služebník Dadî, syn Bēl-rēmanniho, kněze v Bït Kidmuri. Necht'Aššur a Ištar žehnají korunnímu princi, mému pánu. Vrchnídodavatel potravin mne uvěznil a vyslýchal mne bez (povolení) krále nebo korunního prince. Uloupil mé dědictví. Vše, co můj otec nabyl pod královou ochranou, uloupil a odnesl. Zàroveň odnesl jeden talent čistého střibra a dvacet min stříbra v domácím náčiní - dary

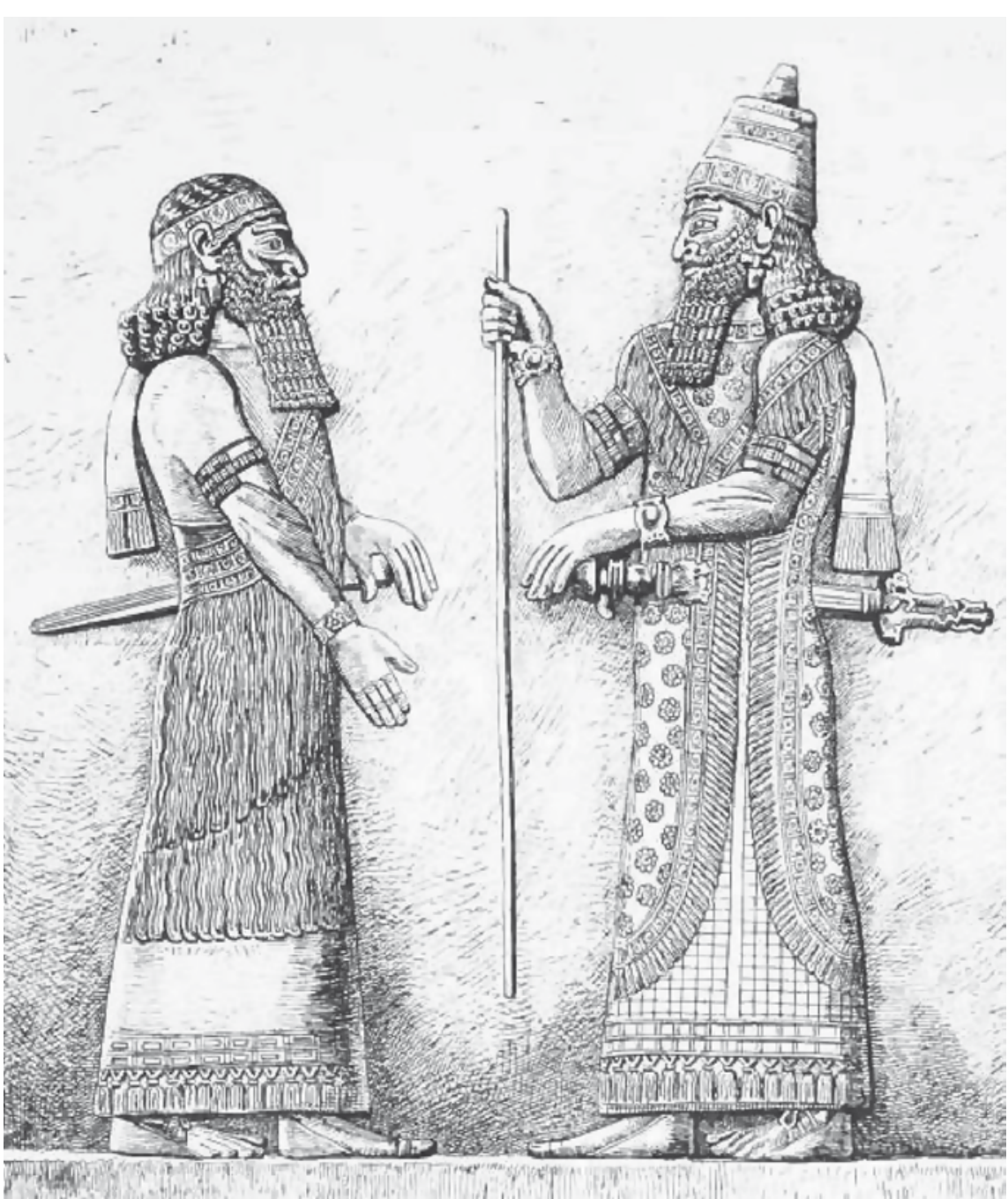

Král Sargon II. a korunní princ Sinacherib (PERROT, Georges a CHIPIEZ, Charles, 1884, s. 96 ) 
majetku jistého hodnostáře se dokonce praví: „kdokoliv poruší tuto smlouvu, král a korunní princ budou jeho žalobci" (SAA VI, text 238, ř. 9 -10, s. 187), a budou tedy vymáhat spravedlnost.

\section{Role korunního prince v kultu}

Povinnosti asyrského korunního prince se ovšem nevztahovaly pouze na světské záležitosti, ale následník byl vázán rovněž na sféru kultickou. Veškeré dění ohledně osoby korunního prince se, stejně jako v prípadě asyrského krále, ř́dilo rituálními předpisy a vưlí bohů zjevovanou prostřednictvím věštebných znamení. Ve jménu následníka i ostatních královských potomků byly přinášeny oběti božstvưm. ${ }^{41}$ Pokud se objevila neblahá znamení, konaly se pro korunního prince rituály k odvrácení zlých sil. ${ }^{42}$ Rovněž návštěvy chrámư ${ }^{43}$ a dokonce

krále a královny matky. Já jsem zdědil úrad svého otce, (ale nyni) jsem byl (dokonce) vyhnán z paláce. Necht'se korunní princ (o toto) postará, abych nezemřel bez (pomoci) krále nebo korunniho prince." (SAA XIII, text 154, s. 126).

41) V dopise ABL 113 Urdu-Nabû podává králi zprávu o nadcházejicich obětech za jeho děti: „Vydal jsem pokyny týkajicí se obětíza Aššurbanipala, vel[kého korunn]ího prince, za Šamaš-šuma-ukīna, korunniho prince Babylónu, za Šeru'u-ețerat, za Aššur-mukīn-paleiu a za Aššr[ur-et]el-šamê-erșeti-muballissu. [Přrine]su jejich oběti před Nabûa a Tašmētu a vykonám je v [lož]nici. Necht'jim doprejil 100 let života. jejich děti a vnuciat’'se dožijívysokého stáří k král, můj pán, necht'je uvidi (vyrưstat)." (SAA XIII, text 56, ř. rev. 6-17, s. 52). 42) Př̆kladem může být text ABL 1099, v němž Marduk-šăkin-šumi, jeden z nejpředněj ších vzdělanců královského dvora, informuje panovníka o průběhu rituálů prováděných na základě pozorováni planety Mars: „Pokud [jde o pozorování] Marsu, [o němž mi král můj pán], psal: „Vykonej [jeho (rituály) modliteb „pozvednutí ruky”] a vykonej je téź p[ro korunniho prince]" - [Již] jsem s nimi [za]čal, (ale) [če]kám na [...]." (viz PNA 2/II, s. 722 723), (SAA X, text 262, r. 5-10, s. 205-207). Jak však dokazuje dopis ABL 23 pocházejicí od stejného autora, rituály za korunniho prince mohly být konány i preventivně, aniz by se objevilo nějaké zlé znameni: "Otevřel jsem své ruce a modlil se k bohům: vše je dobré, bohové požehnali králi, mému pánu, a jeho synưm. Nicméně, pokud si to král žádá, necht' napišído Kalhu a vykonaji (rituály) modliteb „pozvednutíruky" pred měsičnim božstvem a apotropaický rituál proti zlu všeho druhu pro korunního prince a prince Babylónu. Jak (by to mohlo) uškodit?" (SAA X, text 240, r. rev. 6- 20, s. 191).

43) Následujicí text se týká návštěvy posvátných míst korunním princem Aššurbanipalem: „[Aššurbanip]al, korunni princ [Paláce následnictví, který mno]ho [dní], měsíc za měsícem, dnem i nocí bě[doval před tvým vznešeným božstvím, ó Šamaši, vel]ký [pane, a (kterého) tvé vznešené božstvízná] - [v souladu s prík]azem tvého vznešeného božstvi Šamaši, velký pane, a [tvými př́znivými rozhodnu]tími, smí osoba (jmenovaná) v tomto inávštěvy královského otce, to vše se řídilo rozhodnutím věštcư o tom, zda je daná doba príznivá či neni. ${ }^{44}$

Z asyrského pantheonu měl následník trůnu úzký vztah obzvláště ke "korunnímu princi bohư", ${ }^{45} \mathrm{k}$ bohu Nabûovi, který určoval osud korunního prince a byl jeho patronem (viz SAAS XIV, s. 57 a 72). S bohem Nabûem, jenž byl čas od času zaměňován $s$ bohem Ninurtou, byla ztotožněna planeta Merkur, která byla zároveň planetou korunního prince ${ }^{46} a$ hrála ústřední roli $v$ astrologických věštbách, jež se $k$ jeho osobě vztahovaly. ${ }^{47} \mathrm{O}$ těsném spojení mezi korunním prince a bohem Nabûem svědči i úryvek

dotazu, Aššurbanipal, korunni princ Palá[ce následnictví - at'] (se) to (týká) jeho či jeho otce Asarhaddona - uchopit [ruku boha nebo] ruku bohyně nebo rukujejich (osobniho) božstva nebo ruku [jejich] (osobni) boh[hyněnebo] rukujejich městského boha nebo rukujejich městské bohyně [nebo ruku] boha jejich nejvýznamnějš̌ich svatostánků a navštivit [posvát ná mista] svých [bohů, věnovat] jim votivní dar(y) a predměty žádané [bohy a bohyněmi], aby [hněv boha] a bohyně [nepostihl] Aššurbanipala, korunniho [prince Paláce následnictvía Asar.haddona, krále Asýrie, jeho otce?" (SAA IV, text 196, r.. 1'-12', s. 197).

44) Nabû-ahhēe-erïba, významný astrolog a hemerolog u Asarhaddonova královského dvora v Ninive, podává v dopise ABL 82+ přesný rozpis rituálních úkonů, které má korun ni princ vykonat v prvnich dnech měsice nisannu, a také uvádí dobu vhodnou k návštěvě krále: „Co se týče korunniho prince, o němž mi král, můj pán, psal rǐkaje, že by korunn [princ mèl navštívit kr]ále, mého pána, (a ptaje se): „Je první den v nisannu príznivý?" Prvniho nisannu by [se] měl o[mýt a o]čistit, prinést obět' potravin pro Marduka, vykona úlitbu vody a prvotř́dního piva napravo a nalevo. Pak bude tento muž zárít jako slunce. Druhého dne by neměl vycházet do ulic. Čtvrtého nisannu by se mèl vrhnout na zem před Mardukem a uvést své znamení ve známost, (poté) mu bude doprána sláva a blahobyt. "Mel by uvést své znamení ve známost" (znamená), že by měl preednést svưj prípad před bohem. Jiná věc: Planeta Merkur září [vel]mi jasně - znači korunního prince. To je [přiznivé] pro Subartu [a př̆iz]nivé pro krále a korunniho prince. (Jestliže) se korunnípri[nc] chystá vejít do prítomnosti krále, [mého pána], je (nyni) [prírznivé] to učinit." (viz PNA 2/II, s. 794- 796), (SAA X, text 74, r. 6- rev. 11, s. 55-56).

45) Korunním princem bohů je Nabû nazýván napríklad $v$ Aššurbanipalově Hymnu k Tašmētu a Nabûovi: „Požehnej mi, korunní princi bohư!” (kur-ba-an-ni DUMU-MAN DIN GIR.MEŠ; SAA III, text 6, r. 3, s. 17).

46) Zatímco planetoujeho otce, krále Asýrie, byl Saturn (viz SAAX, text 51, ř rev. 8-9, s. 38). 47) Napřiklad vjednom z doporučení, kdy smíkorunníprinc navštívit svého otce, astrolog Balasî, Aššurbanipalův vychovatel, piše: „Planeta Merkur (značí) korunniho prince." (SAA X, text 52, r. rev. 9, s. 39). V podobném duchu se vyjadřuje rovněž další významný astrolog a hemerolog, Nabû-ușur-erïba, v dopise ABL 82+ (viz SAAX, text 74, r. rev. 5-6, s. 56; citace textu v pozn. 44). 
následující textu adresovaného jedním z učenců králi Aššurbanipalovi: „Kř́žž je emblémem boha Nabûa. Král, mưj pán, ví, (že) kvůli tomuto (spojení) je kříž symbolem korunního prince. Král, mưj pán, nyní jednal, jak náleží jeho důstojnosti: emblém byl vystaven [v] "Domě Ešnunny". Řikají něm: "Je to bưh Nabû (sám)." "(SAAX, text 30, ř. 3-7, s. 22-23). Zřejmě díky této vazbě měl princ Aššurbanipal také na starosti prípravy a organizaci $\mathrm{Na}$ bûových slavností, které se konaly v měsíci ajaru ve městě Kalhu.

\section{Závěr}

Z novoasyrských dokladů je zřejmé, že adept na úrad budoucího asyrského krále muse být osobou schopnou po všech stránkách, a že zastávat úrad asyrského korunního prince byl bezesporu velmi náročný úkol. V asyrské říši nebylo přesně stanovené nástupnické právo, a tak volba následníka trůnu závisela pouze na vơli panovníka, který do této funkce zvolil jednoho ze svých synů. Ještě za králova života byly princovy vlastnosti a schopnosti důkladně prověřovány, a tak se občas stalo, že král svoji vưli ohledně následnictví v průběhu své vlády změnil, v jednom př́padě dokonce dvakrát. Korunní princ byl zapojován do nejrůznějších činností souvisejících s chodem státu, aby plně pronik do povinností asyrského panovníka. Princ následník byl také, stejně jako jeho otec, pev ně spjat s kultickou sférou. Na jeho rituální čistotu a správné konání dbali nejpřednějši učenci asyrského královského dvora z řad kněží, kteří za korunního prince přinášeli oběti bohům, konali očistné rituály a na základě astrologických pozorování určovali, který den je př́znivý pro určitou činnost. Nicméně na základě dochovaných pramenů, z nichž naprostá většina pochází až z posledního století trvání asyrského státu, Ize jen stěži hodnotit instituci ưradu korunního prince v průběhu celých asyrských dějin. Jsme schopni pouze $v$ hrubých obrysech nastínit tuto funkci v období vlády Sargonovcủ, které je však v historii Asýrie dobou v mnoha ohledech výjimečnou. ${ }^{48}$

Literatura

ANNUS, Amar (2002): The God Ninurta in the Mythology and Royal Ideology of Ancient Mesopotamia [SAAS XIV]. Helsinki. Helsinki University Press.

BAKER, Heather D. (ed.) (2000): The Prosopography of the Neo-Assyrian Empire: $\mathrm{H}-\mathrm{K}$ [PNA 2/l]. Helsinki. Helsinki University Press.

BAKER, Heather D. (ed.) (2001): The Prosopography of the Neo-Assyrian Empire: L - N [PNA 2/II]. Helsinki. Helsinki University Press.

BAKER, Heather D. (ed.) (2002): The Prosopography of the Neo - Assyrian Empire: P - S [PNA 3/l]. Helsinki. Helsinki University Press.

BORGER, Riekele (1956): Die Inschriften Asarhaddons, Königs von Assyrien, [AfO Beih, g], Graz
COLE, Steven W. a MACHINIST, Peter (1998): Letters from Assyrian and Babylonian Priests to Kings Esarhaddon and Assurbanipal [SAA XIII] Helsinki. Helsinki University Press.

FALES, F. M. a POSTGATE, J. N. (1995): Imperial Administrative Records, Part II [SAA XI]. Helsinki. Helsinki University Press.

GRAYSON, A. Kirk (1996): Assyrian Rulers of the Early First Millennium B. C., Part II, [RIMA III]. Toronto. University of Toronto Press.

KWASMAN, Theodore a PARPOLA, Simo (1991): Legal Transactions of the Royal Court of Nineveh, Part [SAA VI]. Helsinki. Helsinki University Press,

ANFRANCHI, Giovanni B. a PARPOLA, Simo (1990): Letters from the Nortern and Northeastern Provinces [SAA V]. Helsinki. Helsinki University Press.

LIVINGSTONE, Alasdair (1989): Court Poetry and Literary Miscellanea [SAA III]. Helsinki. Helsinki University Press.

LUCKENBILL, Daniel David (1924): The Annals of Sennacherib [OIP II]. Chicago. The University of Chicago Press. LUKKO, Mikko a BUYLAERE, Greta Van (2002): The Political Correspondence of Esarhaddon [SAA XVI]. Helsinki. Hesir

MATTILA, Raija (2002): Legal Transactions of the Royal Court of Nineveh, Part II, [SAA XIV]. Helsinki. Helsink University Press.

MELVILLE, Sarah C. (1999): The Role of Naqia/Zakutu in Sargonid Politics [SAAS IX]. Helsinki. Helsinki University Press.

MILLARD, Alan (1994): The Eponyms of the Assyrian Empire $910-612$ BC [SAAS II]. Helsinki. Helsinki University Press. Kirjapano Oy.

NOVÁKOVA, Nea, PECHA, Lukáš a RAHMAN, Furat (1998): Dějiny Mezopotámie. Praha. Karolinum.

PARPOLA, Simo (1997): Assyrian Prophecies [SAA IX]. Helsinki. Helsinki University Press.

PARPOLA, Simo (1993): Letters from Assyrian and Babylonian Scholars [SAA X]. Helsinki. Helsinki University Press.

PARPOLA, Simo (1970): Letters from Assyrian Scholars to the Kings Esarhaddon and Assurbanipal [AOAT 5/1]. Neukirchen-Vluyn. Neukirchener Verlag.

ARPOLA, Simo (1983): Letters from Assyrian Sch 5/2]. Neukirchen-Vluyn. Neukirchener Verlag.

PARPOLA, Simo (1987): The Correspondance of Sargon II, Part I: Letters from Assyria and the West [SAA I]. Helsinki. Helsinki University Press.

PARPOLA, Simo a WATANABE, Kazuko (1988): Neo-Assyrian Treaties and Loyalty Oaths [SAA II]. Helsinki. Helsinki University Press.

ARPOLA, Simo a Porter, Michael (2001): The Helsinki Atlas of the Near East in the Neo-Assyrian Period. Helsinki. Helsinki University Press.

PERROT, Georges a CHIPIEZ, Charles (1884): A History of Art in Chaldea in Chaldea and Assyria. Lodon. Chapman and Hall.

PORTER, Barbara Nevling (2004), Ritual and Politics in Assyria: Neo-Assyrian Kanephoric Stelai for BabyIonia, in: Hesperia Supplements, Vol. 33, XAPIV: Essays in Honor of Sara A. Immerwahr, s. 259-274, American in: Hesperia Supplements, Vol. 33, XAP

RADNER, Karen (ed.) (1998): The Prosopography of the Neo-Assyrian Empire: A [PNA 1/l]. Helsinki. Helsinki University Press.

RADNER, Karen (ed.) (1999): The Prosopography of the Neo-Assyrian Empire: B - G [PNA 1/ll]. Helsinki. Helsinki University Press. 
REINER, Erica (ed.) (1999): The Assyrian Dictionary of the Oriental Institute of the University of Chicago, Vol. 14 [CAD R]. Chicago. The University of Chicago Press.

Barbora Polifková

STARR, Ivan (1990): Queries to the Sungod [SAA IV]. Helsinki. Helsinki University Press.

Barbora Polifková

STRECK, Maximilian (1916): Assurbanipal, Teil l.. Leipzig.

STRECK, Maximilian (1916): Assurbanipal, Teil II.. Leipzig.

WATERMAN, L. (1930): Royal Correspondence of the Assyrian Empire, Part I. University of Michigan Press.

\section{Použité zkratky}

ABL R. F. Harper, Assyrian and Babylonian Letters, Chicago $1892-1914$

AfO Beih. Archiv für Orientforsching, Beiheft, Berlin, Graz a Horn, 1933 .

AOAT Alter Orient und Altes Testament, Neukirchen-Vluyn, 1968-

BM Muzejní značka objektư uložených v Britském muzeu v Londýně

CAD Chicago Assyrian Dictionary of the Oriental Institute of the University of Chicago, Chicago, 1956 -

CT Cuneiform Texts from Babylonian Tablets in the British Museum, London, 1896-

OIP Oriental Institute Publications, Chicago

PNA The Prosopography of the Neo-Assyrian Empire, Helsinki

RIMA The Royal Inscriptions of Mesopotamia, Assyrian Periods, Toronto, 1987-

SAA State Archives of Assyria, Helsinki 1987-

SAAS State Archives of Assyria Studies, Helsinki 1992-

\section{Prvorozenectvív knize Genesis prizmatem sociálnía kulturní antropologie $^{1}$}

\section{Abstract}

Primogeniture, or succession by the eldest son, seems to have been the preferred rule in ancient Israel as this institution is explicitly promulgated in one passage (Dt 21:15-17), and is implicitly assumed in many accounts of individual cases. However, biblical acknowledgement of primogeniture usually occurs in contexts where the rule is broken as in the life histories of important religious and political figures, including Isaac, Jacob, Joseph, and David. The paper will discuss possible interpretations of these transgressions with the help of textual analysis confronted with archeological picture of the times, where the crucial texts redactions were done. Basically the main concern of the paper is not the historical or anthropological "correction" of biblical text but deeper understanding of the editorial intensions which undoubtedly transformed the ancient traditions about ancestors. 


\section{Úvod}

Primogenitura ${ }^{2}$ tedy následnictví nejstaršího, prvorozeného syna, se zdá být ve starověkém Izraeli preferovaným pravidlem. Explicitně je toto pravidlo vyjádřeno $v$ Deuteronomiu 21,15-17 a implicitně je $v$ textu předpokládáno $v$ mnoha individuálních případech. Nicméně biblické potvrzení primogenitury se často vyskytuje v kontextu, kdy je pravidlo porušeno, jako je tomu v životních príbězích významných náboženských a politických postav, jako např. Izáka, Jákoba, Josefa a Davida.

Tento přispěvek se zaměří na možné interpretace těchto transgresí s ohledem na antropologické přistupy konfrontované s archeologickým obrazem doby, ve které probíhaly zásadní redakce biblického textu (deuteronomistická a mladší). Jiným slovy se pokusím ukázat možnosti a limity sociálně antropologických přistupů. $V$ zásadě nepůjde o historickou nebo antropologickou "korekci” biblického textu, nýbrž o mož nost hlubšího porozumění redakčním záměrům, s nimž byly nepochybně prastaré tradice o predcích přetaveny.

Kritické studie Starého zákona prokázaly, že knihu Genesis tvoří minimálně 4 prameny - nejranější prameny (J E a D) maji svưj původ v 8. století př. n. I., nejmladši pramen $(P)$ pak pravděpodobně spadá do období Babylónského exilu, či spíše až do období po exilního, tedy 6 . stol. př. n. I. ${ }^{3}$ Mnohé z materiálu obsaženého v Gn spiše reflektuje idealizovanou verzi sociální struktury než etnografickou realitu ${ }^{4}$ a slouží tak jako vysvětlení a ospravedlnění politických a sociálních institucí existujicích v době redakce textu. Tímto neříkáme, že přiběhy předků jsou zcela ahistorické. Je jasné, že popisy starověkých pasteveckých skupin, sociálních a ekonomických podmínek a právních zvyků jsou poměrně autentické $v$ kontextu starověkého Blízkého východu a nalezneme je i v tradičních ves nických či zemědělsky založených společnostech (MATTHEWS, Victor H., 2002, s. 1).

2) Se sociálně-antropologickým konceptem ,primogenitury" v tomto př́spěvku pracuj tak, jak je uživán v antropologické teorii príbuzenství, tedy jako s jistým pravidlem (či chceme-li ideálem, normou, vzorcem jednáni v určité společnosti). Jak však správně poznamenal doktor Marek Jakoubek, a tímto mu děkuji za prípomínku, současná antropologie od tohoto prístupu ustupuje a v dané problematice hovoři spiše o "prìstupech" č "strategiích".

3) Více k Pentateuchu jako celku a pramenné hypotéze viz např. RENDTORFF, Rolf, 2000 s. 204-211. Či BIČ, Miloš, 1950, s. 175- 185.

4) Více k etnografii starověkého Izraele a jejímu idealizovanému obrazu viz kapitola „Israelite 'Idealized'Ethnography", KUNIN, Seth Daniel, 1995, s. 49-61.
Kontext

Přistup sociální a kulturní antropologie je charakterizován úsilím o objasnění jakéhokoliv kulturního/sociálního fenoménu v širším kontextu ostatních socio-kulturních aspektů dané kultury/společnosti. Základní otázky jsou: jaký je význam fenoménu, co symbolizuje a jak může být interpretován. Podívejme se tedy, jakým způsobem Ize $s$ tímto přistupem pracovat v našem případě, tedy v případě prvorozenectví v knize Genesis.

Starověký Izrael představoval komplexní hospodářskou společnost charak terizovanou dělbou práce a dálkovým obchodem, jež obojí podporovalo růst městských komplexů. Základní bohatství představovala zemědělská pưda a stáda. Otázka vlastnictví a dědictví mnohdy zpưsobovala problémy při udržování sociální kontinuity a jednoty společnosti. Obdobně jako v jiných zásadních záležitostech rod a rodina sloužily jako základní instituce pro řešení těchto problémů. Dědictví půdy a dalšího majetku bylo předáváno v rámci patrilinie a garantováno zvláštními dědickými zákony. Právn texty týkající se dědictví naznačují, že každá rodina ( $v$ ideálním případě) vlastní čás kmenové půdy, která je dále rozdělena mezi syny (či dědice) v každé generaci. Prvorozený syn obdrží jako své dědictví dvojitý podíl z majetku. ${ }^{5}$ Koncept prvorozenectví je v textu na mnoha místech předpokládán jako daný:

Kainova vražda Ábela mưže být spojena s Kainovým chápáním jeho práv jakožto staršího syna.

Izák hodlá udělit své požehnání Ezauovi.

Rúbenovo cizoložství s otcovou souložnicí mưže značit že Rúben očekává že on zdědí otcovu pozici.

Josef očekává, že Manases obdrži Jákobovo požehnání (KUNIN, Seth Daniel, 1995, s. 56, 106).

Nicméně dané pravidlo je neustále porušováno:

Izák a Jákob nejsou prvorození, přesto přejímají roli výhradních předkư Izraele na úkor svých vyděděných starších bratrů.

Výlučnost mladších synů můžeme sledovat $v$ dalších genealogiích, zjevně v prípadě Josefa, Efrajima a Manasese a v pozdějším cyklu Davida

5) Více k dědictvíprvorozeného viz BENDOR, Samuel, 1996, s. 175-188. 


\section{Interpretace}

Tyto zvláštní př́pady můžeme interpretovat několika různými způsoby. Zmíním pouze některé z nich:

Tyto transgrese mohou poukazovat na to, že pravidlo mělo pouze omezen užití a mohlo být převáženo darem či osobni vưli (SCHWIMMER, Brian, 1995). Transgrese mohou zdůrazňovat jiné preferované pravidlo - např. endogamii (uzavírání sňatků v rámci rodu), která pomáhá skupině posílit vlastní identitu a jedinečnost $v$ opozici k sousedním skupinám, se kterými je manželství zakázáno. Na nábožensko-symbolické rovině endogamie zaručuje čistotu lzraele, která dále zaručuje tomuto společenství Boží přizeň. Z tohoto úhlu pohledu pak někteří prvorození syni mohli být vyloučeni z následnictv a požehnání nebot' porušili endogamní pravidlo. Mưžeme se tak domnívat v případě Izmaela, syna Egypt’anky (zároveň i on si bere za ženu Egypt’anku) a Ezaua, který si bere za ženy Kenaanky. Jak vidno, vymezení Izraelitů jakož to vyvoleného lidu je tak spiše determinováno skrze proces lineální endogamie nežli skrze prvorozenectví.

Ještě pravděpodobněji tyto případy poukazují na připisování zvláštního statutu a moci kličovým postavám, významných natolik, že mohli porušit pravidla ve kterých obvykle nebyla povolena výjimka (SCHWIMMER, Brian, 1995).

V Izraelské tradici se zjevně setkáváme s dlouhou historii "mladších synü”, kteří v ní hrají důležitou roli. Tyto příklady pokládají chronologický precedent a případ ně slouží i jako literární vzorec pro pozdější přiběhy. Mohou také sloužit, v případě Davidovské monarchie, jako ospravedInění činů těch králů, kteří nahradili své starší bratry stejně jako byla nahrazena Saulova dynastie. Mohly také přispět k politické strategi $v$ době, kdy David přichází na trůn. Jak samotný David, tak jeho vojenský poradce Jóab se dopustí podvodu, stejně jako Jákob, aby zajistili úspěch svých plánů (viz 2 Sam. 3, $6-30 ; 15,32-37 ; 20,4-10)$

Zainteresování politické tradice do textu za účelem ospravedlnění pozdějších politických skutečností lze vidět i v př́běhu Josefa. Zde se nám do popředí dostávají dva majoritní kmeny, které budou dominovat politicky v pozdějších dějinách Izraele. Juda, zmíněný v príběhu v $G n 38$ a požehnaný $v$ Gn 49, 8 -12, a Efrajim, Josefưv mladší syn (Gn 48, 17 - 22), jsou označeni za budoucí vůdce (MATTHEWS, Victor H., 2002, s. 7 - 9). Většina vědců se shoduje na tom, že príběhy „mladších synư" ve formě starověkých legend ve skutečnosti odrážejí rivalitu v pozdní době královské. Pokud byly tyto př́běhy sepsány Judejci (nutno poznamenat, že mnoho poznámek proti severnímu království, které v textu nacházíme tuto domněnku potvrzují) mohou odrážet komplikovany postoj jihu k nadřazenému severu a ostatním národům (BRETTLER, Marc Zvi, 1995, s. 58).
Vezmeme-li si k ruce archeologické doklady začne se jevit tato interpretace ještě pravděpodobnějši. Dle Finkelsteina a Silbermana archeologický výzkum může prokázat, že Judsko do 8 . stol př. n. I. bylo spiše izolovaným a ř́dce osídleným královstvím v porovnání s větším a vojensky mocnějším Izraelským královstvím na severu. Nicméně po zničení severního království Asyřany v roce 720 př. n. I. populace v Judsku znatelně narostla, vznikly zde nové rozvinuté státní instituce a Judsko se tak dostalo do významné pozice $v$ regionu. Bylo spravováno starobylou dynastií a po pádu severního království se zde nacházel nejdůležitější chrám Boha Izraele. Proto na konci 8. stolet a ve století 7. př. n. I. bylo Judsko charakterizováno pocitem vlastní výjimečnosti a božiho predurčení - Bůh měl s Judskem své plány již od dob praotců. Na př́iběhy praotců, zahrnujicí jak starověké ústní tradice jihu, tak severu, zdưrazňujicí nadřazenost Judska bychom tedy měli nahližet jako na jakousi náboženskou „prehistorii" Izraele či je vníma jako literární pokus, jak znovu definovat jednotu izraelského národa (FINKELSTEIN, Is rael a Neil Asher SILBERMAN, 2007, s. $51-53$ ) ${ }^{6}$

\section{Závěr}

Přistup sociální a kulturní antropologie je užitečný při studiu archaických kultur a jejich náboženství v mnoha směrech. Síla antropologického rámce spočívá v tom, kolik nám toho může ř́ci o kontextuální povaze náboženského života a v tom, jak silné a rozmanité vztahy odhaluje mezi náboženskou a socio-kulturní identitou (PADEN, William, 2002, s. 58 - 59). Antropologické interpretace nabízejí pohled do „žitého" světa a poskytuji tak modely pro rekonstrukci minulosti a historických procesů obecně. Základní metodou je vytváření analogií. Úskalím je jejich často nekritický přenos bez jasně definovaného rámce. Mnohdy též není tou hlavní otázkou jak daný fenomén koresponduje se svým kulturním a historickým pozadím, ale jak by měl být interpretován. Další problém je spojen $s$ povahou pramenů, se kterými antropologie pracuje $v$ prípadě archaických náboženství. Zde mám na mysli především prameny textové.

Pokud se zaměříme na problematiku starověkého Izraele antropologie získává své informace téměř výlučně z hebrejské bible, mnohdy bez většího vědomí faktu že historická a etnografická přesnost a adekvátnost biblického textu je diskutabilní.

6) Je jasné, že v každodenni praxi mohlo docházet k porušování pravidel prvorozenectv' ze zcela praktických či zcela náhodných dưvodů. Nemuselo se tedy vždy jednat o ideologickou konstrukci. Vzhledem k tomu, že v našem prípadě však pracujeme s biblickým textem, s př́běhy sepsanými sjistým záměrem, myslím, že právě ona ideologická konstrukce je vhodným interpretačním nástrojem pro objasněni transgresív přibězich obsažených. 7) Viz Schwimmer a jeho z hlediska teorie príbuzenstvívelmi prínosný popis starověké izraelské společnosti, ovšem bez hlubšír reflexe historického pozadí (SCHWIMMER, Brian, 1997). 
Údaje v hebrejské bibli nám poskytuji hodnověrné obrazy pouze některých aspektů izraelské společnosti, kultury a náboženství - vesměs pokud „"čteme mezi řádky”. Nicméně texty $v$ hebrejské bibli, $v$ té podobě v jaké jsou nám $k$ dispozici mají tendenci být:

\section{- pozdního data \\ značně selektivní a silně editované \\ elitářské a idealistické}

zainteresované v teokratické ideologii; a

statické $v$ jejich finální podobě - žádné dalši texty se nepředpokládaj (DEVER, William G., 2002, s. 25 - 26).

Jedná se o jakousi "minority report”, revizionistickou historii sepsanou v tomto prípadě ne jako obvykle vítězi, ale „poraženými”, kteří v podstatě nikdy neměl výsadní postavení během doby království, kteří se ovšem stali nositeli literární tradice poté, co historie starověkého Izraele byla u konce (Ibid, s. 13).

Antropologický prístup by v tomto prípadě tedy měl být konfrontován nejen s prístupy z oblasti textové kritiky, ale i s archeologií. Hlavním důvodem je to, že archeologická data jsou:

- náhodná, needitovaná (dokud je my sami nezačneme editovat) a tudíž více reprezentuji širší společenské spektrum

populistická, reflektuji pozici většiny a běžné víry a praktiky

nasvědčuji více o sociálním chování než určitá ideologie

a jsou dynamická a potencionálně téměř neomezená (Ibid, s. 26).

Dle mého názoru takovéto interdisciplinární zkoumání a dialog může být ve lice prínosný a mưže nám poskytnout detailnějši, lépe vyvážený a uspokojivější obraz starověkého Izraele.

\section{Literatura}

Bible, Pismo svaté Starého a Nového zákona(1989): Praha: Ekumenická rada církvi ČSSR.

BENDOR, Samuel (1996): The Social Structure of Ancient Israel. Jerusalem: Simor Ltd.

BIČ, Miloš (1950): Palestina od pravěku ke krestanství. III. Řeč a pisemnosti. Praha: Husova československá evangelická fakulta bohoslovecká v Praze.

BRETTLER, Marc Zvi (1995): The Creation of History in Ancient Israel, London/New York: Routledge.

DEVER, William G. (2002): Theology, Philology, and Archaeology: In the Pursuit of Ancient Israelite Religion, in: Gittlen, Barry M., ed., Sacred time, sacred place: archeology and the religion of Israel, s. 11- 33
FINKELSTEIN, Israel - SILBERMAN, Neil Asher (2007): Objevování Bible. Svatá Pisma Izraele ve světle moderní archeologie. Praha: Vyšehrad.

KUNIN, Seth Daniel (1995): The Logic of Incest. A Structuralist Analysis of Hebrew Mythology. Sheffield: Sheffield Academic Press.

MATTHEWS, Victor H. (2002): A Brief History of Ancient Izrael. Lousville: Westminster John Knox Press. PADEN, William (2002): Bádáni o posvátnu. Náboženstvi ve spektru interpretací. Brno: Masarykova univerzita.

RENDTORFF, Rolf (2000): Hebrejská bible a dějiny. Úvod do starozákonní literatury. Praha: Vyšehrad.

SCHWIMMER, Brian (1995): Hebrew Lineage Organization: Inheritance [online]. O 1995 [cit. 2009-02-15]. Dostupné z <http://www.umanitoba.ca/faculties/arts/anthropology/tutor/case_studies/hebrews/inheri-

SCHWIMMER, Brian (1997): Family and Society in Ancient Israel [online]. @ 1997 [cit. 2009-02-15]. Dostupne z<http://www.umanitoba.ca/faculties/arts/anthropology/tutor/case_studies/hebrews/index. html>. 
David Rafael Moulis

\section{Jeruzalémský chrám v proměnách věku}

„Ačkoli jsou brány modlitby uzavreny, brány slz se neuzaviraji"

\section{Abstract}

This article describes more then 1.000 year's history of one of the most famous building in ancient Israel. King David made Jerusalem as the centre of his kingdom and he only prepaired the building plan. Later, his son Solomon built sanctuary for God's name. Architecture of the Jerusalem Temple was inspired in Mesopotamia. There wasn't any statue or image of God like in Mesopotamia, but inside in the Holy of holies was only the tabernacle. Jerusalem Temple was twice destroyed. For the first time by Nebuchadnezzar II in 586 BC and for the second time was destroyed by Romans in 70 CE. Before the second destruction the Temple was rebuilt by king Herod. Herod let extend temple area, expanded Temple and gave its new form. My work descirbes how the Temple and the Temple mount looked in many periods, at Solomon's time, at Cyrus's time, at Herodes's time and now. According to legends, from the Temple mount God took clay for creation of the first men Adam; there also went Abraham to sacrifice his son Isaac. That is the reason, why was this mount chosen as the place for the Jewish Temple. At the present time there is Dome of the Rock. 
Za jednu z nejskvostnějších a nejzajímavějších staveb všech dob může být označen již neexistujići Jeruzalémský chrám. Chrám byl centrem judaismu a celého tehdejšího Izraele. Určitě stojí za zmínku prípomenout, jaká že to byla stavba k oslavě Boha, jak vypadala, co skrývala uvnitř a jaký byl nakonec její osud, který byl pro celé židovstvo obrovskou tragédií a muselo se s ní patřičně vypořádat, aby mohlo přežít.

Už od mezopotamských dob je chrám sídlem božstva. Díky tomuto chápán příbytku má chrám shodný půdorys s obytnými domy. Bůh byl v mezopotamských chrámech reprezentován sochou, nebo jiným symbolem, který byl umístěn v nejsvatější části budovy. Tou byl menši prostor (i pódium nebo výklenek), na který navazovala hlavn místnost cella, kde se nacházel obětní stůl a kde probíhaly každodenní rituály. ${ }^{2}$ Před místností byl vstupní prostor (předsiň, hala), která byla spojujícím prostorem mezi chrámem a okolním světem. K základu svatyně často přiléhaly nejrůznější prostory a dvory. Součástí se někdy stával i odtok pro tekutiny z úliteb a obětin. Uvnitř chrámu byly lavice a plošiny pro dary. Stěny mnohdy byly zdobeny plastikami nebo maliřskými výjevy. Zároveň byly nalezeny skrýše s podobným významem jako je geníza v synagogách. Sloužily pro uchování již nepoužívaných kultovních předmětů. V severní Mezopotámii byl tradičním typem tzv. megaron. Šlo o podlouhlou místnost s vchodem na kratši strane budovy. Boční zdi u vchodu přesahovaly a vytvářely tak vestibul. Hlavní prostor neobklopovaly žádné menší postranní místnosti. Pokud se náhodou objevily, byl to vliv ze Sumeru. Stavby typu in antis se na Předním východě vyskytuji už od neolitu, ale teprve od 3. tis. př. obč. I. se o nich dá mluvit jako od chrámech. ${ }^{3}$ Chrámy typu in antis zdomácněly v severní Mezopotámii, Sýrii, jižní Malé Asii a v Palestině po roce 2000 př. obč. I. Hojně byly zastoupen až do 1. tis. př. obč. I. ${ }^{4}$ Některé starší asyrské chrámy jsou kombinací typu sumerského a typu in antis. Výsledkem této syntézy je, že vchod do chrámu není v ose budovy. Babylónský typ chrámu, který se objevoval od 3. a 2. tis. př. obč. l. až do seleukovské doby, měl pódium ve středu delší strany úzké místnosti, která byla vnitřní svatyní. Naproti pódiu byl vchod do hlavní místnosti. Tudiž sochu božstva na pódiu bylo možné zahlédnout v průhledu dveři. Na tyto dvě široké místnosti mohl být napojen dalši podobný objekt. Chrámy jsou od 4. tis. př. obč. I. stavěny na terasách a vyčnivaly tak nad okolními budovami i terénem. Úkolem chrámu bylo udržovat nepřetržitý liturgický

2) Cella - hlavní chrámová cást, vlastní svatyně, v niž je chován obraz božstva. Ottova encyklopedie obecných vědomostí. [online], [citováno dne 15.02.2009]. Dostupné z: <http://encyklopedie.seznam.cz/heslo/229272-cella>.

3) Chrám in antis mèl v průčelí piliriové výstupky (antae) zdí, obmykajicích cellu. Uprostřed mezi antami měl dva sloupy, nahoře pak štít. Antika. [online], [citováno dne 01.11.2008]. Dostupnéz: <http://antika.avonet.cz/article.php?ID=1496> 4) PROSECKÝ, Jiřri, et al. (1999): Encyklopedie starověkého Předního východu. Praha: Libri, str. 140-141. provoz. Uctívání božstva se skládalo z recitace nebo zpěvu posvátných textů, doprovázených hudbou a z přinášení obětí (většinou nekrvavých). Mimo to se v chrámech slavily svátky. O tyto úkony se starali specialisté - kněži. Mezopotamské chrámy byly také dějištěm recitací posvátných textů, hudby, zvuků dobytka, cinkotu stříbra, občanských jednání, proslovư, křiku mládeže a to všechno bylo podtrženo vưní kadidla. I významné obřady v životě se konaly zde. Do vyšších chrámových pozic se dosazovali panovníci a ti museli provádět různé kultovní pravomoci. ${ }^{5} \mathrm{O}$ bohy se muselo pečovat a bylo potřeba naklonit si je. Např́klad se do mezopotamských chrámů přinášely obětiny, které měly sloužit k nasycení božstva. U Izraelitů je Bůh rovněž nasycován, ale ne skrze fyzické potraviny, ale pomocí kouře z obětí a kadidla, který stoupal k Bohu. K světským aktivitám, které byly s mezopotamským chrámem spojeny patři například soustředování badatelů z oborů matematiky, prírodních a astronomických věd, pưsobení lékařů či věštcư. ${ }^{6}$

Jeruzalémský chrám nahradil stan setkání, který Izraelité stavěli na různých místech, kudy putovali. Hospodin v době putování Izraelitů pouští nepotřeboval ukotvený dům.

Král David dobyl kolem roku 1000 př. obč. I. jebusejské město - Jeruzalém a nechal do něho umístit nejposvátnější předmět Izraelitů, kterým nebylo nic jiného, než Archa úmluvy. S Archou se ve městě usadil i národ, který s ní putoval. David - sjednotitel Izraele a Judska z Jeruzaléma učinil politické centrum své ríše a zároveň kultovn centrum. Tento velmi zbožný král připravil výstavbu Chrámu, ale nebyl vhodný k tomu, aby ho vystavěl, nebot díky svým politickým krokům je označován za „válečníka a muže krve".? David vybral místo pro výstavbu svatyně, připravil stavební plány a nashromáždil prostředky. Samotná stavba proběhla až za vlády Davidova syna Šalomouna. Šalomounưv chrám byl monumentální, ale často si ho představujeme príliš megalomansky. Jak bude dále popsáno, rozměry Šalomounova chrámu nebyly až tak velké. Chrám nebyl vystavěn Bohu, ale pro Boží jméno, nebot̉ izraelský Bůh není fyzická postava a rozprostírá se všude. Chrám se tedy stal jednou a jedinou svatyní v celé zemi. Je zajímavé, že právě v době, kdy bylo cestování nebezpečné a drahé, bylo ustanoveno jediné poutn místo (ovládané Davidovskou dynastií), pro celý Izrael a Judsko. ${ }^{8}$

Otevřenou otázkou ale zůstává, na kolik byla centralizace kultu za Davida opravdu takto účinná a platná. Za jeden z důkazů, že vedle Šalomounova chrámu souběžně existovaly i jiné chrámy, můžeme považovat objevený chrám ve starověkém

5) Tamtéž, str. $141-142$

6) PROSECKÝ, Jiř́, et al. (1999): Encyklopedie starověkého Předniho východu. Praha: Libri, str. $141-142$.

7) GOLDHILL, Simon (2005): The Temple of Jerusalem. Massachusetts: Harvard Univer-

sity Press, str. 22. In: 1 Kr 5,17.

8) Tamtéž, str. 24-25. 
kanaánském a poté izraelském městě Arad. Samotný chrám je datován do 10. - 7. stol. př. obč. I. Měl shodné členěni prostoru jako Šalomounưv, včetně velesvatyně. K viděn je i oltář na obětním nádvoří a čtvercové základy dvou sloupů. Jen rozměry tohoto chrámu jsou poněkud miniaturní. Velikostně chrám připomíná větší obytný dům.

Bohatství na stavbu bylo nashromážděno ještě za vlády krále Davida, který porazil spousty národů a ty mu pak odváděly dávky. David ukořistil zlaté štíty a jiné zlaté či měděné předměty. Všechny zlaté, střibrné a měděné předměty od podmaněných národů dal David zasvětit Hospodinu. ${ }^{9}$ Některé národy přinášely králi dary dobrovolně. Když byl Šalomoun pomazán za krále, Davidův přitel Chíram z Týru mu vyslal na základě Šalomounova vzkazu své služebníky. Protože Šalomoun nebyl vojensky ohrožován a Hospodin mu dodal klid, rozhodl se, že vybuduje Chrám jménu Hospodinovu. Šalomounův chrám se stal po staletí modelem jiným chrámům v celém středomoří. Popis plánu je uveden v Knihách Královských. Tyto knihy byly sepsány až po zničení Chrámu, jako připomenutí jeho velkoleposti. Chíram přislíbil, že dodá cedrové a cypřišové dřevo z Libanonu. Šalomoun Chíramovi na oplátku slíbil, že bude živit jeho dům a tak mu posilal pšenic a olej. Král vybral z celého Izraele 30 tisíc dělníků. Každý měsíc jich vysílal 10 tisíc do Libanonu, kde se střídali. Šalomoun měl k dispozici rovněž 70 tisíc nosičů břemen, 80 tisíc kameníků a 3300 dohližitelů. ${ }^{10}$ Protože Šalomounův chrám byl nevelkých rozměrů ( $60 x$ 20 × 30 loktư) jsou údaje o počtech dělníkư dosti nadsazené. Př́ičinou může být nepřesný překlad slova „elef”, které znamená jednak "tisíc” a také „oddíl”. Z toho vyplývá, že místo 30 tisíc dělníků se mohlo jednat o 30 oddílů dělníků a to už jsou čísla reálná.

Stavba byla započata ve druhém měsíci 480 let po vyjití Izraelitů z Egypta. Při stavbě nesměly být použity žádné železné nástroje. V úvahu nepřicházelo kladivo nebo dláto a veškerý kámen se opracovával již v lomu. Obdélníkový pưdorys byl rozdělen na tři části: ulam, hejchal a dvir. Náboženské svatyně s podobným pưdorysem byly archeology nalezeny $v$ Kanaánu a v Sýrii. ${ }^{11}$ Půdorys zároveň odpovídal svatostánku a stanu setkání, který Izraelité použivali při putování pouští. Každou noc byla Archa úmluvy umístěna do svatostánku a Izraelité kolem utvořili pravidelný obdélníkový tábor. Podobně jsou rozmístěni lidé na obdélníkovém nádvoří kolem Chrámu. ${ }^{12}$ Předn část stavby (ulam) sloužila jako předsiń či vestibul a její délka byla 20 loktů. Hejchal se dá přeložit jako palác, ale použivá se i termín dům. Byl dlouhý 40 loktů a nacházela se v něm okna se zužujícím se ostěním. Uvnitř hejchalu bylo všechno z cedru (kalichy květů

9) $158-9$

10) $1 K r 5,15-28$.

11) GOLDHILL, Simon (2005): The Temple of Jerusalem. Massachusetts: Harvard University Press, str. 28

12) GOLDHILL, Simon (2005): The Temple of Jerusalem. Massachusetts: Harvard University Press, str. 31 a věncoví z květin), takže holý kámen nebylo možné vưbec spatřit. Byl zde umístěn i cedrový oltář, který byl také obložen zlatem. Nakonec byl celý hejchal obložen zlatem Kolem dokola hejchalu a dviru byla vybudována přistavba, čímž vznikly ochozy. Přistavba byla ve spodní části široká 5 loktů, ve střední 6 a v horní 7 loktů. výška její každé části byla vždy 5 loktů a celkem tedy 15 loktů. Točité schody sloužily k výstupu na střední ochoz a ze středního pokračovaly na třetí. Na vnější zdi domu byly dokola římsovité výstupky, aby stropní trámy nezasahovaly do zdí. Trámy byly z cedrového dřeva stejně jako vnitřní obložení od podlahy až ke stropu. Podlahy pokrývaly cypřišové desky. Dvacet loktů od zadní strany Chrámu Šalomoun nechal vybudovat přepážku z cedrových desek od podlahy až ke stropu, čímž vznikla část dvir (velesvatyně, svatyně svatých). Před přepážkou byly zlaté řetězy. $V$ dviru byla uložena Schránka Hospodinovy smlouvy. Pod víkem s cheruby se v Arše měly ukrývat desky s Desaterem, miska s manou a Áronova hůl. Dvir byla krychle o rozměrech $20 \times 20$ × 20 loktů. Stěny byly obloženy lístkovým zlatem. Uvnitř dviru byli dva naprosto stejní cherubové z olivového dřeva, každý o výšce 10 loktů. Jejich každé kř́idlo měřilo 5 loktů. Křídla byla rozprostřena tak, že jedno kř́dlo prvního cheruba se dotýkalo stěny dviru, stejně jako jedno křídlo druhého cheruba. Jejich druhá kř́idla se navzájem dotýkala uprostřed místnosti. I tito cherubové byli obloženi zlatem. Přední i zadní stěny nesly dokola vyřezané cheruby, palmy a věncov z květin. Stěny i podlaha byly obloženy zlatem. Vchod do dviru byl opatřen dveřmi z olivového dřeva. Obě křídla dveří byla z olivového dřeva a opět na nich byli vyřezávaní cherubové a palmy a věncoví obložené zlatem. Piliř a veřeje byly pětihranné. Podobné veřeje byly před vstupem do hejchalu, ale jen čtyřhranné. Dveře vyrobené z cypřišového dřeva měly každé kř́ídlo dvojdílné a otáčelo se. Výzdoba dveří byla totožná s těmi do dviru. Zed' vnitřního nádvoři byla vybudována ze tř́ vrstev kamenných kvádrů a z jedné vrstvy cedrových trámů. Touto zdí byl oddělen posvátný prostor od veřejného. Tak byl dostavěn Šalomounův chrám po sedmi letech. S výstavbou se začalo ve čtvrtém roce vlády krále Šalomouna ( $v$ měsíci zivu) a vše bylo dokončeno v jedenáctém roce jeho vlády (v měsíci búlu) ${ }^{13} \mathrm{~K}$ výrobě vybavení Chrámu povolal Šalomoun Chírama z Týru - řemesIníka obrábějícího měd. Vytvořil dva bronzové sloupy Boaz a Jachin, každý o výšce 18 loktů. ${ }^{14}$ Ty stály před vchodem do předsíně. Bronzové hlavice byly nasazeny na sloupy a jejich výška byla 5 loktů. Na hlavicích bylo proplétané mřižování s řetízkovými ozdobami. Na každé hlavici jich bylo 7. Ke každému sloupu Chíram vyrobil dvě řady granátových jablek kolem každého mřížování. Granátových jablek bylo celkem 200. Hlavice byly zakončeny liliii 4 lokty vysokou. Chíram vyrobil i tzv. moře. Byla to okrouhlá měděná nádrž, která sloužila k očištování kněži. Její průměr byl 10 loktů a objem $720 \mathrm{hl}$.

13) $1 \mathrm{Kr} 6,1-37$

14) „Boaz" = v něm je silla ${ }_{i}$ jachin” = on upevní. In: Bible : Písmo svaté Starého a Nového zákona. Ekumenická rada církvív ČSSR. Praha : Tisk, 1989, str. 293. 
Pod jejím okrajem bylo ve dvou řadách věncoví. Nádrž stála na dvanácti měděných býčcích, kdy na každou světovou stranu směřovali 3 z nich. Jejich zadní části těl směřovaly ke středu dovnitř. 10 bronzových stojanů o šiřce 4 lokty a o výšce 3 lokty na další nádrže tvořily lišty spojované príčkami. Na lištách byli znázorněni Ivi, býčci a věnce. Stojan mě vždy 4 kola a nesI nádrž sloužicí k omývání oběti. ${ }^{15}$ Stojany měly držadla s vyrytými cheruby, lvy a palmami. Na každé straně Chrámu z venku stálo 5 těchto stojanů s nádržemi. Moře stávalo po pravé straně Chrámu k jihovýchodu. Mezi drobnější výrobky Chírama patřily kotlíky, lopatky a kropenky. ${ }^{16}$ Všechny tyto předměty z leštěného bronzu se odlévaly do země v jordánském okrsku mezi Sukotem a Saretanem. ${ }^{17}$ Šalomoun uděla všechny předměty určené pro Chrám. Byly jimi: zlatý oltář, zlatý stůl pro předkladný chléb, svícny potažené lístkovým zlatem ( 5 napravo a 5 nalevo $v$ hejchalu před velesvatyní), s jejich květy, kahánky, kleště na knoty, misky, nože, kropenky, číše a pánve.

Šalomoun uložil do hotového Chrámu svaté dary svého otce. Po dokončen prací nechal svolat shromáždění starších. Když všichni kněží dorazili, vynesli Schránku úmluvy do velesvatyně pod kř́dla cherubů, společně se stanem setkání a s předměty, které v něm byly. ${ }^{18} \mathrm{Když} \mathrm{kněží} \mathrm{z} \mathrm{Chrámu} \mathrm{vyšli,} \mathrm{zahalil} \mathrm{ho} \mathrm{oblak,} \mathrm{nebot'} \mathrm{Hospodinův} \mathrm{dưm}$ naplnila Jeho sláva. ${ }^{19}$ Na nádvoří kolem Chrámu se konaly náboženské ceremonie. Stál zde bronzový oltář o rozloze $10 \mathrm{~m}^{2}$ se stoly pro chléb a jiné oběti. ${ }^{20} \mathrm{Chrám}$ byl navštěvován o třech poutních svátcích. ${ }^{21}$

Podle tradice nechal král Šalomoun postavit i dvě brány - pro novomanžele a pro truchlící a exkomunikované. Izraelci si o Šabatu sedávali mezi tyto dvě brány a nacvičovali si schopnost benevolence tak, že když Branou novomanželů vstoupil nějaký muž, bylo jasné, že se brzy ožení a Izraelci mu žehnali: „At’ Hospodin tohoto domu ti udělá radost v mnoha synech a dcerách!" Pokud někdo vešel Branou truchlících Izraelci mu pravili: „At' tě Hospodin tohoto domu utěši! "²2

15) Objem každé nádrže byl 1440

16) $1 \mathrm{Kr} 7,13-39$

17) $1 \mathrm{Kr} 7,45-46$.

18) $1 \mathrm{Kr} 8,1-6$.

19) $1 \mathrm{Kr} 8,10$.

20) GOLDHILL, Simon (2005): The Temple of Jerusalem. Massachusetts: Harvard University Press, str. 30

21) Talmud Bavli: Chagiga 1,1.

22) VILNAY, Zev (2000): Legendy Jeruzaléma. Praha: Volvox Globator, str. $89-90$.

In: Pirkej Rabi Eliezer 17 a Masechet Sofrim 18,9.
Šalomoun na Chrámové hoře vybudoval také palác z ušlechtilého kamene sobě i své manželce - dceři faraóna. $V$ Šalomounově domě ( 100 x 50 loktů) byla i trưnn siň, kde soudil. Výstavba budov mu trvala 13 let. ${ }^{23}$

Za vlády judského krále Joáše (835 - 796 př. obč. I. ) byl Chrám poškozen zubem času. Joáš ve dvacátém třetím roce své vlády nařídil, aby střibro, které lidé přinesou do Hospodinova domu, bylo určeno na opravu poškozených částí Chrámu. Kněz Jójada vyrobil z truhly kasu a postavil ji napravo od vchodu do Chrámu a všichni do $n$ přinášeli stříbro. Když byl v truhle dostatek stříbra, začalo se s opravami. Stavitelé, řemesIníci a dohližitelé byli placeni právě z nastřádaného stříbra. Žádné vyúčtování nebylo potřeba, nebot' všichni jednali čestně. ${ }^{24}$

Chrám sloužil svým účelům až do dobytí Jeruzaléma v roce 587 př. obč. I. a do následného zničení Chrámu v roce 586 př. obč. I. babylonskými vojsky v čele s králem Nabukadnesarem II. Tisíce Židů byly odvlečeno do Babylónie (jednalo se o tzv. babylónské zajetí). Když v roce 539 př. obč. I. perský král Kýros dobyl Babylon, už v prvním roce své vlády (538 př. obč. I.) vydal edikt, dovolujicí Židům návrat do jejich vlasti a zároveň vydal rozkaz k obnově Chrámu v Jeruzalémě. Už téhož roku dorazili do Judska první navrátilci. Kýros pravil:

„Hospodin, Bůh nebes mi dal všechna království země. Pověril mě, abych mu vybudoval dům v Jeruzalémě, který je v Judsku."25

Babylóňané měli Židy podpořit střibrem, zlatem a dobytkem pro dobrovolné oběti Bohu v Jeruzalémě. Král Kýros také vrátil předměty, které ukořistil Nabukadnesar II. v Šalomounově chrámu a dal je do domu svého boha. ${ }^{26}$ Všech takových předmětů bylo celkem $5.400 .{ }^{27} \mathrm{Když} \mathrm{se} \mathrm{všichni} \mathrm{Izraelité} \mathrm{usadili} \mathrm{ve} \mathrm{svých} \mathrm{městech,} \mathrm{shromáždil} \mathrm{se}$ $\checkmark$ Jeruzalémě lid. Mezi nimi byl Jéšua s bratry a kněžími a Zerubábel s bratry. Ti se rozhodli, že znovu vybudují oltář pro zápalné oběti na jeho pưvodním místě, aby mohli obětovat Bohu, protože měli strach z okolních národů. Podle povolení Kýra se opět začalo dopravovat cedrové dřivi z Libanonu do Jafy. ${ }^{28}$

S obnovou Chrámu se začalo v roce 520 př. obč. I. a stavělo se 5 let. Staviteem byl ustanoven Zerubábel, proto je Druhý chrám rovněž označován za Zerubábelův. Výška Druhého chrámu měla být větší než u Šalomounova chrámu - 60 loktů a šířka

23) $1 \mathrm{Kr} 7,1-9$.

24) $2 \operatorname{Kr} 12,5-16$

25) 2 Pa 36,23 .

26) Zde je uvedeno úmyslněbůh, nebot'je myšlen jeden z mnoha z babylónského panteonu. 27) Ezd 1.

28) Ezd 3,1-4. 
také 60 loktů. Půdorys měl být stejný jako u Šalomounova chrámu. ${ }^{29}$ Otázkou je, zda byly použity pưvodní základy, nebo byla stavba posunuta. Minimálně je reálná myšlenka, že mohly být použity kameny z ruin zbořeného Chrámu. Tím mohlo být sniženo potřebné množství těženého kamene. ${ }^{30}$ Zajímavou, ale ne př́liš kvalitně podloženou myš lenkou je, že v Ezd 4,12 a 5,16 je pro označení základu (Chrámu) použito slovo "Ušaja”, které bylo přejato ze sumerštiny přes akkadštinu. ${ }^{31} \mathrm{D}$. Edelman na základě tohoto slova použitého při položení základů Druhého chrámu uvádí, že je možné, že Chrám byl založen (nebo jeho základy postaveny) podle mezopotamských tradic. V Mezopotámii byla u chrámů vytvořeno terasa z navážky a suti kvưli minimálnímu skalnatému podloží. Sut vyplňovala prostor mezi silnými zdmi. Teprve na této terase byla vybudována podlaha. ${ }^{32}$ Zerubábelův chrám měl mít tři vrstvy stěn z kamenných kvádrů a jedna vrstva měla být tvořena z nových trámů. Náklady byly hrazeny z královské pokladny Kýra a jeho následovníka Dareia. Chrám byl dostavěn v šestém roce kralování krále Dareia (515 př. obč. I. ). ${ }^{33}$

Když se dostal k moci Herodes v roce 37 př. obč. l., rozhodl se, že celý Chrám zvelebí. Potřeboval udržet ve své oblasti klid. Chtěl si naklonit Židy a zároveň potřeboval mít dobré vztahy s Římem, konkrétně s Markem Antoniem - pravou rukou Julia Césara. Díla, kterými si chtěl tuto pozici udržet byla jednak přestavba Chrámu v Jeruzalémě a pak jím byla výstavba prístavního města s paláci, divadlem, hippodromem nazvaného jednoduše a jasně - Caesarea. Finance na přestavbu Jeruzalémského chrámu nemohl Herodes získat nikde jinde, než na poplatcích od Židů. Omezil roli Sanhedrinu a oslabil funkci velekněze. ${ }^{34}$ Herodes začal nejdřive s rekonstrukcí veřejných prostor Jeruzaléma a pak se teprve vrhl na Chrám. Chtěl z něho udělat největší stavbu v Římské řiši. ${ }^{35}$ Přestavba byla zahájena v roce 19. př.o.I. rozšiřením chrámového okrsku a jeho podepřením. Nejmenší rozlohu měl okrsek v době Šalomouna a naopak největší za vlády

29) GOLDHILL, Simon (2005): The Temple of Jerusalem. Massachusetts: Harvard University Press, str. 47.

30) EDELMAN, Diana (2005): The Origins of the, Second' Temple: Persian Imperial Policy and the Rebuilding of Jerusalem. London, Equinox, str. 156.

31) "Ušaja" hebrejsky základ (stavební); akkadské označeni pro základ: „išdum” nebo "UŠšum".

32) EDELMAN, Diana (2005): The Origins of the, Second' Temple : Persian Imperial Policy and the Rebuilding of Jerusalem. London: Equinox, str. 156.

33) Ezd 6.

34) V římské době byl Sanhedrin nejvyšším politickým, náboženským a soudním orgánem v Palestině. Encyclopaedia Judaica. CD-ROM verze. Heslo: Sanhedrin.

35) GOLDHILL, Simon (2005): The Temple of Jerusalem. Massachusetts: Harvard University Press, str. 58
Heroda (cca $279 \times 466 \times 315 \times 487$ m). ${ }^{36}$ Zdi bylyz jeruzalémského vápence, který se těžil nedaleko. Kvádry nebyly spojovány maltou. Herodes nechal objednat tisíc vozů, které kameny převážely. 10 tisíc zkušených dělníků včetně kněží mělo na starosti stavbu. Bylo potřeba, aby Chrám zasvěcený Hospodinovu jménu, byl postavena posvátnýma rukama s veškerou pietou a aby vše bylo dle predpisů..$^{37}$ Jednotlivé kvádry ve zdi byly obrovských rozměrů. Nejmenší bloky hradby váži mezi $2-5$ ti tunami, ty větší kolem 50 ti tun a ten největší váži 400 tun a má rozměry $12 \times 3 \times 4$ metry. Část z této hradby se dochovala jako jediný pozůstatek z celého komplexu a je známa pod názvem Západní zed' (Zed’nářkư). $\mathrm{Na}$ Chrámovou horu se vstupovalo 5ti branami. Poutníci vstupovali do západní zdi a pak pokračovali podél podzemních galerií a nakonec doslova šplhali po schodech na chrámový okrsek. Všechny 4 strany okrsku byly lemovány sloupovým o třech patrech. Výška prưčelí samotného Chrámu byla podle moderních učenců cca 50 metrů. Kolem celého Chrámu bylo sloupové zábradlí a mřižové oplocení o výšce 2 metry, které vyznačovalo posvátnou oblast. Na zábradlí byly v latině a řečtině pokyny, zakazující vstup pohanů do těchto prostor pod trestem smrti. Dva z těchto řeckých nápisů byly nalezeny. ${ }^{38}$ Součást chrámového okrsku byly i obchodní prostory, kde bylo možné zakoupit obětní zviřata. Byla to taková citadela s 34 cisternami na vodu a akvaduktem. Na nádvoří préd zábradlím byl Dvưr pohanů, odkud mohl kdokoliv sledovat obřady. Hned za zábradlím byl Dvư pro židovské ženy. Z Dvora žen se vstoupilo na Dvưr Izraelitů, kam měli přístup jen rituálně čistí židovští muži. V predu u Chrámu byli Kohéni a kněží. Zde stál i obětní oltář a umyvadlo k rituálnímu očištění. Kolem tohoto nádvoří byly různé místnosti pro prípravu zviřat k obětování a sklady dřeva, vody a ohně. Tyto rituální věci byly přinášeny branami, které nesly jméno podle dané suroviny. Například Brána plamene, Brána vody, Brána obětí a další. ${ }^{39}$ Rozčleněni vnitřních prostor Chrámu bylo stejné jako u Šalomounova chrámu. Velesvatyně byla prázdným místem, kde měl být naprostý klid. Do prostřední část hejchalu vedly obrovské zlaté dveře, na nichž byly ozdoby ze zlatých hroznü větších než člověk. Podle traktátu Middot se stala nehoda a muselo být povoláno 300 kněží, aby tak těžké hrozny uzvedlii. ${ }^{40} \mathrm{~V}$ hejchalu byl sedmiramenný svícen (menora) a stoly pro předkladný chléb. Před vstupem do velesvatyně před zlatými dveřmi (20 metrů

36) REIDINGER, Erwin. (2005): Die Tempelanlage in Jerusalem von Salomo bis Herodes: Neuer Ansatz für Rekonstruktion durch Bauforschung und Astronomie. Wiener Neustadt: Erweiterter Nachdruck, str. 3 a 9 .

37) GOLDHILL, Simon (2005): The Temple of Jerusalem. Massachusetts: Harvard University Press, str. 60

38) GOLDHILL, Simon (2005): The Temple of Jerusalem. Massachusetts: Harvard University Press, str. 68.

39) Tamtéž, str. 70.

40) Talmud Bavli: Middot 3:8 
vysokými) visela opona (parochet) - babylonský gobelín. Jeho barvy měly jasnou symboliku: modrá (nebe), červená (oheň), fialová (voda) a pruhy (země). ${ }^{41}$

Sláva tohoto Herodova chrámu trvala jen krátce a to do roku 70 obč. I., kdy byl zničen 9. avu, ve stejný den jako první - Šalomounův chrám.

Od roku 691 obč. I. na chrámové hoře stojí Skalní dóm neboli Omarova mešita vybudovaná chalífou Abd el-Malikem.

\section{Legendy o Jeruzalémském chrámu}

"Sedm věcí bylo stvořeno před tím, než byl stvořen svět. Jsou to: Tóra, pokání, ráj, gehinom, trůn slávy, Chrám a jméno Mesiáše." "42 Pět výtvorů vlastní Svatý, budiž pochválen a mezi nimi je i Tóra a Chrám. ${ }^{43}$ Hora, která byla vybrána pro výstavbu Chrámu nesla méno Moria a též je známa pod názvem Sijón. Jedna legenda odvozuje jméno od hebrejského slova mor (myrha). Po celé Hoře se totižz linula vưně kadidla z Chrámu. Tak jedním výkladem je, že Moria znamená Myrhová hora. ${ }^{44}$ Další možností je odvozenina od slova or (světlo). Prý, když byl stvořen svět, první paprsek světla ozáril lidstvo právě $z$ této hory (Hory světla). ${ }^{45}$ Také přichází v úvahu označení Hora vzdělanosti. Hebrejské more (učitel), má stejný kořen , jako je ve slově Tóra. $Z$ této hory se rozšírilo učení Tóry a zákona Izraele. ${ }^{46}$ Existuje celá řada dalších legend, vysvětlujicí název tohoto „posvátného pahorku". Jsou jimi například Hora úcty, Hora koření, Hora výměny a mnohé další.

Podle tradice se v Chrámu nacházel základní kámen celého světa (Even haštija), na kterém byl založen svět a odsud pak byla dotvořena země. ${ }^{47}$ Svatá země muse la být stvořena jako první, a právě v sídle Chrámu - na nejsvětějším místě musel být započat proces stvoření. ${ }^{48}$ Právě odtud vzal Hospodin hlínu, když tvořil prvního člověka Adama. Adam a jeho synové pak na toto místo chodili přinášet Bohu oběti. I príběh o obětování Izáka Abrahámem, kde se hovoří o zemi Moria se měl odehrát na této hoře. ${ }^{49}$ Jak je známo, Hospodinův posel zasáhne a obětování lzáka neproběhne. Také Noe

41) GOLDHILL, Simon (2005): The Temple of Jerusalem. Massachusetts: Harvard University Press, str. 72

42) "Gehinom" - označení „pekla”. Talmud Bavli: Pesachim 54a

43) COHEN, Abraham (2006): Talmud: Pro každého. Praha: Sefer, str. 175.

44) VILNAY, Zev (2000): Legendy Jeruzaléma. Praha: Volvox Globator, str. 60. In: Gn 22,2. 45) Tamtéž, str. 60. In: Berešit Raba 3,4 a Ezechiel 43,2.

46) VILNAY, Zev (2000): Legendy Jeruzaléma. Praha: Volvox Globator, str. 61. In: Izajáš 2,3. 47) Talmud Bavli: Joma 546.

48) COHEN, Abraham (2006): Talmud: Pro každého. Praha: Sefer, str. 68 49) $G n 22$. po opadnutí vod jako první přichází na stejné místo, jako Adam, aby přinesl smírči obět' Syn Noemův Šém, pohřbí nedaleko Adamovu lebku. Toto místo pak dostává název Golgota (Lebka)..$^{50}$ Hora Moria je místem, kde o sobě dával Bůh vědět a tak byla tato Hora chápána jako Jeho sídlo.

Podle další z legend na vrcholku hory Morija, kde stával Chrám, ležel již zmíněný základní kámen, na němž bylo vytesáno Boží jméno. Když prý král David hloubil základy pro Chrám, tento kámen nalezl a položil ho do svatyně svatých. Mudrci měl obavy, aby někdo tento kámen nenašel a pomocí Božího jména nezničil svět. Aby se tomu nestalo, vyrobili dva mosazné lvy, které umístili na sloupy u dveři svatyně svatých. Pokud by někdo vstoupil dovnitř a Boží jméno by zjistil, lvi by na něho při odchodu tak zařvali, že by dotyčnému jméno z hlavy navždy vypadlo. ${ }^{51}$

Při samotné stavbě, nebo spíše přestavbě Chrámu za Heroda pršelo pouze $\checkmark$ noci a ráno se zvedl vítr, který rozfoukal mraky a vyšlo slunce. Sám Hospodin nechtě rušit dělníky při stavbě Jeho Chrámu. ${ }^{52}$ Herodův chrám byl podle Talmudu ze žlutého a bílého mramoru (možná ještě navíc i z modrého). Herodes prý chtěl mramor zakrýt zlatem, ale rabíni mu to rozmluvili. Takto prý Chrám vypadal jako mořské vlny a byl i hezčí. ${ }^{53}$

I k předmětům z Chrámu existují legendy. Archa úmluvy a ostatní nádoby jsou zakopané a zapečetěné ve Studni duší pod jeskyní základního kamene v dnešním Skalním dómu. ${ }^{54}$ Podle Josepha Flavia byla spousta předmětů z Druhého chrámu odve zena do Říma a uložena v paláci císaře. Rabi Josi, který ve 2. stol. obč. I. navštívil Řím, tam prý viděl závěs a bylo na něm několik kapek krve. Ta se na něm objevila, když Titus $v$ Jeruzalémě tento závěs rožrízl a krev z něho vytryskla. Titus si tak myslel, že zabil samotného Boha ${ }^{55}$ Jeden ze svícnů Chrámu se prý ještě v 9. stol. obč. I. zapaloval v Konstantinopoli. Podobně se traduje, že jeden bronzový svícen v Chrámu sv. Víta v Praze pochází z Jeruzaléma a do Prahy se dostal jako kořist z bitvy v Itálii v r. 1158 o.l. ${ }^{56}$ Zlaty květ z ryzího zlata, na němž bylo vyryto: "Svatý Hospodinu”, byl podle Tóry umístěn na koruně velekněze. Tento předmět byl odvezen spolu s chrámovou kořistí do Říma a tam

50) VILNAY, Zev (2000): Legendy Jeruzaléma. Praha: Volvox Globator, str. 64. In: Midraš Tehilim 92,6.

51) Tamtéž, str. 14 a 17

52) Tamtéź, str. 72. In: Talmud Bavli: Taanit $23 a$

53) Tamtéž, str. 72 - 73. In: Talmud Bavli: Suka 51b, Bava Batra 4a a Šemot Raba 36,1.

54) Tamtéž, str. 108.

55) VILNAY, Zev (2000): Legendy Jeruzaléma. Praha: Volvox Globator, str. 108. In: Josephus Flavius Válka židovská VII 8,7. Tosefta, Jom Ha-Kipurim 3,8 a Talmud Bavli: Gitin 56b, Suka $5 a$

56) Tamtéž, str. 109. In: Talmud Jerušalmi Šekalim 6,1. REJ, XIII, 1888, str.55. 
ho rovněž spatřil Rabi Eliezer. ${ }^{57} \bigvee$ Římě se mají nacházet i některé sloupy z Chrámu. ${ }^{58} \mathrm{Již}$ zmíněný Rabi Eliezer tam údajně viděl i úlomky Šalomounova trůnu. Ten byl odvezen postupně do Babylonu, Persie, Řecka a nakonec do Říma. ${ }^{59}$ Jako poslední legendu jsem vybral tu, podle niž se lampy a svice ve Skalním dómu, sloužíí lidem k večerním modlitbám večer o 9. avu, kdy byly zničeny oba chrámy, samy zhasínají a nejdou znovu zapálit.. ${ }^{60}$

Závěrem bych rád zmínil, že existují myšlenky o obnově Chrámu, který je nazýván podle Ezechiela, z jehož biblické knihy vychází. To, jestli tento projekt bude někdy zrealizován a jak by byl řešen prakticky, odkryje budoucnost. Místem, které do určité míry supluje a může připomenout Chrám, je dům setkání - synagoga. V synagoze nejdeme rozděleni prostoru do třech hlavních částí: místo pro věrící, prostor pro předčitání z Tóry (bima či almemor) a místo, kde je ukryta Tóra ${ }^{61}$ Tóra je za nádherně zdobenou oponou, podobně jako byla Archa úmluvy. Áron ha-kodeš je často po stranách obklopen dvěma sloupy, jejichž motiv se opakuje a připomíná dva slavné sloupy před Chrámem - Jachín a Boáz. prostor pro věríí je rozdělen na mužskou a ženskou část. Podobných paralel by se dalo najít mnohem více, ale to už může zkusit každý sám.

\section{Literatura}

Bible : Písmo svaté Starého a Nového zákona. Ekumenická rada církvi v ČSSR. Praha : Tisk, 1989. 1149 s. COHEN, Abraham. Talmud: Pro každého. 1. vyd. Praha: Sefer, 2006. $479 \mathrm{~s}$

EDELMAN, Diana. The Origins of the, Second' Temple: Persian Imperial Policy and the Rebuilding of Jerusalem. 1st edition. London: Equinox, 2005.440 s.

GOLDHILL, Simon. The Temple of Jerusalem. Massachusetts: Harvard University Press, 2005. $194 \mathrm{~s}$.

HORÑANOVÁ, Sidonia. Synagógy: Kontinuita medzi SYNAGÓGÉ a EKKLÉSIA. 1. vyd. Bratislava : Vydavatel'stve UK, 20

HUEHNERGARD, John. A Grammar of Akkadian. Atlanta: Georgia, 1996

CHARLESWORTH, James H. The Messiah. Minneapolis : Fortress Press, c1992. 5975.

KLEIN, Ernest. A Comprehensive Etymological Dictionary of the Hebrew Language for Readers of English Jerusalem: Carta, $1987.721 \mathrm{~s}$

NEUSNER, Jacob. The Mishnah: a new translation. New Haven : Yale University Press, c1998. $1162 \mathrm{~s}$.

NEWMAN, Ja'akov, SIVAN, Gavri'el. Judaismus od A do Z. 1. vyd. Praha : Sefer, 1998. $285 \mathrm{~s}$

PÍPAL, Blahoslav. Hebrejsko-českýs slovník ke Starému zákonu. 4. vyd. Praha : KALICH, 2006. $188 \mathrm{~s}$.

PROSECKÝ, Jiři, et al. Encyklopedie starověkého Předniho východu. 1. vyd. Praha : Libri, 1999. 447 s.

57) Tamtéž, str. 109. In: Exodus 28,36; 39,30 a Talmud Bavli: Suka $8 a$.

58) Tamtéż, str. 109. In: Berešit Raba 33,1.

59) VILNAY, Zev (2000): Legendy Jeruzaléma. Praha: Volvox Globator, str. 110. In: Ester Raba 1,10

60) Tamtéž, str. 37. In: Ocar Massaot str. 100, 121

61) „Aron ha-kodeš” - hebrejsky „svatá skřin"”.
REIDINGER, Erwin. Die Tempelanlage in Jerusalem von Salomo bis Herodes : Never Ansatz für Rekonstrukton durch Bauforschung und Astronomie. Wiener Neustadt : Erweiterter Nachdruck, 2005. $83 \mathrm{~s}$. SIMONS, Jan Jozef. Jerusalem in the Old Testament: researches and theories. Leiden : E. J. Brill, 1952. 517 s. TYDLITÁTOVÁ, Věra. Stromy ve starozákonní tradici. 1. vyd. Středokluky: Zdeněk Susa, 2008. 246 s. VILNAY, Zev. Legendy Jeruzaléma. 1. vyd. Praha : Volvox Globator, 2000. $287 \mathrm{~s}$.

Použité elektronické texty

Encyclopaedia Judaica, (ed,) Geoffrey Wigoder, [CD-ROM] Judaica Multimedia (Israel) Ltd. 2004

\section{Použité online zdroje informaci}

Ottova encyklopedie obecných vědomosti. [online], [citováno dne 15.02.2009]. Dostupnéz: <http://encyklopedie.seznam.cz/heslo/229272-cellar.

Antika. [citováno dne 01.11.2008]. Dostupné z: <http://antika.avonet.cz/article php?|D=1496>. 
Vlastimil Novák

\section{Detektory kovů jako nástroje revize nálezů mincí: Kelčský prípad islámského stříbra}

\section{Abstract:}

The Kelč hoard (1938, Valašské Meziř́čí district, Moravia) has been revised. Some new material was discovered at the same locality (about 2000) via metal detecting activities (27 denarii of the cross type and the Otto-Adelheid type, 233 fragments of various European denarii, 345 fragments of Islamic coins, 6 unidentified coin fragments and 61 fragments of silver jewelry). In 2008, also using metal detectors, two complete denarii (one fragmented), plus one fragment of denarius and one Islamic fragment were found there. The textile frag ments found together with the coins, their fragments and the fragments of silver jewels have been revised too. The complete English version of the monographic study is prepared.

Na VIII. kolokviu Orientalia Antikva Nova v Plzni v roce 2008 pronesl autor tohoto článku na téma kelčského nálezu již jiný přispěvek s názvem Metodologické problémy starších nálezů orientálních mincí v Českých zemích: Kelčský případ, in: Pecha, Lukáš, ed., Orientalia Antiqua Nova VIII. Sborník z vědeckého kolokvia, pořádaného v Plzni ve dnech 14. - 15. února 2008, s. 284 - 299, Plzeň 2008. Ten se obsahem věnoval revizi mincovní složky islámské provenience, která byla zajištěna již v době nálezu (1938).

Na přelomu minulého století byl v lokalitě Kelč detektorovou činností objeven další soubor mincí, jejich zlomků a zlomků stř́ibrných šperků, jehož souvislost s dřívějším kelčským depotem není v zhledem k absenci nálezových okolností jasně doložena (materiál byl nalezen v roce 2008 v pozůstalosti J. Háskové, pracovnice numismatického 
oddělení Národního muzea v Praze s pouhým označením „Kelč” a v současné době je uložen tamtéž). Na základě chronologicko-geografické a typologické analýzy materiálu Ize s velkou pravděpodobností konstatovat, že tento soubor byl součástí původního nálezu. V novém souboru je dochováno 27 celých tzv. křížových denárů a denárů otto-adeIheidského typu, 233 zlomků různých evropských denárư, 345 fragmentů islámských mincí, 6 neidentifikovatelných mincovních zlomků a 61 zlomků stříbrných šperků. Denárová ani šperková složka nebyly dosud zkoumány.

$\checkmark$ roce 2008 byly opět detektorovou činností nalezeny na téže lokalitě dva celé denáry (jeden rozlámán), jeden denárový zlomek a jeden islámský zlomek. Denárová složka dosud nebyla zkoumána.

Aktuálně je tedy z kelčského nálezu zachováno celkem (2008):

246 (stav před 2008) $+27+2($ stav k 2008) = 275 celých stř́ibrných evropských minci a $367+239+1=\underline{607}$ jejich zlomků,

$876+345+1=\underline{1222}$ zlomků islámských stříbrných mincí a jeden celý stríbrný dirham, $246+61=\underline{307}$ zlomků stříbrných šperků.

Kromě mincovní složky byly rovněž revidovány zachované textilní fragmen ty př́slušné nálezu. Jeden textilní fragment $z$ kelčského depotu byl zkoumán v polovině 90. let minulého století, kdy byl označen za konopný. Dle údajů očitého svědka vyzvednutí nálezu byl tento fragment součástí většího množství textilií, v nichž byl nález uložen. Pozdějším zkoumáním (2008) bylo zjištěno, že materiál byl zhotoven ze Inu. Autenticitu níže zkoumaných fragmentů nepř́mo potvrzuje i fakt, že byly s udáním téže provenience uloženy na dvou různých místech. V roce 2008 se revizí textilního materiálu uchovávaného v Olomouci ( 7 fragmentů z Krajského vlastivědného muzea v Olomouci) a v Hranicích (1 fragment z Městského muzea v Hranicích) zabývala M. Bravermanová ze Správy Pražského hradu.

Revidovaný stř́ibrný islámský zlomkový materiál is opravenými hodnotami jakož i skupina dirhamových fragmentů získaných v roce 2008, svým hmotnostním rozložením podporují tezi, že zlomky svou hmotností nekopíruji žádné kategorie odpovídající poměrným dílưm stříbrného nominálu (dirhamu) a fungovaly jako vážený kov.

Nové (2008) historické vymezení mincovního a nemincovního materiálu je následující: (+ značí materiál získaný detektorovou činností k roku 2008)

AD $98-117$ Řím

AD 969 - 976 Byzanc

(1 zlomek denáru) $(4$ stř́ibrné zlomky)

AD $929-1002$ Čechy

AD 997 - 1038 Uhry (16 denárů a jejich zlomků) $+X$ (1 denár)

AD 901-1016 Západní Evropa - Lotrinsko, Porýní, Frísko, Sasko, Franky, Švábsko, Bavory, Provence, Lombardie, Anglie
AD 10. století - tzv. otto-adelheidské a křížové denáry (342 denárů a jejich zlomků) + X AD 717 - 997 Islámské stř́ibro (1 dirham a $876+346$ zlomkن) AD 10. století Šperkové stříbro

$(246+61$ kusư)

Celek je datován do první dekády 11. století.

Z 346 fragmentů islámských mincí získaných v roce 2008 se jich podařilo do širších typologických kategorií (dynastie) zařadit 281, z nichž pak 105 se dostalo zpřesnění $v$ dalšich chronologicko-geografických aspektech (panovník, mincovna, ražebn ročník, citovaný chalífa, atd.).

Islámské zlomky z Kelče byly v novém třídění rozděleny do následujicích širších typologických kategorií (+ znamená materiál získaný k roku 2008): (A) zlomky sásánovských či arabo-sásánovských mincí (+ 1 kus), B) zlomky umajjovských mincí (1 kus), (C) zlomky 'abbásovských či sámánovských mincí (116 kusů + 45 kusů), (D) zlomky 'abbásovských mincí (51 kusů a 1 celá mince +10 kusů), E) zlomky sámánovských minci (224 kusů + 198 kusů), ( F) zlomky bújovských mincí (45 kusů + 19 kusů), (G) zlomky hamdánovských mincí (+ 1 kus), (H) zlomky ghaznovských mincí (1 kus + 1 kus), (I) zlomky nápodob sámánovských typů z produkce povolžských Bulghárů (7 kusů +5 kusů) (J) zlomky neislámských mincí (3 kusy). Při bližším srovnávacím určení a zjištění konkrétních údajů (panovník, mincovna, ročník, chalífa a jiné zpřesňující údaje + znamená materiál získaný k roku 2008) byly stanoveny tyto chronologicko-geografické celky: (A) zlomky sásánovských či arabo-sásánovských mincí (+ 1 kus), (B) zlomky umajjovských mincí (1 kus), (C) zlomky 'abbásovských či sámánovských mincí ( 7 kusů + 45 kusů) (D) zlomky 'abbásovských mincí (14 kusů a 1 celá mince +10 kusů), (E) zlomky sámánov ských mincí (146 kusů + 198 kusů), (F) zlomky bújovských mincí (17 kusů + 19 kusů) (G) zlomky hamdánovských mincí (+ 1 kus), (H) zlomky ghaznovských mincí (1 kus + 1 kus), (I) zlomky nápodob sámánovských typů z produkce povolžských Bulghárů ( 7 kusů + 5 kusů). Oproti pưvodním určením došlo u položek evidovaným do roku 2008 k posunu v rozvrstvení zaznamenaných mincoven a k tomu se připojily mincovny další z nově získaného souboru. Jediný, dřive nerozpoznaný, umajjovský zlomek byl ražen v mincovně Sábúr (Fárs), jejiž aktivity se pro tento prípad dají specifikovat intervalem AH 79-84, 90 - 98/ AD 698 - 703, 709 - 717. Jde tedy o nejstarší datovatelný zlomek islámského celku. Nejpočetnější mincovnou sámánovské části je Samarqand (Transoxanie), reprezentovaný 44 kusy. Dalši sámánovské transoxanské mincovny zastupuje 20 kusy aš-Šás (= Taškent) a čtyřmi kusy Buchárá. Další čtyři sámánovské zlomky byly raženy v Balchu (Churásán), dva v Nísábúru (Churásán) a jeden v mincovně al-Muhammadíja (Džibál). Mince pro dva 'abbásovské zlomky byly raženy v al-Ahwázu (Chúzistán) a dva v Samarqandu (Transoxanie). Madínat as-Salám (=Baghdád, 'Iráq) je u 'Abbásovců zastoupen třemi zlomky a al-Muhammadíja (Džibál) zlomkem jedním a jednou celou mincí. Na bújovských zlomcích byla s jistotou zjištěna pouze v jednom případě mincovna al-Basra ('Iráq), 
ale dle určených panovníků a rozsahu jejich dobové dominace Ize u několika kusů spekulovat o mincovnách v provinciích Fárs (Kázirún) a Džibál (ar-Rajj, Isbahán) či v provinciích Kirmán a 'Iráq. U ghaznovských zlomků nebylo možno mincovnu identifikovat, avšak $z$ historických souvislostí počátků této dynastie a vzhledem k nominálu (tlustší zlehčeny dirham, později zvaný džitál, okolo $3 \mathrm{~g}$ ) Ize usuzovat na některou z afghánských mincoven (Farwán, Bámján). Sumární údaje vykazují značnou rozptýlenost a vzájemnou velkou vzdálenost v geografickém rozložení jednotlivých islámských mincoven zastoupených v kelčském nálezu.

Zlomek okraje stříbrné mince s motivem hvězdy v půlměsíci pochází z min ce sásánovského či arabo-sásánovského typu (cca AD 579 - 713). Z hlediska chronologického a dynastického se lze $v$ prípadě umajjovského zlomku pouze teoreticky dohadovat o chalífovi 'Abd al-Malikovi (AH 65 - 86/ AD 685 - 7 05), al-Walídovi I. (AH 86 - 96/ AD 705 - 715) či Sulajmánovi (AH 96 - 99/ AD 715 - 717).

'Abbásovské zlomky reprezentují chalífy al-Mahdího (AH 158 - 169/ AD 775 - 785, ar-Rašída (AH 170 - 193/ AD 786 - 809, al-Mu'tamida (AH 256 - 279/ AD 870 - 892), al-Muqtadira (AH 295 - 320/ AD 908 - 932) a al-Muttaqího (AH 329 - 333/ AD 940 - 944). Jediná celá islámská mince souboru spolu se dvěma dalšími zlomky přináležejí chalífovi al-Ma'múnovi (AH 198 -218/ AD 813 - 833).

Sámánovci jsou v nálezu z Kelče zastoupeni následující panovníci: Ismá íl b. Ahmad (AH 279 - 295/ AD 892 - 907), Ahmad b. Ismá' íl (AH 295 - 301/ AD 907 - 913), Nasr ll. b. Ahmad (AH 301 - 331/ AD 913 - 942), Núh I. b. Nasr (AH 331 - 343/ AD 942 - 954), 'Abd al-Malik b. Núh (AH 343 -350/ AD 954-961), Mansúr l. b. Núh (AH 350 -366/ AD 961 -976) a Núh Il. b. Mansúr (AH 366 - 387/ AD 976 - 997). Z legitimizačních důvodů se na zlomcích jejich mincí objevuji tito 'abbásovští chalífové: al-Mu'tadid bi'lláh (AH 279 - 289/ AD 892 - 902), al-Muqtadir bi'lláh (AH 295 - 320/ AD 907 - 932), al-Oáhir bi'lláh (AH 320 - 322/ AD 932 -934), ar-Rádí bi'lláh (AH 322 -329/AD 934-940), al-Muttaqí bi'lláh (AH 329 - 333/ AD 940 - 944), al-Mustakfí bi'lláh (AH 333 - 334/ AD 944 - 946), al-Mutí li'lláh (AH 334 - 363/ AD 946 - 974), at-Tái' li'lláh (AH 363 - 381/ AD 974 - 991). Krom toho se ještě na jednom pozdním sámánovském zlomku objevuje bezejmenný guvernér ghaznovské dynastie s titulem Husám ad-Dawla.

Bújovce v souboru predstavuje Ahmad b. Búja (AH 324/334 - 338/356/ AD 936/946 - 949/966), Rukn ad-Dawla (AH 320 - 366/ AD 932 - 976), Mu'izz ad-Dawla (AH 320 - 356/ AD 932 - 967), 'Imád ad-Dawla (AH 320 - 338/ AD 932 - 949), 'Adud ad-Daw-la (AH 338 - 372/ AD 949 - 983), Mu'ajjad ad-Dawla (AH 360 - 373/ AD 970 - 984), Šaraf ad-Dawla (AH 372 - 379/ AD 982 - 989) a Fachr ad-Dawla (AH 366 - 387/ AD 976 - 997). Ze stejných důvodů jako u předchozí dynastie se na bújovských zlomcích z kelčského nálezu objevuji jména těchto 'abbásovských chalifư: al-Muti' li'lláh (AH 334 - 363/ AD 946 -974) a at-Tái' li'lláh (AH 363 - 381/ AD 974-991).

Zlomek hamdánovský spadá do společné vlády panovníků Násir ad-Dawla a Sajf ad-Dawla (AH 330 - 356/ AD 942 - 967, respektive AH 330 - 332/ AD 942 - 943).
Jméno 'abbásovského chalify at-Tái' li'lláh (AH 363 - 381/ AD 974 - 991) na jednom z ghaznovských zlomků neprímo ukazuje na vydavatele mince - Sebuktegina (AH 366 - 387| AD 976 - 997), jehož jméno v reversní legendě nezachovalo.

Nejstarším elementem je tedy zlomek sásánovského či arabo-sásánovského typu (cca AD 579 - 713). Mezi mincemi čistě epigrafického typu je nejstarším fragment umajjovský (circa AD 698 - 717) a nejmladšími pak zlomky bújovské a ghaznovské (circa AD 976 - 997). Časový interval s největší četností určených islámských zlomků v kelčském nálezu je vymezen lety zhruba AD 910 a AD 980.

Existence nového materiálu evidovanému $\mathrm{k}$ roku 2008 způsobila potřebu revize celkového objemu v následujících kategoriích: metrologie zlomků, chronologickogeografická distribuce zlomků, zlomky nápodob islámských mincí, význam zlomků a technologie jejich dělení, archeologicko-numismatický kontext kelčského smíšeného nálezu a interpretace nových závěrů.

Revize materiálu v současné době k dispozici přinesla následující závěry (výrazné změny výsledků v souvislosti s novým materiálem tučně):

- smišený nález v jižním segmentu odersko-viselské obchodní oblasti uplatňující praxi váženého kovu,

- vrchol poptávky po islámském stříbru před započetím vlastního mincování ve středoevropském prostoru (bernost islámských mincís garantovanou kontrolou ražby = sikka prítomnost cizích ražeb v oběžném systému malého objemu, nízká kvalita lokálních ražeb a neexistence drobné mistní mince),

- teritoriální a časová rozrůzněnost materiálu,

- relativně malé množství kovu v oběhu bez potřeby tavit, fragmentace probíhá v celém procesu pohybu oběživa,

- fenomén obíhání zlomků ze starých mincí v islámské složce = vysoká cena stř́bra malý objem cirkulace, značná teritoriální i dynastická rozrůzněnost nejmladších zlomku்,

- sámánovské mince rozhodující islámskou složkou nálezu ze zenitu př́livu stříbra, v ukončené a nepokračující podobě,

- neúspěšná snaha středoasijských obchodníků nahradit propad dovozu stříbra mincemi nových dynastií (Bújovci, Hamdánovci, Ghaznovci), raritní exempláře.

Literatura $\mathrm{k}$ tématu viz NOVÁK, Vlastimil (2008): Metodologické problémy staršich nálezů orientálních mincív Českých zemích: Kelčský prýipad, in: Pecha, Lukáš, ed., Orientalia Antiqua Nova VIII. Sborník z vĕ verze revizn'studjekelšského v́́ ná anglická monografická verze tohoto textu. 


\section{Ladislav Cabada Šárka Waisová}

\section{Postmoderní státy jako nositelé a zprostředkovatelé kantovské etiky v mezinárodních vztazích}

\section{Abstract}

The article examines the correlation and interconnectedness between the so-called Kantian ethics in international relations and specific group of states that bear, promote and intermediate Kantian norms in the international politics. The first part of the article presents the contemporary theoretical discussion on international ethics and its plurality, later the focus heads more on the basic characteristics and specifics of Kantian ethics in the comparison with other types of ethical approaches - and culture of anarchy (Alexander Wendt) - in international relations, the Hobbesian and the Lockean one. In the second part of the article we apply the theoretical concept of Kantian ethics on specific type of state in international system - the post-modern state - based on the definition of this type of state given by Georg Sorensen or Robert Cooper respectively. The analysis shows three categories of post-modern states developing and promoting the Kantian concepts in international relations - middle powers, civilian powers and good international citizens.

\section{Úvodem}

Po celé 20 . století se $v$ mezinárodní politice potýkáme mj. s otázkou, jak racionálně zdůvodnit etiku ve věku mocenské politiky a vědy. Po větši část 20 . století byly otázky (mezi)národní politiky do jisté míry uvolňovány z morálního hodnocení, což souviselo především s deklarovanou potřebou hájit národní zájmy a zajistit přežití státu. Od dru-

hé poloviny 20. století jsme však stále častěji vystaveni otázkám týkajícím se celého 
lidstva, jako jsou např. otázka použití zbraní hromadného ničení, otázka přístupu k potravinám, vodě, zdravotní péči, otázka spravedlivé dělby a distribuce (mezinárodních) veřejných statkư apod. (Přirozeně, mnohé z těchto otázek měly svou platnost rovněž před rokem 1945, nicméně nebyly globálně, resp. celoplanetárně nastolovány a reflektovány a neexistoval žádný rámec či aparát k jejich diskutování).

Žijeme také v době, kdy rozhodnutí a jednání jednotlivce může mít - zejména, ale nikoli pouze vzhledem $k$ rozvoji vojenských technologii - důsledky pro celé lidstvo. Taková situace vyžaduje etická měřitka, která platí pro všechny lidské jedince a kolektivity, tj. nejsou limitována parciálními (např. národními) politickými kulturami či politickými etikami. To nás staví do velmi zvláštní situace. Víme, že morální hodnoty a etické normy jsou rozmanité a liší se dle kulturního prostoru a doby, ale současně stav dnešního světa vyžaduje, abychom hledali a přijali taková etická měřítka, která budou platit všeobecně. Nehledáme již maximy jednání, nýbrž praktické zákony. ${ }^{1}$

V této souvislosti se vynořuje řada otázek, které bychom si měli položit. Jednou z klíčových otázek, a to zejména na základě zkušeností z 20. století, je otázka, zda mezinárodní politika může mít "etický rozměr", a pokud ano, jaké je pak místo morálky a etiky v mezinárodní politice? Autoři tohoto textu jsou hluboce přesvědčeni o tom, že oprostit mezinárodní politiku od mravnosti a etického rozměru je nemyslitelné a nesmysIné. $V$ době, kdy ve jménu humanity a spravedlivé války vedeme vojenské intervence, zřizujeme mezinárodní trestní tribunály a soudy a trestáme válečné zločiny a zločiny proti lidskosti - a v souvislosti s těmito aktivitami argumentujeme, že je potřeba konat věci dobré a nekonat věci špatné - není možné, abychom se v jakékoliv oblasti lidskè činnosti, a tudiž ani v mezinárodní politice, vzdali mravních a etických nárokن̊.

Domniváme se, že etický rozměr (tedy to, co je považováno za etické a kým to je považováno za etické) mezinárodní politiky vyrůstá z charakteru mezinárodní společnosti, zejména z její kultury a charakteru jejích členů. Cílem tohoto textu je provést normativní analýzu a určit, jaký etický rámec je dnes uplatňován v mezinárodní politice, tato otázka je přitom sama velmi obecná a jsme si vědomi toho, že je př́liš orientována na univerzální pojetí mezinárodní politiky. Uvědomujeme si rovněž to, že v mezinárod ních vztazích existuje pluralita normativně-etických přístupů a souhlasíme s těmi autory (Cooper, Sørensen, Šedivý ad.), kteří kjednotlivým etickým přístupưm v mezinárodni politice přiřazuji jako nositele odlišné typy států. Za žádoucí etiku mezinárodních vztahů, jež ve svých základech nese univerzální praktický zákon, považujeme kantovskou etiku a za její nositele pak tzv. postmoderní státy (oba kličové termíny následně v textu obšírně vysvětlíme). Etická pravidla, která prosazují postmoderní státy, jsme v souladu se soudobými teoretickými přistupy nazvali „kantovskou etikou”.
Naše hypotéza vychází z empirické zkušenosti, že v současném mezinárodním systému existuje určitá skupina států, které se svou kulturou a charakterem činů významně odlišuji od ostatních: chovaji se příkladně a správně (či své chování nejen s ohledem na tzv. národní zájem, ale s ohledem na prosazování a udržování univerzálních hodnot humanity a přirozených lidských práv považujíz za príkladné a správné) a pokoušejí se přesvědčit ostatní, aby se chovali podobným zpưsobem. Na začátku našeho textu tedy stručně představíme teoretické koncepty definující mezinárodní společnost a operacionalizující otázky kultury mezinárodní společnosti. Vysvětlíme rovněž, kde vidíme rozdíl mezi etikou a morálkou a jejich pozicía úlohou v mezinárodních vztazích. Následně se budeme zabývat již pouze konceptem kantovské etiky v mezinárodních vztazích, protože pouze etika mezinárodni společnosti vyrůstající z kantovských principů je dle naše ho názoru skutečně provázána s otázkou prosazování univerzálních etických principú $\checkmark$ mezinárodní politice. Ve druhé části textu pak budeme hledat aktéry mezinárodní politiky, kteří se dle našeho názoru chovaji v souladu s etickými principy označovanými jako kantovská etika. Představíme tedy koncept postmoderního státu v kontrastu k jiným typům státnosti v soudobém mezinárodním systému a ukážeme některé praktické projevy kantovských principů v politice těchto států včetně možné vnitřní kategorizace mezi různými typy postmoderních států jako nositelů kantovské etiky v mezinárodních vztazích.

Dodejme, že naše analýza bude založena na hledání konkrétních projevů charakterizujicích postmoderní státy jako nositele specifických etických přistupů v mezinárodní politice, tj. že budeme vycházet z empiricko-analytických pozic. Na druhé straně se nemůžeme vyhnout některým normativním soudům a dokonce axiomům, s nimiž budeme explicitně či implicitně pracovat. Naše pojetí státu, státnosti a mezinárodního systému logicky vychází z toho, co může být označeno jako "západní tradice”. V tomto ohledu i pojmy jako „správný” či „příkladný” nutně musejí vycházet z takového myšlenkového odkazu.

\section{Mezinárodni etika, kantovská etika a kantovská dimenze politiky}

Morální hodnoty jsou esenciálním prvkem mezinárodních vztahů a mezinárodní etika je důležitým prvkem globální politiky. Období, kdy řada badatelů tvrdila, že pro mezinárodní vztahy jsou morální hodnoty a etika marginálními tématy, protože mezinárodním vztahům vládnou jiné mravní zásady než je tomu v prípadě domácí politiky, již zřejmě minula, byṫ ještě nedávno někteří autoři (výrazně v souladu s organickým pojetím státu jak jej nacházíme např. u Platóna či Hegela) prohlašovali, že mezinárodní politika je amorální sférou - tedy nikoliv nemorální (srovnej např. Kennan 1985)² -, protože stát

2) Kennan tvrdí, že „stát je hráč, nikoliv nadřizená autorita. Stát je primárně povinován zájmu národní společnosti, kterou reprezentuje, nikoliv nějakým morálním podnětưm které vycházejíz individuálních přáni členů společnosti. ... Zájmem národní společnosti, 

jako dokonalý organismus se, dokud je dostatečně silný, v žádném ze svých činů nikdy nemưže mýlit a v zájmu zachování vlastní moci a existence má stát právo činit násilí, a to jak na svých občanech, tak na jiných státech. $V$ době, kdy podnikáme humanitární intervence a zpochybňujeme absolutní platnost suverenity zdůrazňováním odpovědnost chránit lidské jedince a kolektivity, je zrejejé, že morální hodnoty a etika mají v mezinárodních vztazích významné místo.

Domniváme se, že aplikace morálních zásad na politiku má sice své meze, avšak nelze ji v žádném prípadě odmítnout ani vyloučit. Parafrázujíce Kennana tedy zdůrazňujeme, že činy státu a společnosti mají morální kvalitu, jsou subjektem posuzování a mohou být označeny za „špatné" nebo "dobré". Protože jsme přijali myšlenku, že mezi politikou a etikou existuje "vztah" - tedy že politika je sférou, v níž lze aplikovat morální či etické principy -, musíme uvažovat o tom, co je to morálka a etika a jaký je vztah mezi etikou a političnem.

\section{Morálka a etika v mezinárodních vztazích}

Slovo „morálka” vychází z latinského mores, což znamená zvyk, obyčej a zpưsob života. Tento termín popisuje, co je dobré, správné a vhodné, resp. náležité. Termín etika je odvozen od řeckého ethos, což znamená zvyk nebo běžnou praxi. Protože jsou si oba pojmy významově blízké, velmi často jsou použivány jako synonyma a zaměňovány. Z pohledu normativní analýzy je však oba pojmy nutné rozlišovat. Morálka odkazuje k hodnotám a myšlenkám o tom, co je správné a špatné, dobré a zlé, spravedlivé a nespravedlivé. Morálka obsahuje principy nebo pravidla chování, která vládnou nebo by měly vládnout společnosti. Etika odkazuje $k$ analýze, ospravedlnění a kritické reflexi morálky. Označuje systematické úsilí porozumět morálním konceptům a ospravedlnit morální principy. Morální normy si nárokují zejména univerzální platnost, tj. jsou závazné pro všechny lidi, a nestrannost, tj. jsou definovány bez ohledu na to, abychom věděli, kdo z nich profituje. Etika v sobě zahrnuje možnost výběru toho, co je správné a dobré a umožňuje zdržet se toho, co je špatné a zlé. Pưsobí jako prưvodce jednáním pro jedince i skupiny. $Z$ etické perspektivy je dobro konáno prostřednictvím aplikace správných morálních norem na soukromou či veřejnou sféru (Amstutz 2008: 8 - 9; Pojman 1990: 2). Etika je na morálce založený rozhodovací proces, v němž dochází kidentifikaci, interpretaci a aplikaci morálních principů na určitá témata a problémy (Amstutz 2008: 27).

který vláda musí prǐijmout za svưj, je zejména zajištění vojenské bezpečnosti, integrity politického života státu a blahobytu obyvatel. Tyto potřeby nemaji žádnou morální kva litu. Jsou to nevyhnutelné základní životní potřeby a proto nemohou být klasifikovány jako 'dobré' nebo 'špatné'" (Kennan 1985: 206).
Aplikace morálních norem na veřejnou sféru je velmi obtížná, nebot v této sféře, resp. v konkrétních politických tématech, se překrývají různé morální hodnoty což v praxi znamená, že tvưrci rozhodnutí se musejí rozhodovat mezi jednotlivými alternativami. Etická obhajoba určitých témat v mezinárodních vztazích pak zahrnuje identifikaci, objasnění a aplikaci relevantních morálních norem na chování a postoje států v zahraniční politice (Amstutz 2008: 9). Morálka a etika tedy určitým způsobem omezují či limitují moc státu, podobně na stát působí i právo. Z vyjmenovaných kategorií je to právě etika, která je nutností rozkazovat a trestat zatížena nejméně, nebot'v sobě zahrnuje možnost výběru „správných” věcí; morálka ani právo naopak možnost výběru neposkytují.

\section{Mezinárodní etika}

Chceme-li se zabývat otázkou, zda v soudobém mezinárodním systému lze prosazovat univerzální etické principy - potažmo zda v mezinárodních vztazích můžeme pozorovat nositele či zprostředkovatele kantovské etiky - pak je nutné vyjasnit, zda existuje singulárni či holistická mezinárodní etika. Důležité je rovněž vyjasnit vztah mezi mezinárodní etikou a kantovskou etikou.

Autoři, kteři se zabývají otázkami mezinárodní etiky, se shodují v názoru, že společnost států, která sdílí určitou kulturu, produkuje určitou etiku. Otázka existence mezinárodní etiky tak souvisí s otázkou, zda existuje společnost států. Mnozí autoř (např. Carr 1939; Morgenthau 1993; Vincent 1978 nebo Dwivedi 1987) se domnivají, že před mnoha staletími existoval „jeden" souhrn mravních zásad platný pro jedince i státy - rozuměj politické autority - a to díky existenci společnosti panovníků, kteří byli rodově spřizněni a provázáni majetkově i kulturně, resp. společensky. V souvislosti s vývojem moderního státu však došlo k odosobnění politické autority, nebot' loajalita občanů se přenesla z osoby panovníka na státnost a stát. To způsobilo „rozdvojeni” etiky, přičemž jedna zưstala vlastní jedincưm a druhá se začala vytvářet jako etika státu a jeho politických představitelů a směřovala jak do domácí politiky, tak do mezinárodního prostředí (Carr 1939: 147 - 148).

Tento okamžik rozdvojení etiky je zásadním zlomem problematizujicím dalši existenci mezinárodní etiky. Zatímco personifikace státu s panovníkem a provázanost evropských panovnických rodin zajištovaly to, že všechny státy na evropském teritoriu sdílely stejný souhrn mravních zásad, v okamžiku rozvázání pout mezi panovnickým rodem a státem a s následným odosobněním politiky se začala etika jednotlivých států přizpưsobovat chování konkrétního státu a kultuře státotvorné společnosti.

$\checkmark$ relativně krátkém období (mezi 16. a 19. stoletím) vznikla propast mezi etikou jedince a etikou státu a mezi mravními zásadami jednotlivých států. Etablováni moderního státu, jež je obecně vnímáno jako zásadní progresivní bod ve vývoji lidstva, přispělo nejen k tomu, že stát absolutně ovládl jedince (dosáhl monopolu legitimního násil nad svými obyvateli), ale také rozpadu univerzální (západní) mezinárodní etiky. Souhrn 
na základě rozdílného vnímání a přijímání funkce organizovaného násilí a rolí, které v systému a subsystémech prevládají (Wendt 1999: 247). Hobbesovská, lockeovská a kantovská kultura jsou chápány jako ideáltypy a proto nejsme schopni plně rozlišit tř skupiny zemí v mezinárodním systému, které by tyto etiky plně reprezentovaly. Nehledě na to se řada autorů pokouši definovat takové skupiny států a ukázat, že odlišné typy jejich etik vedou v mezinárodním systému k odlišnému chování.

Hobbesovská kultura je ztotožňována s myšlenkou T. Hobbese, že člověk se v přirozeném stavu nachází v situaci permanentní války všech proti všem. $V$ hobbesovské kultuře mezinárodních vztahư je násilí běžným a legitimním nástrojem zahraničn politiky, přičemž jednotliví aktéri se vnímají jako nepřátelé rídící se logikou „zabij nebo budeš zabit". Podle Wendta (1999: 247 - 254) hobbesovská kultura předpokládá, že státy žiji ve stavu permanentního neprátelství (jsou si navzájem nepřáteli), neuznávaji ostatní státy a často využívaji válku jako zahraničně-politický nástroj. Jediným cílem státu v mezinárodním systému je přežít. V současnosti je takový typ vztahů mezi státy v mezinárodním systému výjimečnýs, protože hobbesovská kultura byla povětšinou nahrazena lockeovskou kulturou.

Nejvýznamnějši charakteristikou lockeovské kultury je uznání konceptu suverenity v mezinárodním systému. Uznání suverenity jako základního principu limituje užití násilí v mezinárodních/mezistátních vztazích. Státy již nežijí v nepřátelství, nýbrž v rivalitě - soutěží mezi sebou. Většinou mezi sebou neválčí, protože to pro ně neni výhodné (ve válkách může stát ztratit bohatství a prosperitu nebo stabilitu). Podle Jiř́iho Šedivého (2002: 14) státy v rámci lockeovské etiky svou identitu zakládají na vymezen vưči rivalovi na principu "My" a „Oni”.

Třetí typ kultury bývá označován jako kantovská; toto označení vycház Z Kantova filozofického eseje $K$ věčnému míru. Kantovská kultura je založena na principu, že státy jsou si navzájem přáteli, spolupracují, nenásilně řeší své vzájemné konflikty a neakceptuji válku jako nástroj zahraniční politiky (Wendt 1999: 246 - 312). Právě kantovskou kulturu anarchie, kterou charakterizuje role „prítele”, sdílejí podle autorů věnujících se tomuto tématu, postmoderní státy (viz níže). Role přitele je založena na vzájemném očekávání, že 1 . spory budou vyřešeny bez násilí a 2. pokud bezpečnost jednoho je ohrožena, ostatní jsou zavázáni mu pomoci (Wendt 1999). V praxi se ti, kteř uznávají kantovskou kulturu anarchie, stávají členy pluralitního bezpečnostního společenství a systému kolektivní bezpečnosti.

5) „Pluralistická bezpečnostni společenství představuji transnacionální region, tvořenỳ existujicími suverénními státy, jejichž obyvatelstvo očekává, že změny ve vzájemných vztazích budou probihat mírovou a nenásilnou cestou a že se ostatní nepripravují k užiti organizovaného násili" (Adler a Barnett 2000: 30). 
Wendt a další autoři tedy uvažují o soudobém mezinárodním systému jako o systému heterogenním, v němž mưžeme rozlišit různé typy kultur anarchie, resp. etik. Podle Císaře (2005: 218) Wendt v tomto směru následuje konstruktivistické projekty v mezinárodních vztazích, které předpokládají, že některé státy respektují lidská práva nikoli proto, že je to pro materiálně užitečné (lockeovská etika), ale protože v tyto hodnoty věrí (kantovská etika).

\section{Kantovská etika a kantinánstvi v mezinárodni politice}

Vycházíme-li z předpokladu či závěru, že jedna celoplanetární etika na makroúrovni neexistuje, je třeba, abychom vysvětlili, co máme na mysli, když hovoříme o kantovské etice. Důvodem, proč používáme termín „kantovská etika” a nikoliv zavedené termíny "etika presvědčeni" (Gesinnungsethik) a "etika zodpovědnosti” (Verantwortungsethik) je, že se jedná o etiku morálního kompromisu. Kantovská etika vychází z deontologického krídla osvícensko-liberální morálky, avšak svou podstatou neodpovídá zcela etice přesvědčení (srovnej např. Weber 1998: 246 - 296). Etika přesvědčení nařizuje takové jednání, které je v souladu s vyznávanými morálními principy, i když by důsledky takového jednání zničily vlastní fyzickou existenci jednajícího. V praktické politice si státy, a to ani postmoderní, nemohou cenit morálních principů nad vlastní existenci. Termín kantovská etika tedy naznačuje, že se jedná o etiku, která není totožná s Kantovou etikou, ale je jí blízká. Blízkost obou konceptů spočivá ve snaze najít a uplatňovat univerzáln etické přistupy. Zásadní odlišnost naopak tkví v poznání aktérů soudobého mezinárodního systému, že situace plurality kultur anarchie - a rovněž racionalita ochrany základního národního zájmu, tedy přežití státu - znemožňuje univerzální a zcela neomezenou aplikaci kantovských morálních principů. Jinak řečeno, státy prosazující kantovskou eti ku v mezinárodních vztazích na ni musejí rezignovat v interakcích s aktéry, kteří se řídi jinými - lockeovskými či dokonce hobbesovskými - principy mezinárodní politiky.

Kantovská etika klade velký dưraz na správné a dobré záměry aktérư, na universalitu (či tíhnutí k ní), což znamená, že morální normy jsou závazné pro všechny lidi, a vlastní hodnotu člověka. $V$ kantovské etice mají být morální závazky naplněny ne proto, že jsou prostředkem našich výhod, ale protože to morální čin vyžaduje. Ohled k druhým a morální zákon, jenž ho přikazuje, mají být cílem samy o sobě. Kantovská etika však není a nemůže být totožná s Kantovou deontologickou etikou přesvědčení. (Kantova) etika presvědčení nařizuje jednat tak, aby to bylo v souladu s vyznávanými morálními principy, at již důsledky jednání budou jakékoliv - včetně možnosti ztráty vlastní existence. Postmoderní státy nemohou zcela překonat své sobectví, nebot jemu vděčí za svou existenci. Kantovská etika tak počítá s morálním kompromisem. Současně kantovská etika překonává Kantovu na racionalitě založenou etiku, nebot připouští, že mohou existovat dalši hodnoty či bytosti (např. rozum nemající zviřata), které mají morální význam. Kantovská etika se neřídí Kantovým principem racionality. Pro kantiány skutečnost, že určitá bytost není nadána rozumem, neznamená, že své chováni vưči ní nebudou omezovat. I bytostem, které nejsou nadány rozumem, nesm být zpưsobováno zbytečné utrpení.

Rámce pro morálku jsou u nositelů kantovské etiky - postmoderních států - formovány v interakci mezi na jedné straně politickými elitami a vládami a na straně druhé mezi domácími i transnacionálními societálními aktéry. Oslabení hranice mezi domácím a zahraničním, demokratizace zahraničně politického procesu a větší míra účasti nestátních aktérů na tvorbě agendy umožnily, aby morální hodnoty světové společnosti byly zaneseny do zahraničně politického a mezinárodně politického diskurzu. Pro postmoderní státy již nadále neplatí existence dvou rámců pro morálku, nebot přijaly morální hodnoty světové společnosti. Postmoderní státy již neposkytují dobro jen $\checkmark$ rámci svých hranic, ale pokoušeji se je rozširíit i do dalších regionů, a to na základě představy o existenci globálního ekosystému a odpovědnosti vưči těm, kteřížijí za jejich hranicemi. Postmoderní státy akceptovaly myšlenku, že je potřeba současně klást dů raz na hodnotu individuálního člověka, na solidaritu lidstva a hodnotu lidské existence a vývoje. Postmoderní státy jednají jménem globální občanské společnosti (Vincent 1986: 124; Frost 2001: 33 - 53)

Kantovská etika na makroúrovni - alespoň částečně - opouští státocentrickou perspektivu, nebot přijímá morální principy, které uznává (globální) občanská společnost, a aplikuje je na všechny lidské jedince. Kantovská etika činí z postmoderních států „služebníky lidstva” (servants of humankind; Jackson 2004: 62). Kantiánství jde za systém států, nebot' odmítá, že by státní hranice demarkovaly morální povinnosti a závazky. Občané jednoho státu mají povinnost vưči ostatním lidským jedincưm, což znamená, že státy - jako aktéři zastupující své občany - mají exteritoriální povinnosti, a to nejen vưči ostatním státům, ale i vơči lidským jedincům (Penz 2001: 43). Stávající mezinárodní politika by měla být podle kantiánů nahrazena novým politickým věkem, který konečně ukončí období válek a krizových situací, jimiž byl svět dosud zamořen. Za kantiány lze považovat ty, kteří pracují pro vyšší hodnoty a konaji ve jménu vyšší vize, a kterí ze zásady odmítají zkorumpované pohodlí a zkažené nastavení klasické diplomacie. Spravedlnost mezi státy - o níž usiluje klasická diplomacie - není podle kantiánů opravdovou spravedlností, nebot’ diplomacie je špinavým handrkováním vládců a formou jejich konspirace proti společnostem, kterým vládnou. Skutečná spravedlnost je pochopitelná jen ve vztazích mezi jedinci. Podle kantinánư je tradiční diplomacie přežitkem nedemokratických dob, kdy vládcové rozhodovali o osudu lidu bez jeho kontroly (Barša a Císař 2008: 168). Politicky pragmatická a morálně kompromisní konvenční diplomacie musejí být nahrazeny opravdovou spravedlností (Wight podle Jackson 2004: 63; Barša a Císař: 2008). Kantiánství zahrnuje multilaterální jednáni prostřednictvím šírení mezinárodních organizací a konferencí a demokratizace zahraničně politického procesu.

Jak jsme opakovaně zmínili, autoři operujicí s pojmem kantovská etika se shoduji na tom, že existuji-li v soudobém mezinárodním systému specifičtí nositelé jejích hodnot, pak jsou to postmoderni státy. Podívejme se tedy na to, jak je tento typ státu 
Moderni státy jsou založeny na myšlence suverenity a přisně ochraňují svưj monopol na užití silly. Tuto silu neváhají užít ani vưči ostatním státům.

Třetí skupinu států préedstavují postmoderni státy. Podle R. Coopera (cit. dle v mezinárodním systému.

\section{Postmoderní státy jako nositelé kantovské etiky}

Politologové se většinou shodují v tom, že konec studené války byl významným milníkem ve vývoji mezinárodních vztahů a charakteru mezinárodního systému a že $s$ koncem studené války nastává kvalitativně nová éra mezinárodní politiky. Neshodují se však v tom, jaké vývojové tendence převládnou v mezinárodním systému, jakou perspektivou je nahližet, případně jak vysvětlovat proměny, k nimž v mezinárodním systému dochází. Jedním z přistupư, ke kterému se $v$ této stati príkláníme i my, je evolučni přístup uznávající, že dochází k vývoji a proměnám kultur a institucí, přičemž určité charakteristiky zưstávají, protože v konkrétním prostředí mají funkční výhody. Tento př́istup reprezentují např. práce Hedleyho Bulla (2002 [1977]), Johna G. Ruggieho (1993) Ronalda Ingleharta (1997), Georga Sørensena (2005 či 2006), Alexandra Wendta (1999) či Roberta Coopera (2000 či 2003). Všichni zmínění autoři zasazují stát do širšího historického rámce a domnivaji se, že společnost, mezinárodní společenství, stát a státnost jsou proměnlivé entity, které podléhají logice vývoje. Jednotlivé vývojové stupně státnosti a jednotlivé společnosti se vyznačuji odlišnou organizací politického a ekonomického života i odlišným hodnotovým a kulturním rámcem.

Otázku odlišných kultur a etik zmínění autoři spojuji právě se skutečností, že $\checkmark$ mezinárodním systému paralelně existují různé typy států. Sørensen či Cooper tak např. rozlišují tři odlišné (ideál)typy států v soudobém mezinárodním systému. Sørensen hovoří o postmoderních, moderních a postkoloniálních státech, Cooper nahrazuje termín postkoloniální svou vlastní kategiorií premoderního státu. Různé typy státu se vzájemně odlišuji na základě úrovně ekonomického rozvoje a modernizace, ale zejména se liší s ohledem na svá bezpečnostní dilemata a chování v mezinárodních vztazích. Různé vývojové stupně státu a státnosti se díky jinému typu sociálního uspořádání a odlišnému hodnotovému rámci projevuji mj. kvalitativně jinou zahraniční politikou, a to v oblasti nástrojů, cílů i procesu její tvorby. Změny stylu i obsahu zahranični politiky se pak projevuji v mezinárodním systému zejména snahou států chovat se "jinak".

Postkoloniální či premoderní státy můžeme označit jako jednotky, které jsou ekonomicky slabé - národní hospodářství bud'vưbec neexistuje nebo není schopno zajistit základní úroveň blahobytu. Podle J. Šedivého (2002: 12) monopol státu na násili u tohoto typu státu fakticky neexistuje; nejsme schopni rozlišit hranici mezi vnitřním pořádkem a vnější anarchií. Podle Sørensena (2005: 103) se postkoloniální státy vyznačuji strukturální heterogenitou - v systému koexistuji různé typy produkce včetně moderní průmyslové produkce, ale rovněž feudální či polofeudální struktury v zemědělství.

Moderní státy jsou založeny na moderním nacionalismu, jsou výrazem svého národa, reprezentuji národ a zajištujuji pro národ základní sociální hodnoty. Podle Sørensena (2005: 94) je u moderních států bezpečnost národa ztotožněna s bezpečností státu.
Šedivý 2002 : 12) byla v těchto státech setřena hranice mezi domácí a zahraniční politikou, aktéři vytvořili systém institucí, který zasahuje do jejich vnitřních záležitostí a suverenity a význam hranic klesá. Podle Sørensena (2005: 106 - 108) postmoderní státy rezignuji na soběstačnost, jejich ekonomiky jsou vzájemně propojené a závislé. Systém rozhodování je založen na víceúrovňovém vládnutí a „plurilateralismu”.

Posun některých západních společností a států od modernity $\mathrm{k}$ postmodernitě můžeme pozorovat od 70 . let 20. století. Podmínky, které tento vývoj umožnily, se však začaly v západních společnostech formovat již po druhé světové válce. Vývoj mnoha společností směrem k postmodernitě pak urychlil konec studené války, který otevřel prostor pro demokratizaci některých dosud demokratické kontrole se vymykajicích č ne zcela podřizených politik na čele s politikou bezpečnostní a zahraniční.

Mezi předpoklady postmodernizace patří zejména existence demokratických politických institucí a zajištěná materiální bezpečnost. „Postmoderní společnosti už nemusejí bojovat o holé přežití, usiluji spiše o maximalizaci subjektivního blahobytu” (Inglehart 1997: 14 a 35). V procesu postmodernizace dochází k posunu společnosti, kultury a institucí od materialistických hodnot zdůrazňujících ekonomickou a fyzickou bezpečnost $\mathrm{k}$ hodnotám postmaterialistickým zdůrazňujicím sebevyjádření a kvalitu života. Postmaterialisté nejsou ani anti-materialisté ani nematerialisté. „Pojem 'postmaterialismus' vyjadřuje sadu cílů, kterých má být dosaženo až poté, co lidé dosáhli materiální bezpečnosti, a jejich přijetí je umožněno, protože lidé dosáhli materiální bezpečnosti" (Inglehart 1997: 35; kurziva v originále).

Postmoderní společnosti se vzdaluji od standardizovaného funkcionalismu a nadšení pro vědu a ekonomický růst a berou daleko větší ohled na estetický a lidský prvek a na kvalitu života, život jako takový, jeho význam a hodnotu. $V$ postmoderních společnostech ekonomická racionalita určuje lidské chování daleko méně, důležitěǰš́mi se staly kulturní faktory. Přechod k postmodernitě se projevil i v transformaci institucionální struktury. Pro naši argumentaci je mimořádně dủležité, jak se přechod k postmodernitě projevuje právě v institucionální rovině a politické sfére. Zatímco moderní společnost se vyznačovala hierarchickým a byrokratickým uspořádáním, postmodern společnosti opouštějí byrokratický stát, disciplinované oligarchické politické strany, masovou produkci a tradiční odborové organizace (Inglehart 1997: 12 - 28). V politické oblasti přechod k postmoderním hodnotám oslabil respekt vưči autoritám a loajalitu vưči hierarchickým politickým stranám a zvýšil zájem o politickou účast a sebevyjádření. Postmoderní společnosti už nechtěji jen volit, chtějí ovlivňovat politické instituce a rozhodovací proces daleko aktivněji (Inglehart 1997: 43).

Vznik postmoderní státnosti však neumožnila pouze transformace na mikroúrovni, tj. přechod společností od modernity k postmodernitě. Transformace státnost 
vyžadovala také určité proměny na makroúrovni, tj. na úrovni mezinárodního systému. Postmoderní státnost se mohla rozvinout až v souvislosti s oslabením vestfálské ho paradigmatu.

Přechod některých společností od modernity $\mathrm{k}$ postmodernitě a transformace státnosti umožnily, aby v mezinárodním systému separátně a lokálně docházelo k tomu, že se vyvinul nový a specifický subsystém. Tento nový subsystém je tvořen státy, které se chovají radikálně odlišně v porovnání se svou minulostí i v porovnáni se současným chováním jiných typů států v mezinárodním systému, resp. dalších subsystémech. $\vee$ současné době to znamená především to, že normy jako suverenita, neintervence či nezávislost a principy jako rovnováha moci a národní zájem definovaný jako posilování vojenské a ekonomické moci ztratily pro tuto skupinu států svoji absolutní platnost (Cooper 2002: 7).

Podle Roberta Coopera je jedním z nových (postmoderních) subsystémů evropský prostor. Na Cooperovu argumentaci a charakteristiku postmoderních států se podíváme podrobněji, nebot' - byt’ se vztahuje $k$ Evropě či původně k západní Evropě se domniváme, že může být zobecněna. Musíme předeslat, že Cooper uvažuje o postmodernich státech, nikoliv o postmoderních společnostech a za začátek éry postmoderních států považuje konec studené války. To však neznamená, že by se domníval, že postmodernita je produktem konce studené války; jednotlivé západní společnosti se ocitly na postmoderní trajektorii daleko dřive než v roce 1990, avšak - a to je důvod proč Cooper éru postmoderních států zahajuje až po studené válce - navenek, tedy v zahraniční a mezinárodní politice se postmodernita začíná projevovat až v okamžiku, kdy konec studené války umožní ukončit desetiletí trvající politiku prežití. Parafrázujeme-li Ronalda Ingleharta, až poté, co státy a jejich společnosti dosáhly materiální a fyzické bezpečnosti a nemusejí bojovat o holé přežití, mohly usilovat o maximalizaci subjektivního blahobytu (Inglehart 1997: 35)

Přechod evropských států směrem k postmodernitě umožnily vedle již zmíněných faktorů (proměna společnosti a konec studené války) zejména NATO, Smlouva o konvenčních ozbrojených silách v Evropě a Smlouva o otevřeném nebi (obě garantované OBSE), Konvence o chemických zbraních a evropský integrační proces (srovnej např. Cooper 2000: 20 - 21 a 24 - 28; Sørensen 2005 či Ruggie 1993). NATO, obě zmíněné smlouvy a Konvence o chemických zbraních i pokračujicí evropský integrační proces otevřely v Evropě prostor k transformaci pojetí bezpečnosti. Smlouva o konvenčních zbraních v Evropě stanovila horní limity velikosti armád a jejich výzbroje a verifikační opatření obsažená ve Smlouvě o konvenčních zbraních v Evropě a Smlouvě o otevřeném nebi mj. umožňuji státům-signatářům kontrolní přelety nad územím ostatních státůsignatářů a zavazují je sdělovat konkrétní vojenské informace (přesun armád, vojenská cvičení atd.) ostatním členským státưm. Obě smlouvy se staly významným nástrojem budování důvěry, přičemž - jak je patrné - opatření obsažená v obou smlouvách nekonvenují s tradičním absolutním pojetím suverenity.
Podobný dopad jako obě smlouvy má působení Severoatlantické aliance. Členové Aliance maji detailní přehled o ozbrojených silách svých partnerů a v rámc NATO integrované velení ozbrojených sil. Co se týká transformačního vlivu evropského integračního procesu, jedná se zejména o institucionalizaci spolupráce $v$ oblasti bezpečnostních a obranných politik a o prosazení principu mnohoúrovňového vládnutí. Mnohoúrovňové vládnutí zahrnuje přesun tvorby rozhodnutí a pravomocí a jejich výkonu, a to směrem nahoru i dolů od národních vlád. Tato transformace společně s technologickým pokrokem (rozvoj komunikačních prostředků, rychlost přenosu informací) demokratizací zahraniční politiky umožnila jednotlivcům i občanské společnosti daleko více ovlivňovat rozhodování politických elit a participovat na výkonu těchto rozhodnutí, a to i v zahraničně-politických záležitostech.

NATO, EU i obě smlouvy garantované OBSE přispěly k tomu, že mezi evropskými státy přestal platit princip rovnováhy moci, byla stržena bariéra mezi domácím a zahraničním ${ }^{6}$, bylo vytvořeno víceúrovňové vládnutí založené na nadnárodních, státních a substátních institucích, klesl význam fyzických hranic a exkluzivity teritoriality jako takové’, došlo k vyloučení použití síly jako nástroje řešení konfliktů a následné kodifikaci pravidel chování a bezpečnost je nadále založena na transparentnosti, vzájemné otevřenosti, vzájemné závislosti a vzájemné zranitelnosti. Zdrojem občanských práv se staly nadnárodní a mezistátní instituce a kolektivní identita je spojena s nadstátní i substátní úrovní (Cooper 2000: 22; Ruggie 1993; Sørensen 2005: 148).

Postmoderní státy ustupují od absolutního pojetí suverenity a nezávislosti a pod vlivem postmaterialistických hodnot a postmoderní kultury se přiklánějí k tomu že maji odpovědnost nejen vưči svým občanům, nýbrž vưči všem lidem (jako jednotlivcům, skupinám jednotlivců i lidstvu jako celku) ${ }^{8}$, přičemž nejde pouze o zajištění fyzické existence, ale o celkovou kvalitu života. Pro postmoderní státy prestává platit tvrzení, že „obhajoba neintervence si volí rámec společností států, kdežto zdůvodňování humanitární intervence, prosazující lidská práva, jež jsou státy povinny dodržovat, vycházej z rámce jedince" (Vincent podle Neumann 2005: 59).

Vysvětlení překonání dichotomie morálních rámců globální občanské společnosti na jedné straně a společnosti států na straně druhé nabízí Mervyn Frost, když

6) Ruggie označuje prostor Evropských společenství, kde došlo ke stržení hranice mezi domácím a zahraničním, jako "multiperspectival polity”, tedy "multiperspektivní politickou obec" (Ruggie 1993: 172).

7) Ruggie tento stav označuje jako „unbundling of territoriality , tedy „rozvazování teritoriality" (Ruggie 1993).

8) Tento pristup v zahraniční politice označil Cranford Pratt jako "human internationalism”. Pratt pripisuje, human internationalism" zahranični politice střednich mocnosti. Vice srovnej např. v (Pratt, 1994). 
odpovídá na otázku, zda být členem občanské společnosti je slučitelné se statutem občana ve společnosti demokratických států. Frost se domnívá, že mezi společností států a občanskou společností nenacházíme vztah rivality ${ }^{9}$ a tudiž, že princip nezasahování do vnitřní politiky států se nemusí vylučovat s humanitární intervencí (Frost 2001: 48 - 49) Podle Frosta je "humanitární intervenci potřeba chápat nikoliv jako narušení principu neintervence, který je zakořeněn mezi suverénními státy, ale jako akt směřujićí k potvrzení principu nezasahování do sféry občanské společnosti, který chrání svobodu jednotlivce ${ }^{10}$. Uznání této normy nepodkopává princip neintervence platný v systému suverénních demokratických států, ale je předpokladem pro vznik praxe demokratických a demokratizujicích se států s jejich vlastním principem neintervence zakazujicí intervenci do jejich vnitřních záležitostí. Jen lidé, jejichž základní práva jsou uznána (tj. jen jedinci, kteři jsou ustanoveni lidmi), mohou se společně uznat za občany v rámci demokratických států a tyto státy pak budou mít právo na uznání principu neintervence do jejich vnitřních záležitosti" (Frost 2001: 51).

Postmoderní státy chápou humanitární intervenci v kontextu globální občanské společnosti: konají jménem společnosti, která je základem, na němž je vystavěna jejich legitimita. Národní zájem postmoderního státu neexistuje nezávisle na právech jedinců. Postmoderní společnosti nepopírají význam a roli státu a chtějí, stejně jako jiné typy států, zajistit svou existenci, kterou chrání, nikoliv však na úkor ostatních a tedy bez expanzivních nároků. Vedle vlastní existence je součástí národních zájmů postmoderních států zajištěni přiměřené bezpečnosti a blahobytu, či obecněji řečeno kvality života všech dalších lidí. Postmoderni étos zahrnuje jak ochranu vlastní existence, tak ochranu ostatních lidských bytostí.

\section{Postmoderní státy jako nositelé a zprostředkovatelé norem}

Jak jsme nastínili výše, v souladu s rozlišitelnou pluralitou typů států a na ně se vážících etických principů v mezinárodních vztazích považujeme postmoderní státy za nositele etických principư či norem, jež jsou souhrnně označovány jako kantovská etiky. Normy nicméně nevznikaji samy o sobě, ale jsou aktivně vytvářeny konkrétními aktéry, kteř mají jasné představy o vhodném, resp. nevhodném chování a jednání v konkrétním

9) „Nebot’občanstvíje bezcenné, pokud občané nejsou konstituováni současnějako lidšti jedinci, jako držitelé základni práv v rámci globálni praxe občanské společnosti" (Frost 2001: 49).

10) Ve sféře občanské společnosti vytvárí princip nezasahovánísoukromýa depolitizovaný prostor, vjehož rámci požívajíjedinci autonomii. Podobně je tomu i ve společnosti států. Vobčanské společnosti princip neintervence chráníprostor pro individuálníaktéry, ve společnosti států chrání prostor pro kolektivniho aktéra, stát. Státje kolektivníaktér vytvářený občany a vjehož rámci je vytvářeno občanství(Frost 2001: 46nn). společenství (Finnemore a Sikkink 1998: 896). Státy a další aktéŕi - včetně postmoderního typu státu - tak nevystupují pouze jako nositelé, ale také jako zprostředkovatelé norem v mezinárodním společenství. Za "nositele a zprostředkovatele norem” jsou označováni aktéři, kteří ostatní aktéry seznamujís konkrétními normami a šiří tyto normy. Termín „nositelé a zprostředkovatelé norem (norm entreprenever), pochází z francouzského slova "entrepreneur", cožznamená podnikatel či realizátor projektu. $V$ politologii a mezinárodních vztazích je koncept nositele a zprostředkovatele aplikován např. na policy inovátory, aktéry vytvářející politickou agendu a vnášející určitá témata do politiky, morální aktéry i epistemická společenstvi ${ }^{11}$.

Do politologického diskurzu zanesly termín „nositelé a zprostředkovatelé norem" Martha Finnemore(ová) a Kathryn Sikkink(ová) (1998), když zkoumaly dynamiku mezinárodních norem a jejich „životní cyklus”, tj. jejich vznik, rozšiření a internalizaci. Podle obou autorek jsou nositelé a zprostředkovatelé norem kličovými aktéry ve fázi vzniku normy, a to až do okamžiku, který obě autorky označily za "tipping" nebo "threshold point", tedy jakýsi okamžik zvratu či prahový bod. Bod zvratu představuje okamžik, kdy normu přijme kritické množství států tak, aby se norma stala obecně platnou, resp. považovanou za obecně platnou (Finnemore a Sikkink 1998: 895 - 899). Nositelé a zprostředkovatelé norem zprostředkovávají určitou normu ostatním a přesvědčují je, aby danou normu přijali a řídili se jí. Nositelé a zprostředkovatelé norem se pokoušejí socializovat další státy, aby následovaly ty, které již normu přijaly. Nositelé a zprostředkovatelé jsou pro vývoj normy zcela nepostradatelní, nebot’ obracejí pozornost $k$ určitým tématưm nebo tato témata dokonce vytvářejí, a to použiváním určitého jazyka, který konkrétní téma pojmenovává, interpretuje nebo dokonce dramatizuje (Finnemore a Sikkink 1998: 897).

Vedle Finnemorové a Sikkinkové můžeme koncept nositele a zprostředkovatele norem nalézt např. i u Petera Andrease a Ethana Nadelmanna, Jeffreyho Checkela či Lawrence Lessiga. Andreas a Nadelmann hovoří o tzv. „transnational moral entrepreneurs". Transnacionálními morálními nositeli a zprostředkovateli mohou být podle obou autorů jedinci, nevládní organizace i státy, kteři stojí u zrodu mezinárodních prohibičních režimů, které omezují negativní jevy v mezinárodních vztazích jako např. mezinárodní organizovaný zločin, pirátství či prostituci. Tito aktéři mobilizují veřejné míněn a politickou podporu, a to jak doma, tak v zahraničí, iniciují vytváření podobně smýšlejících organizací v dalších zemích a pomáhají je vytvořit a hrají významnou roli při zanášení svého cíle do národního zájmu vlád (Andreas a Nadelmann 2006: 19).

Checkel hovoři o "tvưrcích norem” (norm-makers), což jsou ti aktéři, kteři stojíza difuzí, tj. rozšiřováním a pronikáním norem. K difuzi normy dojde v okamžiku, kdy „„je

11) Podle Lessiga mají, každá společnost a každý sociální kontext, sociální význam (social meaning) - tj. sémiotický obsah prípisovaný či přináležejicí určité činnosti nebo nečinnosti, prípadně stavu v konkrétním kontextu (Lessig 1995: 951). 
Norsko a Austrálii za tzv. střední mocnosti (middle power), Sebastian Harnisch a Hans Maull označuji Spolkovou republiku Německo za tzv. civilní mocnost (civilian power/Zivillmacht) a Gareth Evans, Nicholas Wheeler, Tim Dunne, Antonio Frencscheft a Andy Knight hovoři o Austrálii, Velké Británii a Kanadě jako o tzv. dobrých mezinárodních občanech (good international citizen).

I když každá z uvedených mezinárodně-politických rolí vykazuje různé sady znaků, několik znaků všechny zmíněné role sdílejí. Střední mocnosti, civilní mocnost a dobří mezinárodní občané zejména značně demokratizovali tvorbu a výkon vlastní zahraniční politiky, domácí a zahraniční politika jsou v jejich př́padě silně propojeny, aktivity směřujicí k zajištění bezpečnosti a blahobytu se netýkaji pouze jejich vlastních občanů, jsou ochotni omezit vlastní zisky ve prospěch obecného dobra a veřejných statků jsou si vědomi svého členství v mezinárodní společnosti a z toho vyplývajících závazkơ a násilí používaji jako poslední volbu (Wheeler a Dunn 1998; Francescheft a Knight 2001; Rutherford, Brem a Matthew 2003; Harnisch a Maull 2001; Cooper, Higgott a Nossal, 1993; Keating 2002; Pratt 2002; Matthew a Pratt 1988).

Analýzy jmenovaných badatelů ukazuji, že v mezinárodním systému existuj státy a skupiny států, které se svými hodnotami a aktivitami liší od ostatních: civiln mocnosti, střední mocnosti a dobři mezinárodni občané se chovají „lépe” než ostatní, jejich motivace jsou zpravidla morální, háji "dobré” a „správné" věci a pokoušejí se je vtělit do mezinárodní politiky. Střední mocnosti, civilní mocnosti i dobři mezinárodni občané jako tři typy postmoderních států jsou např. výrazně aktivní při prosazován konceptů alternativních či komplementárních ke konceptu národní bezpečnosti (např. koncept široké bezpečnosti a ještě výrazněji koncept lidské bezpečnosti prosazovanỳ a zprostředkovávaný prostřednictvím OSN a Human Security Network), zasazuji se za zákaz některých typů zbraní, aktivně přistupují k rozvojové spolupráci apod. V souvislosti s naší tezí o postmoderních státech jako nositelích a zprostředkovatelích kantovské etiky se domniváme, že "jinakost" středních a civilních mocností a dobrých mezinárod ních občanů souvisí mj. s tím, že se jedná o postmoderní státy, v jejichž politické kultuře zakořenil princip participace a které cítí zodpovědnost i za ty, kteři nejsou jejich občany.

\section{Závěr}

Uvažovat o kantovské etice jako o prípadném řídícím principu zahraničně a mezinárodně politického jednání bylo umožněno zejména oslabením vestfálského charakteru mezinárodního systému a transformací některých společností projevujici se zformováním globální občanské společnosti a zvýšením ambicí jedinců a dalších sociálních aktérů podílet se na tvorbě a výkonu zahraniční politiky. Kořeny hlubokých společenských, ekonomických a politických změn, které vedly $\mathrm{k}$ ústupu vestfálského paradigmatu, nalezneme již $\checkmark 70$. letech 20 . století. $\vee$ tomto období se některé společnosti začínaji posouvat od modernity $\mathrm{k}$ postmodernitě, klasická státocentrická politika byla narušena vzájemnou 
požadavků mezinárodní společnosti ${ }^{14}$ (Vincent 1979: 59). Zdrojem kantovské etiky a místem, kde dochází k formulování práv, je světová společnost, místem jejich uplatňování je pak společnost států. Aby mohla být určitá kritéria dobra a morálky uplatněna na úrovni společnosti států, musejí být tato kritéria zanesena do mezinárodního diskurzu a mezinárodního práva. Na základě předložených a analyzovaných př́kladů z chován některých států $v$ soudobém mezinárodním systému jsme dle našeho soudu výrazne ověřili hypotézu, že jako nositelé kantovské etiky a jako zprostředkovatelé morálních hodnot a principů mezi světovou společností a mezi společností států působí postmoderní státy, které na sebe berou břímě „služebníků lidstva” a vystupuji v úlohách dobrých mezinárodních občanů či civilních mocností.

nech. Tato transformace zahrnovala zvy̌šní zájmu jedincư o zapojení do aktivni komu nikace a participace na tvorbě dilč̌ich politik (policies) i procesu politiky (politics) otevření a demokratizaci uzavřeného procesu tvorby zahraniční politiky a proměnu resp. rozšíření pojetí moci, která přestala být vnímána pouze jako nástroj donucení. Zmíněná vnitřní politická, kulturní a společenská transformace souvisí s přechodem některých společností od modernity $k$ postmodernitě. Přechod k postmodernitě vyústi $\checkmark$ demokratických společnostech v posílení participativní demokracie včetně zvýšen zájmu politických institucí a tvưrců politických rozhodnutí o veřejné mínění. Demokratizace zahraniční politiky, posílení participativní demokracie a aktivní zájem domácích a transnacionálních aktérů o zahraničně a mezinárodně politický proces vytvořily z mezinárodní politiky dvoustupňový proces. $V$ první fázi tohoto procesu vznikají zájmy států, které se formují uvnitř států na základě působení různých domácích i mezinárodních societálních aktérů v rámci domácího politického procesu, ve druhé fázi jsou pak hlavními aktéry státy, které hájí zájmy societálních aktérů, které reprezentuji. ${ }^{12}$

Náš článek snesl argumenty pro tvrzení, že přechod k postmodernitě umož nil určité skupině států překonat stav, kdy rámce pro morálku založené na státocentrické perspektivě a perspektivě světové společnosti ${ }^{13}$ nebyly slučitelné (srovnej např. Vincent 1986 nebo Bull 2002) a morální požadavky světové společnosti byly antitezí

12) Autorem pojetí mezinárodní politiky jako dvoustupňového procesu je A. Moravcsik (1993). Moravcsik dvoustupňové pojetímezinárodní politiky aplikoval při analýze evropského integračniho procesu.

13) Světová společnost je společnost, která je inkluzivnější než mezinárodní společnost, rozšiřujice určitá práva na jedince a skupiny na celé Zemi (Vincent 1986: 105). Světová společnost zahrnuje jedince, nevládni organizace a lidstvo jako celek. Žádný z těchto aktérú nedominuje ostatním. Jako další varianta termínu světová společnost jsou použivány ter míny globálni společnost nebo globálníobčanská společnost (Buzan 2004: xviii a 2).
Literatura

ADLER, Emanuel; BARNETT, Michael (1998): Security Communities. Cambridge: Cambridge University Press. AMSTUTZ, Mark R. (2008): International Ethics. Koncept, Theories, and Cases in Global Politics. Third edition New York Rowman \& Littlefield Publishers.

ANDREAS, Peter; NADELMANN, Ethan (2006): Policing the Globe. Criminalization and Crime Control in International Relations. Oxford: Oxford University Press.

BULL, Hedley (2002/pưvodně 1977): The Anarchical Society. A Study of Order in World Politics. Third Edition. With Forewords by Andrew Hurrell and Stanley Hoffmann. Houndmills, Basingstoke, Hampshire Palgrave Macmillan.

BULL, Hedley (1979): Human Rights and World Politics. In Pettman, Ralph (ed), Moral Claims in World Affairs. Londýn: Croon Helm Ltd., s. $79-9$.

BUZAN, Barry (2004): From International to World Society? English school theory and the social structure of Globalisation. Cambrdige: Cambridge University Press.

CARR, Edward H. (1939): The Twenty Years' Crisis, 1919 - 1939. An Introduction to the Study of International Relations. New York: HarperCollins Publishers.

CíSAŘ, Ondřej (2005): Sociální hnutí, nevládni organizace a zájmové skupiny ve viceúrovňové struktuře U: prístup ke studiu. In Fiala, Petr; Strmiska, Maxmilián (eds.) Víceúrovňové vládnutí: teorie, přistupy

utions, and National Identity in Contemporary Europe. International Studies Quarterly, $43(1): 83-114$
14) Mezinárodní společnost vznikne, když „dva či více států jsou spolu natolik v kontaktu a natolik vzájemně ovlivñuji svá rozhodnutí, že je to nutí chovat se - alespoň do určité mirry-jako části celku ... společnost států existuje, když si je nějaká skupina států vědoma určitých společných zájmů a hodnot; tyto státy vytváréjí společnost, jejižžlenové jsou navzájem svázáni určitou sadou pravidel a společně sdilených instituci" (Bull, 2002: $9-10$ a 13). 
COOPER, Andrew F.; HIGGOTT, Richard A.; NOSSAL, Kim Richard (1993): Relocating middle powers. Australia and Canada in a changing world order. Vancouver. UBC Press.

COOPER, Robert (2000): The post-modern state and the world order. Londýn: Demos.

COOPER, Robert (2003). The breaking of nations. Order and chaos in the twenty-first century. Ney York: Grove Press.

DWIVEDI, O. P. (1987): Moral Dimensions of Statecraft: A Plea for an Administrative Theology. Canadian Journal of Political Science, $20(4): 699-709$.

EVANS, Gareth; SAHNOUN, Mohamed (2002): The Responsibility to Protect. Foreign Affairs, 81 (6), staženo z databáze ProQuest, nestránkováno.

FINNEMORE, Martha; SIKKINK, Kathryn (1998): International Norm Dynamics and Political Change. In ternational Organization, 52 (4) (Autumn 1998): 887 - 917 .

RENCESCHEFT, Antonio; KNIGHT, W. Andy (2001): International(ist) citizenship: Canada and the International Criminal Court. Canadian Foreign Policy, $8(2): 51-74$

FROST, Mervyn (2001): The ethics of humanitarian intervention: protecting civilians to make democratic citizenship possible. In Smith, Karen E, Light, Margot (eds.), Ethics and Foreign Policy, Cambrdige, Cambridge University Press, s. $33-54$

HAAS, Peter M. (1992): Introduction: Epistemic Communities and International Policy Coordination. In Has, Peter M. (ed.): Knowledge, Power, and International Policy Coordination, Special Issue of Internati(1): $1-35$

HARNISCH, Sebastian; MAULL, Hanns W. (2001): Introduction. In Harnisch, Sebastian; Maull, Hanns W. (eds.), Germany as a Civilian Power? The foreign policy of the Berlin Republic, Manchester, Manchester University Press, s. $1-9$

HYNEK, Nikola - WAISOVA, Šárka (2006): Agenda lidské bezpečnosti a koncept střední mocnosti na pozadí kanadské zahraničnni politiky. In: Waisová, Šárka (ed.), Chudoba a bohatstvi v současném světě, Plzeñ, Vydavatelství a nakladatelstvi Aleš Čeněk, s. 23-38.

HYNEK, Nikola (2005): Anglická škola a teorie mezinárodnich vztahư: obsahový vesmír, akademický svět a kritiky pristupu. Mezinárodni vztahy 40 (2): $76-89$.

INGLEHART, Ronald (1997): Modernization and Postmodernization. Cultural, Economic and Politica C

JACKSON, Robert (2005): Classical and Modern Thought on International Relations. From Anarchy to Cosmopolis. Houndmills, Basingstoke, Hampshire: Palgrave Macmillan.

KANT, Immanuel (1995/1795): K věčnému míru, Filosofický traktát/Zum ewigen Frieden. Praha: Oikoy

KENNAN, George F. (1985): Morality and foreign policy. Foreign Affairs, 64 (Winter 1985/1986): $205-218$ KEATING, Tom (2002): Canada and World Order. The multilateralist tradition in Canadian foreign policy. Second edition. Oxford: Oxford University Press.

KAPLAN, Robert (2002): Válečnická politika. Proč vưdči role vyžaduje pohanský étos. Střední Evropa, 18, listopad 2002: 13-32.

LESSIG, Lawrence (1995): The Regulation of Social Meaning. The University of Chicago Law Review, $62(3): 943-1045$

MATTHEW, Richard A. (2003):. Middle Power and NGO Partnerships: The Expansion of World Politics, In Rutherford, Kenneth R; Brem, Stefan; Matthew, Richard A., Reframing the agenda. The Impact of NGO and Middle Power Cooperation in International Security Policy, New York, Praeger Press, 5. 3- 20.

MORGENTHAU, Hans J. (1993): Politics among nations. The struggle for power and peace. Brief edition. Revised by Kenneth W. Thompson. New York: McGraw-Hill.

NEUMANN, Iver B. (2005): John Vincent a anglická škola mezinárodních vztahư. In Neumann, Iver B Waever, Ole (eds.), Budoucnost mezinárodnich vztahủ, Brno, Centrum strategických studii, s. 47-75. PENZ, Peter (2001): The Ethics of Development Assistance and Human Security: From Realism and Sove couver, UBC Press, s. $38-57$

POJMAN, Louis P. (1990): Ethics. Discovering right and wrong. Belmont: Wadsworth Publishing Company. POPPER, Karl Raimund (1994a): Otevřená společnost a její nepřátelé I. Uhranutí Platónem. Praha: Oikoy-

POPPER, Karl Raimund (1994b): Otevřená společnost a jeji nepřátelé II. VIna proroctví: Hegel, Marx a co následovalo. Praha: Oikoymenh.

PRATT, Cranford (1994): Middle Power Internationalism and Global Poverty. In Pratt, Cranford (ed.), Middle Power Internationalism. The North-South Dimension. Montreal, Quebec, Ontario, McGill-Queen's University Press, 5. 3-25.

RUGGIE, John Gerard (1992): Multilateralism: the anatomy of an institution. International Organization, $46(3): 561-598$.

RUGGIE, John Gerard (1993): Territoriality and Beyond: Problematizing Modernity in International Relations. International Organization, 47 (1) (Winter, 1993): $139-174$

SØRENSEN, Georg (2005): Stát a mezinárodni vztahy. Praha: Portál.

SØRENSEN, Georg (2006): The Transformation of the State. In Hay, Colin; Lister, Michael: Marsh, David (eds.) The State. Theories and Issues, Houndmills, Basingstoke, Hampshire: Palgrave Macmillan, s. 190 - 208

ŠEDIVÝ, Jiř́ (2002): Střet identity? USA a Evropa po 11. záři. Mezinárodni vztahy 37 (4): 5 - 25

VINCENT, John R. (1979): Western Conceptions of a Universal Moral Order. In Pettman, Ralph (ed.), Moral Claims in World Affairs, Londyn: Croon Helm Ltd., 5. 52-78.

VINCENT, John R. (1986): Human Rights and International Relations. Cambridge: Cambridge University

WAISOVÁ, Šárka (2002): Teorie mezinárodnich režimů. Mezinárodni vztahy 37 (2): 49 - 66.

WAISOVA, Šárka (2005): Bezpečnost - Vývoj a proměny konceptu. Plzeň: Vydavatelství a nakladatelstvi Aleš Čeněk.

WAISOVA, Šárka (2007): Smlouvy bez meče nejsou nic než slova: Moc a etika v mezinárodních vztazích. In Rosìlek, Přemysl a kolektiv, Politická filozofie. Aktuálni problémy, Plzeň, Vydavatelství a nakladatelstvi

WEBER, Max (1998): Metodologie, sociologie a politika. Kapitola „Politika jako povoláni”. Praha: Oikoymenh

WENDT, Alexander (1999): Social Theory of International Politics, Cambridge Studies in International Reations. Cambrdige: Cambridge University Press.

WHEELER, Nicholas J.; DUNNE, Tim: 1998. Good international citizenship. A third way for British foreig policy. International Affairs (Royal Institute of International Affairs), 74 (4): 847 - 870 .

WIGHT, Martin (1978): Power Politics. Edited by H. Bull and C. Holbraad. Londýn: Royal Institute of International Affairs. 
rozhovor

Lukáš Pecha doc. PhDr. Petr Charvát, DrSc. 


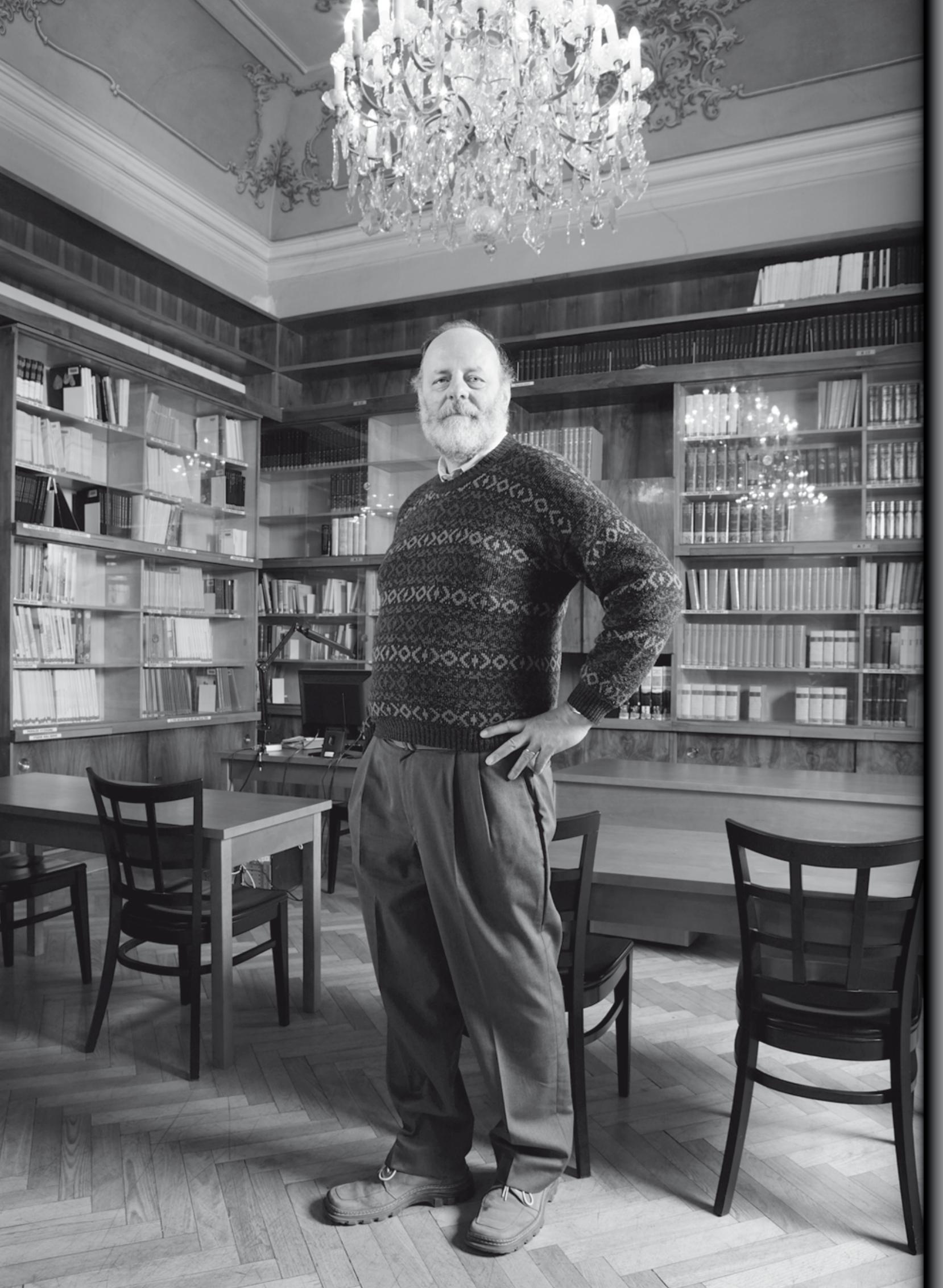

\section{Lukáš Pecha}

\section{Rozhovor s doc. PhDr. Petrem Charvátem, DrSc.}

V lednu 2009 oslavil významné zivotní jubileum doc. PhDr. Petr Charvát, DrSc., mezinárodně uznávaný archeolog a odborník na dějiny starověké Mezopotámie, který přednáši na Centru blizkovýchodních studií Katedry antropologických a historických věd FF ZČU. Při této př́ležitosti jsme jej požádali o krátký rozhovor.

Jak ses dostal k zájmu o starověké kultury Mezopotámie? Byl to výsledek nějaké náhody, nějakého "znamení shưry", nebo spiš výsledek dlouhodobého a cílevědomého hledání?

O děje minulé jsem se zajímal vždy, a již jako chlapec a rád jsem si pro sebe vyprávěl, ba i tvořil př́běhy. Byla to však vskutku náhoda. Roku 1960 přijal mưj otec, MUDr. Zdeněk Charvát, jmenování profesorem lékařské fakulty univerzity v Bagdádu. Hned roku 1961 jsme se do Iráku mohli vypravit všichni a tu jsme najednou spatřil památky kultury o tisíciletí starší, než byla ta naše. Fascinovalo mne to a asi už mi to zůstalo.

Je známo, že se zabýváš nejen dějinami starověké Mezopotámie, ale také vývojem Čech v raném středověku. Stalo se ti někdy, že tě studium českých dějin inspirovalo při výzkumu dějin Mezopotámie, a naopak?

Ač to zní neuvěřitelně, musím říci, že velice často. Při probírání nejrưznějších otázek mezopotamské či české státnosti jsem čím dál tím častěji přicházel na to, že vytváříme-li společnost určité složitosti, která má v nadregionálním měřítku fungovat, počet řešení je 
definovaný a zpravidla velmi nízký. Ze shodných rysů mưžeme namátkou jmenovat třeba tzv. služebné vsi, o jejichž existenci se ted’v Čechách debatuje, ačkoli na starověkém Blíz kém Východě to byla záležitost celkem běžná. Řada otázek dálkového obchodu, jeho sezonni průběh, dơležitá role mist setkávání, ale také otázky správy z regionálních ústředí, zásobování státních organismů redistribucí, život a zvyky královského dvora - tam všude lze shledávat paralely a shody. $V$ jedné oblasti se to ovšem říci nedá. Starověkỳ Blízký Východ neznal exkluzivní náboženství, jejichž vyznávání by vylučovalo úctu k božstvưm jiných, i když někdy neodolal pokušení do tohoto směru sklouznout. V otázkách boje za víru pravou a jedinou proto nenalézám v historickém vývoji starověkého Blízkého Východu a středověkých českých zemí paralely.

Našel sis v mezopotamských dějinách nějakého „oblíbence”, s nímž by ses mohl ztotožnit?

Ted'jsi mě dostal. Dlouho jsem choval záměr zabývat se podrobněji Lugalzagesim, králem Ummy, který mi vždy připadal nespravedlivě zkrácený, když se hovořilo o tom, že první teritoriální říši v mezopotamských dějinách vytvořila staroakkadská dynastie. Pak tenhle vztah nějak vyvanul a v dané chvíli vlastně nevím. Pokoušel jsem se najít bližši vztah ke Gilgamešovi, ale nakonec jsem usoudil, že je přece jen asi přiliš uzavřen do svého kulturního vzorce. $V$ poslední době mne začala intenzivně zajímat postava krále Artuše jako nadčasové podobenství spravedlivého vládce, který, jsa člověkem, nemưže zůstat spravedlivý navždy a musí svou zem zanechat raádění lidského sobectví, ješitnosti, ctižádosti a chamtivosti. Vzhledem k tomu, že král Artuš představuje nejspíše specifický odraz blízkovýchodního mýtu o Mithrovi, bohu spravedlivém a vševidoucím, pánu času a zvěstovateli vítězství dobra a spravedlnosti, osměluji se přiřadit se k družině tohoto vládce.

\section{Jaký nejsilnější zážitek ti poskytlo studium starověkých dějin?}

Když jsem v letech 2003-2004 pracoval v Univerzitním muzeu archeologie a antropologie Pennsylvánské univerzity ve Filadelfii (UM), dostalo se mi díky nesmírné blahovůli a dơvěře vedení jeho Near Eastern Section př́ležitosti velmi podrobně se seznámit se sbírkou archeologických nálezů z města Uru, získaných Woolleyho expedicí a uložených dnes ve sbírkách UM. Probíral jsem se tehdy zejména pečetěmi na hlíně z urských vrstev označovaných jako SIS (asi 3000-2700 př. n. I.). Některé tyhle pečeti byly sejmuty ze dveři skladištních prostor, když byla hlína ještě měkká, a smáčknuty, aby se úředníkưm lépe odnášely do královské registratury, kde se kontroloval správný stav dodávek. Pamatuji se, jak jsem jednu $z$ těchto hrud hlíny vzal poprvé do ruky a prsty $m$ takřka automaticky vklouzly do prohlubní, zanechaných v hlíně rukou toho, který kdysi hliněnou plombu smáčkl. Uvědomil jsem si tehdy, že tvárná hlína přijala otisk ruky někoho, který žil před bezmála pěti tisíci lety, a že já ted' tomu člověku vlastně tisknu ruku. To byl zážitek dost silný.
Co je podle tvého názoru největší chloubou a největší ostudou asyriologie?

Největši chloubou discipliny je bezesporu fakt, že se vůbec podařilo klínové písmo roz luštit a číst tak obrovské množství dokumentů z doby, která by jinak zůstala němá. $Z$ toho ovšem vyplývá také nejtemnějši stín asyriologie. Vědu dělaji lidé, a vědu tak „prastarou a převzácnou”, jako klínopis, dělají lidé dosti specifického talentu, mimořád ného nadání, ale samozřejmě také osobnosti ostrých světel a hlubokých stínů. Jeden kolega situaci nedávno vtipně shrnul výrokem, že někteří z nás jsou monády dokonale uzavřené proti vlivům z vnějšího prostředí a komunikující výhradně samy se sebou. To, co mi v asyriologii nejvíc chybí, je esprit de corps, jaký má celá řada jiných humanitních věd - schopnost držet spolu.

Bylo by jistě chybou považovat starověkou Mezopotámii za mrtvou kulturu, která již dnešnímu člověku nemá co řici. $V$ jakých oblastech jsme nejvice zavázáni svým předkům ze starověké Mezopotámie?

Každodenně užíváme vynálezů, o kterých si vůbec nejsme vědomi, že vzešly od obyvatel staré Mezopotámie. Počínaje zemědělstvím, což už je konstatování téměř banální, ale třeba včetně uživání peněz, vynálezu a zavedení (tehdy stabilního) bankovního úroku. Jedna z posledních publikací oboru nese výstižný název „Democracy's ancient ancestors". Politický diskurs o povaze veřejné moci - zda totiž pochází ze sfér nadpřirozených, či zda je ustavována vưlí občanů - započal v Mezopotámii v 26. století př. n. I. Nebudu samozřejmě hovořit o vědách, matematice a geometrii, počitání kvadratických rovnic, zavedení nuly, propočtu doby oběhu Země kolem Slunce nebo sestavení tabulek zatmění Měsíce. Je zbytečné připomínat, jak hluboce je mezopotamskou kulturou prosycena Bible. Za připomenutí ovšem stojí, že za první užití pojmů jako je „spravedlnost”, "hřích" či „vina” vděčíme sumerštině.

Jaké jsou perspektivy světové asyriologie na prahu 3. tisíciletí? Na jaké problémy se bude muset zaměřit a jakým výzvám bude muset čelit? A dokáže to vůbec? Má tato věda nějakou budoucnost?

Vidím asyriologii na počátku velkých objevů. Současná exploze informačních a elektronických médií umožňuje v míre dosud nevídané zpracovávat obrovské objemy informací. Jedním z jejích hlavních problémů je však, jak řečeno výše, „komunikační šum” v oblastech styku s jinými vědními obory. Věda budoucnosti bude vědou spolupráce, kooperace odlišných vědních oborů, které se zaměří na jeden a tentýž problém z různých úhlů pohledu tak, aby se zřetelně objevily všechny jeho postižitelné aspekty. Jako všechny ostatní skutečně hloubkové obory bude asyriologie muset čelit snahám o zploštění, nepřípustné zjednodušení a ideologickou manipulaci. Zda to dokáže, to bude záviset na nás samých, na našich studentech a následovnících a nástupcích. Asyriologie má takovou budoucnost, jakou si zaslouží. Je možné si představit, že právě tak, jako v čase vznikla, tak i v čase zanikne. Na druhou stranu Ize na základě skutečnosti, že texty, ležící 
po tisíciletí v prachu, špíně a zapomnění byly posléze nalezeny, pečlivě uloženy, přečteny, zpřístupněny a že tak jejich tvưrci po tisíciletích mlčení znovu promluvili, chovat pev nou naději, že osud zamýšlel nedopustit zánik památek na civilizaci, jíž za tolik vděčíme.

Když opustíme globální měrítko a přeneseme se do našich domácích poměrů, jaké jsou hlavní úkoly pro současnou generaci asyriologů a jejich následovniky?

Obávám se, že je to velmi prosté. Asyriologii v českých zemích je třeba především zachovat při životě. U malých oborů v malých národech je jejich existence vždy ohrožena, at’ již z jakéhokoli důvodu. Jsem hluboce přesvědčen o tom, že zánikem české asyriologie by vzdělanost a kultivovanost české společnosti doznala nenahraditelné škody. $\mathrm{Na}$ ším úkolem je tedy zaprvé, jak se kdysi řikalo, vydržat'. Za druhé, a to pokládám za conditio sine qua non, udržet současnou vysokou kvalitu našeho asyriologického bádání. Konečně za třetí, je třeba udržet aspoň minimálni stupeň komunikace v oboru a též jeho soudržnosti, abychom obstáli v současné epoše útoku na základní premisy a parametry skutečného vědeckého bádání.

Podili'š se na činnosti transversální skupiny „Glyptic and Art History”, která je součástí prestižního mezinárodního projektu ARCANE. Pracovní jednání této skupiny se ko nalo v Plzni v listopadu 2006 a znovu proběhlo $v$ dubnu 2009. Můžeš ve stručnosti představit tento projekt, jeho cíle a dosavadní výsledky?

Projekt ARCANE Ize asi nejlépe charakterizovat uvedením jeho plného názvu „Associated regional chronologies of the Ancient Near East". Jde o záměr financovaný z prostředků European Science Foundation, trvající v letech 2006-2012, na němž v této chvíli pracuje 128 badatelů z 25 zemí Evropy, Turecka, Izraele a USA. Hlavním záměrem projektu je předložit spolehlivou chronologii hmotné kultury Blízkého Východu ve třetím tisícilet před občanským letopočtem. Vyplňuje tak mezeru mezi posloupností čtvrtého tisíciletí, zpracovanou americkými kolegy zejména z iniciativy Mitchella Rothmana z Widener University v tzv. chronologii ze Santa Fé, a sekvencí tisíciletí druhého, zpracovávanou podobným mezinárodním projektem vedeným Manfredem Bietakem $z$ vídeňské univerzity. Projekt ARCANE sestává z celkem jedenácti regionálních skupin, pokrývajících jednotlivé významné oblasti Blízkého Východu od západní Anatolie a Kypru až po západní Írán. Tuto základní sestavu projektu doplňují tři skupiny transverzální, čili česky asi tematické. Jde o skupiny TG01 "History and Epigraphy”, TG02 "Glyptic and Art History” a TG03 „Radiocarbon Dating”. Jejich úkolem je vypracovat chronologie jednotlivých kategorií historicky citlivého materiálu, které by sloužily jako opory a svého druhu kontroln mechanismy pro zakotvení časových posloupností definovaných regionálními skupinami ARCANE. Západočeská univerzita v Plzni, která je jediným českým účastníkem projektu se na jeho činnosti podilí v mé osobě. Spolu s paní Holly Pittman, profesorkou dějin umění na Pennsylvánské univerzitě ve Filadelfii v USA, pưsobíme jeko vedoucí tematické skupiny TG02 "Glyptic and Art History". Staneme se také vydavateli jedné ze závěrečných publikací projektu se stejným titulem. Další informace o projektu ARCANE Ize nalézt na adrese http://www.arcane.uni-tuebingen.de/ (citováno 15. 5. 2009).

Děkuji za rozhovor. 
recenze

Francis Fukuyama, Ivo T. Budil /

Petra Burzová

Alexander Broadie / Svatava Heinlová 
Petra Burzová

Zakladatelia Západu, koniec dejín a posledný človek (komparatívna perspektíva)

BUDIL, Ivo T.: 2007. Zakladatelé Západu a poslední člověk. Esej o zdrodu a zániku západní civilizace. Ústínad Labem: Dryada.

FUKUYAMA, Francis: 2002. Konec dějin a posledni clověk. Praha: Rybka Publishers.

V tejto práci sa pokúsim o porovnanie dvoch publikácií, ktoré už svojím názvom napovedajú isté podobnosti a rozdiely: „Konec dějin a poslední člověk” (Francis Fukuyama) a „Zakladatelé Západu a poslední člověk. Esej o zrodu a zániku západní civilizace” (Ivo T. Budil). K základnému porovnaniu pridám aj vlastný náhlad na niektoré skúmané koncepty. Ukážem, že hoci je diagnostika stavu sveta u oboch autorov nápadne rozdielna, liečba je zase v mnohých momentoch vel'mi podobná.

Na začiatok náčrt záveru. Čo autorov v konečnom dôsledku odlišuje, je opatrný (ale principiálne fatalistický) optimizmus F. Fukuyamu a nefatalistický, ale výstraž ný pesimizmus I. T. Budila. Rozdiel je markantný hned'v úvode oboch pojednaní v troch bodoch:

1. v pomere Samuela Huntingtona k F. Fukuyamovi a otázke Západu vo svete,

2. v samotnom uchopení predmetu skúmania,

3. v rámci, z ktorého autori vychádzajú (s výnimkou spoločného spracovania

Nietzscheovho „posledného človeka”). 


\section{Samuel Huntington}

Strét civilizací Samuela Huntingtona je aj samotným F. Fukuyamom považovaný za „antitézu" Konce dějin. ${ }^{1}$ Zdá sa, že rozpor je nachádzaný v nezlučitel'nosti predstavy konca dejín na jednej strane a neprekonatel’nom strete civilizačných okruhov, ktoré budú v neustálom bojovom stave práve preto, že sa potrebujú (ako antitézy), na strane druhej. I. T. Budil v jednotlivých tézach rozpor nevidí, naopak "Samuel Huntington začíná hovorit tam, kde Francis Fukuyama svůj výklad končí." Huntingtonov partikularizmus vraj len rozvija Fukuyamov univerzalizmus. Budilova syntéza by sa dala podložit nie práve jednoznačným záverom Konce dějin, ktorý nás akoby zanecháva bez niektorých dôležitých implikácií. Čo s „povozmi”, ktoré do mesta preukázatel'ne nedorazili? Je vôbec isté že všetky z nich sa vydali po jedinej ceste, ktorú F. Fukuyama dokáže vidiet?? Nie je tých miest predsa len napokon viac? S. Huntington tvrdí, že áno, svet je rozdelený do civilizačných okruhov, ktoré poháňa ich vlastný thymos. Boj o uznanie preto stále zúri. F. Fukuyama naznačuje, že „Liberální demokracie, jež by v každé generaci dokázala vybojovat krátkou a rozhodnou válku $\mathrm{k}$ obraně své svobody a nezávislosti, by byla dalek zdravější a spokojenější než taková, která nezná nic jiného než trvalý mír." ${ }^{3}$ Ak by ma "nepriatel" na konci dejín nevyhnutne zmiznút', Západ by si ho možno bude musiet' vymysliet'. Zdá sa, že by nebolo úplne mylné sa domnievat', že tam smeruje aj Budilovo rozprávanie, islám predstavuje historickú výzvu a Západ by v jeho „iracionálnych výbuchoch megalothymie" ${ }^{\prime \prime 4}$ mal nájst' svojho štvrtého zakladatela.

\section{Človek Západu}

Francis Fukuyama nám predkladá dialektickú evolucionistickú predstavu dejín. Dejiny sú podla neho „chápané jako nedílný, souvislý evoluční proces, jehož součástí jsou zkušenosti všech národů ve všech dobách. ${ }^{15}$ Dejiny sú smerované a kumulatívne podobne ako moderné prírodné vedy. Zavrhuje cyklické dejiny, pretože (ako pri Kuhnových vedeckých revolúciách) zaniknuté civilizácie nie sú bez stopy nahradené novými, zanechávajú svoje dedičstvo a sú prekonávané lepšími alternatívami. Menej rozporná alternatíva sa vždy stavia nad rozpor predchádzajúcej. Smerovanie znamená smerovanie k niečomu. Konečný ciel' Konce dějin je liberálna demokracia s trhovou ekonomikou zaistujúca uspokojenie celého „"̌loveka ako človeka"6. Vzhladom na to, že ide o prirodzené uspokojenie „prosté rozporov", ktoré najlepšie zodpovedá "ludskej prirodzenosti" ${ }^{\prime 7}$, prirodzene k nemu budú skôr či neskôr inklinovat všetky spoločnosti. Lepší ideál sa už nenájde. To, čo nás poháňa, je snaha o uspokojenie thymu, ktorý je prítomný v každom človeku. Ku koncu dejín prišlo v roku 1989, odvtedy žijeme (rovine ideovo-vývojovej) $v$ dobe posthistorickej, zvyšok sveta zase v dobe historickej na ceste do posthistórie.

Budilove rozprávanie je príbehom jednej civilizácie, nie trvale udržatelného dejinného konceptu. Predkladá makrohistorickỷº obraz Západu tak, ako sa vyvijal v čase od svojich dávnych počiatkov až podnes. Celý príbeh sa nesie v duchu možného zániku. Západ bol utváraný, musel o svoje prežitie bojovat’ a dnes je, podobne ako niekol'kokrát predtým, v stave ohrozenia. Západ je síce jedinečný, pretože dokázal úspešne reagovat na historické výzvy, nie je však nesmrtelný. O to menej je definitívne jeho postavenie ako dominantnej svetovej civilizácie.

\section{Dejiny}

Tretím rámcovým rozdielom je hladisko teoretické. F. Fukyuama vychádza z Hegelove filozofie dejín v interpretácii Kojèva. Príbeh pána a otroka je dostatočne známy. F. Fukuyama svoj výklad, aj ked's istými výhradami, končí pri ich vzájomnom uznaní si dôstojnosti. Pracuje $s$ konceptom thymu ako tretou zložkou ludskej duše podla Platóna. Popri túžbe a rozume predstavuje thymos "sebeúctu" ale aj "vznětlivost", túžbu po uznaní dôstojnosti. Megalothymia je potom snaha o uznanie za nadradeného a isothy mia za rovného druhým. Koncept "prvého človeka” negatívne vymedzuje proti Hobbesovmu a Lockeovmu človeku a „posledného človeka” preberá od Nietzscheho (rovnako ako I. T. Budil). Ako si všimol I. T. Budil, a ako som naznačila v úvode, F. Fukuyama nepostráda pesimizmus vo vzțahu k modernite. Aj on predkladá kritiku modernej spoločnosti a načrtáva isté výzvy. Primárne sa však obáva vnútornej dekadencie, nie vonkajšieho nepriatela. Skôr než by bil na poplach sa zdá, že sa prikláňa ku Kojèvovej relatívne pokojnej rezignácii, nie však bez všadeprítomného želania, aby sme sa neprepadli do konzumného bezčasia.

Ivo T. Budil už úvodnou citáciou Arthura Gobineaua naznačuje líniu, z ktorej vychádza. Nadväzuje na výrazné mená myslitel’ov, ktorí rozpracovali vel'ké teórie svetových dejín, pričom citel'ná je tu fascinácia zrodom a zánikom civilizácií. Spomedzi množstva mien spomeniem Giambattistu Vica, Oswalda Spenglera, Immanuela Wallersteina a Arnolda Toynbeeho, ale aj Herberta Georga Wellsa, Gilberta Keitha Chestertona a (najmä) Friedricha Nietzscheho. Zrejmý je aj vplyv Samuela Huntingtona a Francisa Fukuyamu. I. T. Budil však žiaden predstavený teoretický rámec nepreberá, vychádza len z jednotlivých prvkov, ktoré aplikuje vo svojej vlastnej syntéze. Tak ako Victor Davis Hanson alebo Jared Diamond sa zamýšla nad prícinami úspechu a hegemónie Západu ktorú chápe ako (primárne) zvnútra a (následne) zvonka ohrozenú.

To, že Západ prežil a podla názvu jednej Hansonovej knihy stále vyhráva, nie je spôsobené logikou jednosmerného evolucionizmu, naopak, Západ si svoje postave nie musel vybojovat'. Tu I. T. Budil zapája Toynbeeho tézu: „Každá civilizace či ,společnost' musí obstát před velkými historickými zkouškami a ,výzvami', na nichž prokazuje svou vitalitu, cílevědomost a životaschopnost. Mnohé společnosti obstojí, ale za cenu vytvoření strategie, která je vjiném dějinném kontextu zavede do slepé uličky." ${ }^{\prime \prime} \vee$ záve re treba hladat’ varovanie pred dnešnou stratégiou Západu, ktorá pravdepodobne nie celkom vážne zohladňuje "vel'kost”” historickej výzvy dnešného „islámu” (čiže dnešná 
cesta - alebo skôr mnohé z načrtnutých ciest - je síce schodná, ale slepá), ktorý podobne ako Západ „dokázal preukázat”" historickú odolnost'.

Dalši výrazný koncept je Wallersteinova teória svetového systému, ktorá z makrohistorického hladiska rozpracováva teóriu závislosti. ${ }^{10}$ I. T. Budil ju ako celok (s ideologickými implikáciami) odmieta, svetový systém si pre svoje potreby upravuje na dynamickú súhru „mezi jádrem [ohnisko rozvoje, kreativity a dynamizmu], periferii [suroviny a pracovná sila, jej kultúrna imaginácia je spútaná] a marginální zónou [k podnetom pristupuje selektívne, kultúrna identita je zachovaná, vzdoruje kultúrnej imaginácii jadra, stáva sa potenciálnou alternatívou]..."11 $\mathrm{V}$ marginalite je priestor $\mathrm{n}$ konsolidáciu, preto „....marginální společenství má př́ležitost se stát jádrovou civilizací, pokud je konfrontováno s velkou historickou, enviromentální nebo ekonomickou výzvou, jejiž úspěšné překonání je prvním krokem k vybudování civilizace."12 Budilova koncepcia je externalistická, tvár Západu sa vyformovala tlakom druhého. Odtial' "zakladatelia” Západu. „Evropa potřebuje ke svému vymezení Asii jakožto „toho druhého”, jehož je antitezí a jímž se cítí být permanentně ohrožována, at' to byly Trójané, Foiničané, Peršané, Parthové, Arabové, osmanští Turci nebo Rusové. ${ }^{13}$ Moderný Západ založili prorok Muhammad (saaw), Džingischán a Süleyman Nádherný.

Na všetky „hrozby" Západ podla I. T. Budila (vo „výhodnom” postavení marginality) reagoval konsolidáciou, zjednotením a intelektuálnym a kultúrnym vymedzením. Osmanský tlak inicioval odloženie náboženských sporov a revolúciu vo vojenstve. Dôvod pre ktorý sa dnes Západ nemôže do marginality stiahnuṫ, je priam existenčný - ak chce Západ prežit', musí si „obhájit” a znovu potvrdzovat' svoje postavenie „hegemóna”.

Na podobné vízie by F. Fukuyama pravdepodobne odpovedal optimizmom (aj ked' neskôr sa vrátim k odvrátenej strane tohto „ dejinného optimizmu”): „....natolik jsme si zvykli očekávat, že budoucnost přinese špatné zprávy o stavu a zabezpečeni slušných, liberálních a demokratických politických praktik, že máme problémy s rozpoznáním př́ipadných dobrých zpráv. ${ }^{114}$ Podla F. Fukuyamu je rozširujúca sa oblast' pod priamym vplyvom liberálnej demokracie a vol'ného trhu jediná životaschopná civilizácia bez alternatív, ku ktorej bude svet smerovat'. Napriek tomu, že na svete môžu existovat' konzervatívne oblasti, modernitu to nezastaví. „Modernita spočivá na kulturním základě. Liberální demokracie a volný trh nefunguji všude a za každých podmínek. Nejlépe se osvědčili ve společnostech vyznávajících určité hodnoty, jejichž původ nemusí být zcela racionální. Není náhodou, že moderní liberální demokracie se poprvé objevila na křest’anském Západě, univerzalismus demokratických práv lze totiž považovat za sekulární formu křest’anského univerzalismu. ${ }^{115}$ Ale selektívna modernita nie je možná (ako bolo možné selektívne preberanie impulzov z marginálnej izolácie): „Všechny země, které procházejí ekonomickou modernizací, nutně vzrưstající měrou připomínají jedna druhou; musejí se národnostně sjednocovat na základě centralizovaného státu urbanizovat, nahrazovat tradiční formy společenského uspořádání, jako jsou kmen, sekta a rodina, ekonomicky racionálními, založenými na funkci a účinnosti, a poskytnout vzdělání všem občanům." ${ }^{\prime 16}$

\section{Tancujúca hviezda}

Oboch autorov spája kritika toho, čo by sme mohli nazvat' konzumnou a principiálne is othymickou spoločnostouu. Obaja naznačujú aj možné riešenie (hoci sú tu významné variácie v dôraze na jednotlivé výzvy): prebudenie "chaosu v nitru”, návrat iracionálna (v podobe náboženského citu a „poézie"), vytýčenie ciela (a spoločných hodnôt) ${ }^{17}$, prijatie prirodzenej nerovnosti a snaha o „prekonanie sa”, láska k múdrosti a velkým činom, konsolidácia proti rozdrobenosti (ktorá spúšta "neblahé” megalothymické vášne), vymedzenie sa (proti nepriatelovi), návrat prirodzeného hrdinstva. $S$ istou váhavostou by sa dalo tvrdit', že jedným z odporúčaní (na strane I. T. Budila a S. Huntingtona) by bolo a prehodnotenie "kognitívnej netolerancie”, „sociálnej tolerancie a rovnosti práv” a "multikulturalizmu". Je možné, že F. Fukuyama s A. Kojèvom by si želali boj a nepriatela, ktorý by prebudil a dal zmysel bezduchým posledným ludom (Západu), zatial'čo I. T. Budi s S. Huntingtonom by posledným človekom (Západu) zatriasli, aby ho upozornili na to že boj dávno prebieha. Netreba sa však vracat’ spät do minulosti, pán a otrok sa môžu navzájom uznat', pokial' bude uznanie založené na základe prekonania biologických potrieb (zvierata v nás), na úcte $\mathrm{k}$ múdrostij ${ }^{18}$ a hrdinstvu, zmysluplných výkonoch, hlbokom prežívaní a statočnosti. Takéto rozriešenie dilemy uspokojenia thymu by mohlo fungovat' v západnej spoločnosti. V Budilovej eseji však vidíme prenesenie problému pána a otroka na vyššiu ako individuálnu rovinu, na rovinu civilizácií. Na konci ich príbehu by teda mohol stát posledný Západ. Ale podobné riešenie $v$ tejto rovine ( $v$ hypotetic kom medzicivilizačnom boji o uznanie) esej neponúka.

\section{slám}

Jedným z najsilnejších miest Zakladatelov Západu je prirovnanie možnej budúcnosti Západu (po konci dejín) ku Stroju času H. G. Wellsa. „Eloiové a Morlokové” predstavujú postihistorických posledných ludí Západu, ktorí žijú v isothymickom bezčasí a príslušníkov civilizácií ovládaných megalothymiou. $\vee$ konečnom dôsledku by Morlokmi v zmysle oboch rozprávaní mohol byt stále historický islámsky fundamentalizmus. Jedným z jej prejavov by mohol byt' útok z 11. 9., ktorý vyvolal medzi potenciálnymi posthistorickými poslednými l'ud’mi "aztécky” šok. Hlboké zdesenie (podobne ako tragické „výstrelky" megalothymických totalitných režimov) by však podla I. T. Budila nemalo viest' $\mathrm{k}$ zavrhnutiu thymu, pokial'by sa ho Západ vzdal, mohol by ho conquistadorsko-islámsky Morlok začat' "pliživo" požierat'. Zlyhanie môže priniest' ", neobyčejně agresivní formu iracio nální megalothymie, která ohrozí Západ uspokojený idylickou souhrou touhy a rozumu realizujicí se ve vyspělých technologiích saturujicich konzumní způsob života ,bez hra- 
nic ${ }^{\prime \prime} .{ }^{19}$ I. T. Budil cituje Chestertona: „tuto nebývalou lhostejnost, tento nebývalý zasněný egoismus, tuto nebývalou samotu miliónů v davu musí něco prolomit." Dalo by sa povedat' (v zmysle I. T. Budila a Huntingtona), že hispánsko-islámsky Morlok už je medzi nami a liberálny multikulturalizmus je nebezpečný lahostajný a zasnený egoizmus.

F. Fukuyama v islámskej megalothymii historickú výzvu nevidí: „Navzdory síle, již islám dokazuje svou současnou renesancí, zưstává skutečností, že jde o náboženství prakticky bez jakéhokoli dopadu mimo oblasti, které kulturně spadaji do sféry jeho vlivu." ${ }^{20}$ Preto jeho možnú expanziu považuje za iluzórnu. Islámsky fundamentalizmus pripodobňuje k fašizmu, ktorý „představuje patologický a výjimečný stav". ${ }^{21}$ Všetky silné štáty sú slabé, pretože v sebe obsahujú rozpory a „Váhu má pouze režim nebo systém, jenž přežije celý proces světových dějin"22. Islámsky fundamentalizmus: „Ize chápat jako reakci na neschopnost muslimských společostí obecne udržet si důstojnos tváří v tvář nemuslimskému Západu. ${ }^{23}$ Patologické javy sú len choroby prechodu, každá spoločnost', ktorá nastúpi na cestu industrializácie, môže síce z tejto cesty zíst' (napríklad preto, že kolóna je príliš dlhá a pomalá), poobzerat’ sa po lepšom meste, ale $F$. Fukuyama pravdepodobne predpokladá, že nakoniec dorazí do ciela. Je dokonca možné, že niekde sú alebo vzniknú iné mestá (čo sa dá tvrdiť na základe absencie dôkazov o polohe jednotlivých „povozov“), avšak tieto mestá ostanú obývané, len pokial'ponúknu rovnakú alebo priliehavejšiu paralelu prirodzenej ludskej duše. Tu by bolo možné namietnuṫ, že ak by posledný človek thymotickú zložku potlačil alebo zavrhol, objavili by sa nové rozpory a historické mestá by získali na novej sile. Lepším mestom by mohla byt napríklad thymotická demokracia oproti isothymickej demokracii a megalothymickému autoritatívnemu štátu. Ako by mohol tento štát vyzerat’, naznačujú obaja autori ${ }^{24}$.

\section{Posledný človek}

„Člověk se od zviřat zásadně liší v tom, že ... ještě touží být uznán jako lidská bytost, což znamená, že chce být, uznán', že má hodnotu, která souvisí s ochotou položit život v boji o prestiž"25 F. Fukuyama pracuje s človekom konceptuálnym, nie historickým, verí, že existuje ludská prirodzenost', preto je jeho teória teóriou univerzálneho „človeka ako človeka”. "Člověk nejenže není určen fyzickou nebo zviřrecí přirozeností, ale jeho lidstvi spočivá právě ve schopnosti tuto živočišnou přirozenost překonat nebo popřit..."26 a „lidská svoboda vzniká pouze tehdy, dokáže-li člověk přesáhnout svou přirozenost..." ${ }^{27}$ Nietzscheov posledný človek už (pretože má isothymickou spoločenskou zmluvou "sebaúctu” $v$ zásade vyriešenú”) prahne len po uspokojení túžby (vlastnit”, zažívat', necítit bolest') a rozumu (ktorý nájde spôsob, ako tieto túžby saturovat'). Je zvieratom, „človekom bez hrude". Nie je schopný ohromujúcich výkonov ludského ducha, lebo je bez (lud skej) duše - utilitarizmus a racionalizmus zabija duchovnú híbku, ale aj svedomie, pocity hanby, hlbokého smútku či bolesti, ostáva len prijemná nostalgia, racionálne jednanie, Pahostajný flegmatizmus. Na tomto mieste je vhodné spomenút dôležitý posun vo Fu- kuyamovom myslení, ktorý predstavuje I. T. Budil. Fukuyamov optimizmus sa modifikuje do podoby blízkej „hrozby” zániku Západu. Ak by jeho kniha vyšla dnes v prepracovanom vydaní, pravdepodobne by mohla niest' podtitul Esej o zrode a zániku moderného človeka. Dejiny teda neskončili, pretože hrozí, že nové technológie budú modifikovat samotnú ludskú prirodzenost', „zrušenie človeka” je myslitel'né2 ${ }^{9}$. (S dôležitými implikáciami pre liberálnu demokraciu ako ideálnej projekcie ludskej duše). Každopádne Morlokom je pre F. Fukuyamu „pliživá průměrnost”. F. Fukuyama ale verí, že thymotická spoločnost'je možná, znamená ale nachádzanie spoločného jazyka „dobra a zla”, skupinová súdržnost’ bude musiet’ byt’ založená na istej iracionalite, sebaúcta bude musiet byt’ spojená s úspechom, bude potrebné zamedzit nude, ktorá vyvoláva vášne, viest’ symbolické boje so symbolickými vítazstvami, nájst' ciel'v mieri, v ktorom ale ideály musia mat význam. „Stabilní demokracie vyžaduje zčásti iracionální demokratickou kulturu a spontánní občanskou společnost, jež vyrưstá z preliberálních tradic." ${ }^{\prime 30}$

\section{Namiesto záveru}

Ako z toho celého von, je otázka, ktorú sa už dlho snažia vyriešit myslitelia, vedci, temer každý "nezávislý” film sa touto problematikou zaoberá. Je možné, že cesta nebude v presadzovaní hodnôt, lebo:

Činnosti orientované k jistým hodnotám uvolňuji procesy, které působí tak že měni samu škálu hodnot, které je přivodily. Takový pohyb může nastat, když systém základních hodnot nařizuje jisté specifické jednání a když se jeho vyznavači nestaraj o objektivní důsledky tohoto jednání, ale o subjektivní uspokojení s dobře vykonané povinnosti. Nebo když se jednání v souladu s dominantním souborem hodnot zpravidla soustředuje jen na tuto konkrétní hodnotovou oblast. Ve složité interakci, která utvář společnost, se ale jednání rozvětvuje. Jeho důsledky nejsou omezeny na onu specifickou oblast, v níž se mají soustředit, a objevují se ve vzájemně souvisejících oblastech, jež byly v době jednání jednoznačně ignorovány. Avšak právě díky faktické vzájemné souvislosti těchto oblastí mají dalši důsledky v priléhavých oblastech tendenci působit na systém základních hodnot. Toto zpravidla nečekané pưsobení tvoří nanejvýš důležitou součást procesu sekularizace, transformace nebo zhroucení základních hodnotových systémů. V tom spočivá neodmyslitelný paradox sociálního jednání - „realizace” hodnot může vést $k$ jejich opuštění. Můžeme parafrázovat Goethea a říci: „Die Kraft, die stets das Gute will, und stets das Böse schafft. ${ }^{\square}$

Je možné, že každá vyhranenost', každé principiálne naliehanie vedie napokon k totalite, ktorá niči myšlienku v zárodku. Spoločenská zmena je možná, len ak je pomalá a postupná. Kritika má zmysel, len ak prináša produktívnu alternatívu. Možno by sa dal autoritársky pán zmenit na učitela a otrok na žiaka a ich príbeh prerozprávat'. Je nepochybné, že nás spájajú súbory hodnôt, ktoré sú nám bližšie ako tie inè. Asi by sme sa nemali snažit’nezlučitel'né hodnoty prijímat', liberálny multikulturalizmus je 
preto mýtus, lebo systém musí byt' systémom, aby fungoval. Rovnako nie je možné naliehat na „kultúry", aby sa asimilovali ako také a rozkladat’ organizačné štruktúry s dôsledkami, ktoré nedokážeme vyriešit'. Je však možné, že dokážeme žit vedla seba, ponúkat podla nás lepšiu možnost' a postupne zachytávat' odpadlíkov. Tých však musíme prijat a integrovat', pretože neúspešná integrácia jednotlivcov spôsobuje d’alšie dôsledky mimo rámec našej kontroly. Po masových návratoch „stratených synov” tretej generácie pristảahovalcov do parižskych predmestí sa hovorí o „nerozpustitelnosti islámu”. Stále častejšie však zaznievajú aj otázky, kto toto nerozložitel'né zrážanie sa spôsobuje. Odpoved možno bude v príkazoch a zákazoch, niekde mimo dobra a zla. Imigráciu je vhodné obmedzit', nie však zakázat', konzumná spoločnost’ sa musí zmenit', avšak len postupne. Problémy sa musia riešit', nie však vyhostením ani genocídou. Nebezpečenstvo útokov zvonka síce existuje, islámov je však mnoho. Ak budeme islámy esencializovat’ do hrozby možno si nepriatela nakoniec vytvoríme. Hoci niečo na "prebudenie" táto spoločnos potrebuje, nemusí to byṫ nevyhnutne "poznatel'ný" nepriatel' na spôsob nacionalizmov ktoré sa vzájomne vytvárajú hladaním antitéz. Je až zarážajúce, ako sa na seba vlastne ponášajú. Je možné, že pokial' si konkrétneho nepriatela budeme schopní predstavit’, začneme sa voči nemu vymedzovat', nakoniec sa nám ho podarí vytvorit’ a budeme sa na neho podobat'. Imaginácia je schopná vytvárania takých zrkadlových obrazov.

Hrdinstvo je síce potrebné, ale nemusí nevyhnutne znamenat' ochotu položit život v boji. Hrdinstvo je aj pozriet' sa smrti do tváre, balansovat nad priepastou, ale neprepadnút sa do nej. Strach pred zánikom ani rozum by nás nemal viest’ k bezhlavému a už vôbec nie nekompromisnému jednaniu. Descartova slávna veta by sa dala pretransformovat’ do podoby: Myslím, že zomriem, teda som otrok (svojho strachu).

Vojna a totalita vyvoláva antitézu v podobe "ostrovčekov" slobody, "nous n'avons jamais été aussi libres que sous I'Occupation", povedal Sartre. Podstatne tažšia je ale cesta ku slobode $v$ relatívnom mieri. $\mathrm{Na}$ jednej strane môže byt’ schopnost morálnej vol'by alebo sloboda pohybu, na strane druhej sloboda vybrat’ si z ponúkaných možností. Aby sme si mohli vybrat', musíme poznat povahu týchto volieb, možne dôsledky, ale aj vlastnú motiváciu. Poznávanie seba, vlastných zlyhaní a vášní, ktoré nás ovládajú, vyžaduje nekompromisnejší boj. Druhí sú všade okolo nás a čakajú na naše lokálne nízkoprahové hrdinstvá aj na pána, ktorý sa k nim zniži, a svoju múdrost na ich situáciu aplikuje.

Je otázne, či je krest’anstvo otrocká filozofia. Odvaha nevyhýbat’ sa bolesti ani smrti, schopnost' pochopit a odpustit nepriatelovi, ale aj spravodlivého hnevu schopnost' prekonat' pudový strach a obetovat' sa, schopnost' oprostit sa od tela v zmysle askézy a prechádzat' bolestivou cestou pochybností, pripustit' k sebe dieta a nehádzat' kamene, je možno cesta $\mathrm{k}$ thymotickej spoločnosti, ktorú nám ponúka naša vlastná kultúra.

Dejiny nám určite ponúkajú mnoho príkladov na poučenie. Dejiny však reálne neexistujú, vytvárame si ich, vždy predkladáme náš obraz. Pokial' začneme konat' z reflexie nášho stavu $v$ dejinách, hrozí nám, že sa staneme jednajúcimi výtvormi našich vlastných koncepcii, ako to v minulom storočí dokázalo mnoho vizií sveta, napríklad aj tá realistická.

Bezbrehý relativizmus rovnako ako radikálne zastávanie hodnôt môžu ludskost’ sploštit'. Rovnako ako vyhranené odmietanie esencializovaných postštrukturaliz mov, postmodernizmov, radikálnych konštruktivizmov a dekonštrukcií. Otázka je, či by sme, ako hovorí spoločenskovedné klišé, nemali prestat' vylievat' vaničky aj s diet’atom. To, čo je naozaj treba zachránit', je „tančící hvězda”. Dôstojnost' je dôležitá, pokial' sa ešte dokážeme zasmiat’ sa, pochopit’ a povzniest’ sa.

Dejiny asi neskončili, medzi nami je mnoho pliživých conquíst, proti ktorým môžeme bojovat' a popri tom vytvárat' tancujúce hviezdy. Za jednou z nich stojí naprík lad trh. Alebo aj bezbrehý relativizmus, či rôzne barličky pre pokojný a nenudný život od antidepresív po vízie materializujúcich sa hrozieb. Napokon je otázne, či je niekde „out there" "človek ako človek", ludská bytost’ je komplexný a fascinujúci tvor ako celok s banálnostou zvierata aj vznešenostou hrdinu, dietatom, umelcom aj nekompromisným zástancom princípov.

\section{Literatúra:}

BUDIL, Ivo T.: 2007. Zakladatelé Západu a poslední člověk. Esej o zdrodu a zániku západni civilizace. Ústi nad Labem: Dryad

FUKUYAMA, Francis: 2002. Konec dĕjin a posledni člověk. Praha: Rybka Publishers.

MERTON, Robert K.: 2007. Studie ze sociologické teorie. Praha: SLON.

(Endnotes)

1) Budil, 2007: 8; Fukuyama, 2002:7.

2) Budil, 2007: $9-39$.

3) Fukuyama, 2002: 310. Uvedený citát je reflexia Kojèvovych interpretácií. Kojève sám je však s koncom dejín a psoledným človekom zmierený, vid'. Fukuyama, 2002: 295

4) F. Fukuyama ani I. T. Budil nevidia v11. septembrivyhlásenie vojny, ani prejav stretu civilizácií, vid". Fukyuamovo vyjadrenie, ktoré zverejnil mesiac po útokoch, 2002: 7- 9 a Budil, 2007: 161-164

5) Fukuyama, 2002: 11

6) F. Fukuyama pracuje s konceptom ludskej prirodzenosti, esenciálnej ludskosti, človekom ako takým. 7) Podla Platóna je ideálny politický systém reflexiou ludskej duše, uspokujuje všetky jej tri zložky: túžbu (po veciach mimo subjektu), rozum (prostriedok, ako tieto veci zabezpečit') a "sebaúctu” alebo vznetli8) Vid'. Budil, 2007: 49. Makrohistória je „snaha vysvětlit vznik, rozvoj a pád velkých civilizací a zařadit je do širšiho kontextu svêtových dĕjin."

9) Budil, 2007: 55 .

10) vid.' Budil, 2007: 61-71. 
17) Zarathuštra hovorí: „Je čas, aby si člověk vytkl svưj cill."

8) Vid. Vicovu ludskú autoritu, ktorà je „založena na dověre k lidem zkušenym, kteři jsou jedinečnè rozvážni v jednáni a skvěle moudří ve věcech myšleni." Citované v Budil, 2007: 23.

19) Budil, 2007: 29

20) Fukuyama, 2002: 62

21) Fukuyama, 2002: 137

22) Fukuyama, 2002: 143

23) Fukuyama, 2002: 230

24) Taká spoločnost by pravdepodobne musela prekonat regionálnu úroveň (ale zachovat' si alebo sa pokúby a skupinovú súdržnost), najst spoločne smerovanie, spoločnú hodnotu (napriklad slobodu), dokázala aj duchovne.

25) Fukuyama, 2002: 15

26) Fukuyama, 2002: 155

27) Fukuyama, 2002: 15

28) Vid'. Budil, 2007: $30-31$

29) Fukuyama, 2002: 315

30) Merton, 2007: 128 - 129

\title{
The Cambridge Companion to the Scottish Enlightenment
}

\author{
BROADIE A. (ED.) (2005): Cambridge, Cambridge University Press, $366 \mathrm{~s}$.
}

Recenzovaný sborník The Cambridge Companion to the Scottish Enlightenment predstavuje práce současných renomovaných autorů z různých zemí světa věnujících se problematice skotského osvícenství. Klíčovým postojem, který je zároveň stmelujicím prvkem jednotlivých příspěvků a východiskem pro praktické uspořádání sborníku, je chápán skotského osvícenství jako svébytné národní formy v rámci širokého osvícenského hnutí probíhajícího v osmnáctém století v Evropě a posléze ve Spojených státech amerických. Jednotlivé statě se na pozadí dobového kontextu snaži dobrat specifického charakteru skotského osvícenství a jeho celospolečenského vlivu, což je podle mého názoru nejvlastnějším a nejcennějším přinosem tohoto sborníku.

Právě toto nazírání na osvícenství ne jako na jednolitý blok problémů dané doby s jejich univerzálním řešením je významným posunem v chápání tohoto dějinného období. Nutno připustit, že toto pojetí zřejmě všeobecně ve vyšší míre představuje novum pro českou veřejnost závislou mnohdy na nečetné původní a překladové produkci k tomuto tématu, než tomu může být např v anglosaském světě, kde lze asi od osmdesátých let dvacátého století sledovat směřování od zevšeobecňování historických procesů k důrazu na mnohostrannou kulturně-sociální podmíněnost časově, místně a okolnostně vymezené individuální situace. Tento postoj například zásadně obhajuje Jeremy Black ve své knize Evropa osmnáctého stoletíz roku 1990, která vyšla v českém překladu $v$ roce 2003: Kosmopolitní charakter republiky vzdělanců a podobnost metafor jako lumiére a osvícenství vedl tehdejši i dnešní komentátory k přecenění úlohy společných 
znaků a nedocenění významu různých národních rysů a myšlenkových tradic. $V$ podstatě je právě ona rozmanitost myšlení osmnáctého věku tak zajímavá. Lidé si kladli rưzné otázky, využivali odlišné postupy a docházeli k různým odpovědím." (BLACK, Samuel, 2003, s. 253) Lze tu jistě vysledovat spojitost se současným trendem v historiografii, který je charakterizován nástupem disciplín jako jsou sociální dějiny, mikrohistorie či historická antropologie, a to právě v 80 . letech 20. století.

Zejména pro českého uživatele zabývajíciho se problematikou skotského osvícenství tak recenzovaný sborník predstavuje ucelený zdroj informací a (oproti monografiím jako např. The Scottish Nation. 1700 - 2000 T. M. Devina nebo Capital of the Mind. How Edinburgh Changed the World Jamese Buchana) různorodých pohledů na danou problematiku v jednom svazku, a to na základě současné, aktuální metodologie. Představuje nejenom protipól drívějšímu chápání, ale zároveň otevírá cestu k novým, dřive opomíjeným oblastem badatelského zájmu. Vždyt dosavadní tituly dostupné na českém knižním trhu v naprosté většině (až na ty nejsoučasnější jako např. Kultura a ži vot v raném novověku III. Náboženství, magie a osvícenství Richarda Van Dälmena a výjimky typu výše zmíněného titulu Jeremy Blacka a do jisté míry titulu Evropa a osvicenství Ulricha im Hofa) zastávají právě ono dřivější, zevšeobecňujicí hledisko, v případě starších českých publikací jako Osvicenství - věk rozumu Jana Halady navíc tendenčně zabarvené, poplatné ideologii své doby a protknuté socialistickou rétorikou. Tato tradiční díla upínají pozornost především $\mathrm{k}$ francouzskému osvícenství, které se tak stává až synonymem osvícenství vưbec, a dalším národním podobám osvícenství věnuji omezenou pozornost. Co se týče skotského osvícenství, to, ačkoli pojem „Scottish Enlightenment" byl ustanoven již v roce 1900, je dlouho, prakticky až do současnosti, prezentováno jako součást anglického, poprípadě britského osvícenství, a redukováno na analýzu názorů a děl několika málo skotských autorů, zejména Davida Huma a Adama Smithe v mnohem menší míre pak též Francise Hutchesona a Thomase Reida, přičemž zcela okrajově, většinou pouhým výčtem, jsou zmiňováni dalši představitelé skotského osvícenství, což je príklad i takového díla jako Novověká filosofie. II. Od Newtona po Rousseava Wolfganga Röda, kterému ovšem kromě nejobsáhlejšího výčtu jmen nelze upř́t rovněž cenné srovnání Reida s Humem a Reida s Kantem.

Sbornik The Cambridge Companion to the Scottish Enlightenment splácí v tomto směru letitý dluh skotskému osvícenství, když věnuje prostor hledání jeho specifického místa v kontextu evropského a světového dění v 18 . století a analýze jeho názorové základny, která rozhodujícím způsobem přispěla ke vzniknu věd o člověku, a přinesla zásadní díla, k nimž se podnes obracejí odborníci pro nalézání souvislostí a inspirace.

Součástí sborníku jsou chronologický přehled událostí vztahujících se k skotskému osvícenství, stručná profesní vizitka jednotlivých přispěvovatelů, soupis vybrané bibliografie a zasvěcený úvod, jehož autorem (stejně tak jako dvou dalších příspěvků) je editor sborníku Alexander Broadie, profesor logiky a rétoriky na University of Glasgow a člen Královské společnosti v Edinburghu. Celkem sedmnáct přispěvků sborníku je promyšleně tematicky řazeno tak, aby se jich vždy několik, z různých pozic, věnovalo úžeji vymezené oblasti zájmu a vytvářelo tak její plastičtější obraz, přičemž je zároveň uplatněno chronologické hledisko. Nejdřive je v první sérii přispěvků diskutována otázka kontextu vzniku skotského osvícenství, jeho "předosvícenského podhoubi", a v závěrečných dvou sérích otázka recepce názorů skotských osvícenců a jejich vlivu na myšlenkové procesy i politické postoje $v$ Evropě a Americe, s následným zhodnocením podoby skotského osvícenství v jeho vrcholné fázi, v první polovině devatenáctého století. Příspěvky uvnitř tohoto rámce pak hodnotí a interpretují (s akcentem na povahu lidské mysli a lidské přirozenosti, na sociálnost a socializaci lidské společnosti) prínos skotských osvícencủ k řešení otázek morální filozofie, jejich podíl na rozvoji politické, ekonomické a právní teorie, teorie státu a historiografie a na položení základů k oborům jako jsou antropologie a sociologie.

Při četbě jednotlivých př́spěvků dospiváme k zajímavému poznatku: ne jenom že osvícenské hnutí jako takové nepředstavuje jednolitý názorový blok, jednolitým názorovým blokem není ani samotné skotské osvícenství. Naopak, i to se (při zachován svých charakteristických rysů odlišujících ho od ostatních národních osvícenství) vyznačuje pluralitou postojů, koexistujicích bud' vedle sebe ve vzácně inspirujicí symbióze, nebo střídajících se v závislosti na daných kulturně společenských okolnostech a stávající úrovni lidského vědění v tom kterém stádiu skotského osvícenství. Názorovou rozdílností se zaobírá soustředěně napríklad Luigi Turco ve své stati Moral Sense and the Foundation of Morals, v niž si klade za cíl ukázat morální teorie Francise Hutchesona, Davida Huma a Adama Smithe jako soupeřící systémy a posléze je konfrontovat s kritickým postojem Thomase Reida vưči nim. Podobně Knud Haakonssen ve stati Natural jurisprudence of the theory of justice si všímá názorového vývoje od Francise Hutchesona ve 20. letech 18. století po Dugalda Stewarta o století později, kdy se na pozadí postoje dvou věkově a názorově odlišných skupin skotských myslitelů (Francis Hutcheson, David Hume a Adam Smith vs. Thomas Reid, James Oswald, James Beattie a Dugald Stewart) k otázce po smyslovém či rozumovém pưvodu morálnosti věnuje dobovému pohledu na problém, zda potřeba spravedlnosti je či není vrozenou, neodmyslitelnou součástílidské přirozenosti. I v dalších přispěvcích sledujeme, jak byly názory představitelů prvního období postupně doplňovány, a i prekonávány, aniž by přitom jednotliví myslitelé pouštěl ze zřetelu oblasti zájmu určené konkrétní skotskou skutečností a zkušeností. Ty hrály jak si všímají predevším, nikoli však výhradně, statě z první série, zabývající se identifikací osvícenského podhoubí, v skotském osvícenství stěžejní roli.

Směrování skotského osvícenství totiž vyplynulo z tehdejší skotské reality a bylo, na rozdíl od ostatních zemí, podmíněno zápasem o zachování Skotska jakožto svébytného národního útvaru. Francis Hutcheson, David Hume, John Millar, Adam Ferguson, William Robertson, Adam Smith, Thomas Reid a mnozí další totiž reagovali na to, co bylo v popředí zájmu celé skotské společnosti začátku osmnáctého století, jež se po přijetí tzv. parlamentni unies Anglii (The Union of the Parliaments) v roce 1707 ocitla 
na dějinné křižovatce. Skotové si kladli existenční otázku: Jak zaostalé a stagnujicí Skotsko přežije a jak se bude moci úspěšně rozvíjet v podmínkách vzniklé unie s novým kom plexem vztahů, aniž by ztratilo svobodu a stalo se hospodářským vazalem anglické dynamické ekonomiky představující světovou špičku? Neméně podstatnou otázkou bylo, zda v novém, dravém systému nebude muset skotská společnost upustit od svých tradičních morálních hodnot a společenské soudržnosti.

Zejména v druhé polovině osmnáctého století pak tehdejší britská společnost cítila rovněž potřebu pochopit, popsat a ustanovit vztah mezi jednotlivými vrstvami obyvatelstva, které díky změněným společensko-hospodářským podmínkám vstupovaly do nových vzájemných vztahů. Odtud pramení zvýšená intenzita vypracováváni ekonomických, politických, právních a sociálních teorií. Na konci osmnáctého a začátku devatenáctého století dostupné teoretické zdroje, jako např. Bohatství národů (Wealth of Nations) Adama Smithe z roku 1776, neodpovídaly již dobře aktuální situaci a myslitelé 1. poloviny 19. století byli nuceni formulovat zákonitosti společensko hospodáŕských vztahů nově, v souladu s nově vzniklými potřebami.

$\mathrm{K}$ tomu, že to, co činí skotské osvícenství svébytným, je právě př́tomnos skotské reality v dílech skotských osvíceneckých autorů, se ve svém Úvodu vyjadřuje i Alexander Broadie. Řečeno jeho slovy, ačkoli jsou Skotové otevřeni myšlenkám zvenči, mimo území Skotska, diskutují-li o politice, ekonomice, sociálních strukturách, vzdělávání, právu a náboženství, diskutují o nich v dimenzích národního kontextu a pod vlivem tři specificky skotských institucí: Skotské církve, tedy Kirk, právního systému a univerzit, a to tím spiše, a to je dalším skotským specifikem, že ve velké míre na význačných postech spoluurčují jejich běh. Důležitou roli těchto institucí uznává a do jisté míry kořeny skotského osvícenství spatřuje v nábožensko-politicko-ekonomickém kontextu i Roger Emerson ve svém přispěvku The Context of the Scottish Enlightenment. Za dalši faktor prioritního významu považuje geografické podmínky, což může některým odborníkům připadat jako překvapivé nebo překonané stanovisko. Nicméně, v Emersonově pojetí geografie Skotska s dlouhým pobřežím učinila ze Skotů mořeplavce a krátké, špatně splavné a k v nitrozemské přepravě nevhodné řeky společně se zdrojem nerostných surovin $v$ nedostatečné blízkosti populačních center později, v první čtvrtině devatenáctého století, přispěly ke skonstruování parního stroje. Povětšině neúrodna půda ovlivnila i charakter hospodářství (zkvalitňování půdy, textilní výroba, výroba bělidel a barviv), a demografický profil. Vedla k chudobě a vysoké emigraci, v prípadě zejména obyvatel Highlands a Borders do vojenských služeb, a obyvatel Lowlands za řemeslem, čímž se zvýšil zájem o zejména odborné vzdělávání. Na prahu osvícenství tak Skotové již chápali, že prosperitu země ovlivňuje vzdělanost, zefektivnění výroby a uplatnění vědy.

Co se týče náboženského kontextu, žádný z přispěvkư ve sborníku se bohu žel nezabývá prímo otázkou, zda a do jaké míry se kalvinismus jakožto skotské státn náboženství podílel na utváření specifičnosti skotského osvícenství a na nebývalém hospodářském rozkvětu Skotska mezi lety 1760 až zhruba 1815 svým apelem na praktičnost a postulováním práce jako křestanské povinnosti („„radostná práce na vinic Páně"), které, jak se domnívaji někteří badatelé, mezi nimi např. Ulrich im Hof v práci Evropa a osvícenství, ve svých důsledcích vedlo v 18 . století k většímu rozkvětu a bohatství právě protestantských, a ne katolických zemích. (HOF im, Ulrich, 2001, s. 161) Na s. 145 své knihy Im Hof dále uvádí: „Protestantským církvím jako takovým nechyběly určité předpoklady pro přejímání osvícenských myšlenek. Četba bible podporovala racionální vzdělání, veřící byli zvyklí interpretovat text pomocí filologických prostředkن̉, a to vše bylo pro laiky př́nosem. (...) Pocit kolegiality při spravování Boží církve mohl být prínosem." (HOF im, Ulrich, 2001, s. 145) Na osobní morální čistotu každého jednotlivce, jeho ukázněnost a občanskou zodpovědnost a na společenskou soudržnost bylo nazíráno jako na základní podmínku nezbytnou ke spáse celé komunity (a jistěže i církve jako takové). $Z$ tohoto pohledu měl podle mého názoru požadavek morální čistoty velm praktický a racionální základ. Vztahem víry a racionálna se zabývá přispěvek Religion and Rational Theology, který jeho autor, M. A. Stewart, dělí na podkapitoly nazvané The Early-Eighteenth Century Debate, Hume on Religion a After Hume. Avšak zda se pracovní étos protestantské církve sbližoval s osvícenskou představou povinnosti a zodpovědnosti, se ani zde nedovídáme, nebot oblast zájmu je v tomto př́spěvku posunuta jiným směrem. Nicméně, je nepopiratelné, že presbyteriánská společnost kladla důraz na individuální přispění k prosperitě celku, a tato tradice pak určovala základní rysy skotského osvícenství. Z této perspektivy činí morální a společenské zásady kalvinismu z tohoto náboženství intelektuální základnu skotského osvícenství, které hodnotám jako ctnost, osobní zodpovědnost, racionalita, snaha po zdokonalení a praktický užitek připisovalo zásadní význam.

V osmnáctém století dochází v myšlení a jednání skotské presbyteriánské společnosti k odklonu od původně hlavní oblasti zájmu, tj. udržení si př́izně Boha. Děje se tak v reakci na změněnou realitu pozemského života, a také v důsledku názorových střetů uvnitř samotné Skotské církve, kde postupně nabývají převahy nové postoje. Ten aspekt kalvinistická tradice, který zdůrazňoval zájem o člověka, kolem roku 1750 umož nil nástup liberálnějších postojư uvnitř Církve, když Umírnění Williama Robertsona, ač žádní radikálové, ale naopak političtí konzervativci, získali převahu nad v té době již oslabeným ortodoxním puritanismem a vnesli do politiky Skotské církve pragmatické praktiky podobné těm ze světské sféry.

Schopnost skotské společnosti 1 . třetiny 18 . století pružně reagovat na změněné společenské podmínky, konkrétně rozpoznat přede všemi rázný vstup nového elementu na politickou scénu, a to obchodu jako hybného faktoru rozvoje hospodářských a společenských vztahů, vyzdvihuje ve své stati The Political Theory of the Scottish Enlightenment Fania Oz-Salzbergerová. Eminentní zájem tehdejšího Skotska o ekonomiku a o chod a formu státu všeobecně chápe správně jako důsledek nelehkého, existenčně podmíněného rozhodnutí obětovat státní samostatnost výhodněǰ̌imu 
členství v britském společenství a soustředěné snahy uchovat si v tomto spojenectvíco nejvice ze své suverenity a národní identity. Odštěpení politické ekonomie z morální filozofie a její ustanovení jakožto praktického nástroje politiky postaveného na vědeckých, newtonovských základech považuje Oz-Salzbergerová za nejzásadnější skotský počin a průlomovou alternativu aristotelskému pojetí politiky. Nemalé zásluhy na inspirování tohoto procesu připisuje Montesquieuovu Duchu zákonů a za jeho formování Davidu Humovi, Adamu Smithovi, Johnu Millarovi a Adamu Fergusonovi, a všímá si odlišnosti jejich pohledů. Andrew S. Skinner ve svém př́spěvku Economic theory pak tuto řadu rozšiřuje o další jména jako Henry Home, Lord Kames, Francis Hutcheson, a zejména Sir James Stewart, které uvádí v souvislosti s tzv. teorií stádii, tj. ideou neustálého pokroku lidstva od jednoduchosti k dokonalosti, tedy teorií, kterou skotští osvícenšti myslitelé vtiskli podobu řadě oblastí od ekonomie a politiky po historii, sociologii a antropologii. Způsobem, jakým se toho v jednotlivých oblastech jednotliví myslitelé zhos tili, a kontextem, z něhož vycházeli, se zabývaji kromě výše zmíněných, ekonomicky zaměřených př́spěvků Oz-Salzbergerové a Skinnera statě 10 -13: Natural jurisprudence and the theory of justice Knuda Haakonssena, Legal theory Johna W. Cairnse, Sociality and socialisation Christophera J. Berryho, Historiography Murray G. H. Pittocka a čtvtá kapitola sborníku, Anthropology: the 'original' of human nature, Aarona Garretta. Zvláště Garrett na pozadí srovnánís dalšími teoriemi osmnáctého století, které v sobě spojovaly filosofické, historické a antropologické hledisko, jako Gibbonova 'filosofická historie' a 'experimentální filosofie' Lorda Monbodda, a názorů prezentovaných díly osobností jako Montesquieu a Rousseau charakterizuje specifičnost právě skotského přistupu. Považuje tuto 'skotskou směs' filosofické analýzy lidské přirozenosti a 'empirické' analýzy lidských společností, dějin lidstva a přirozeného prostředí za základ, který dal vznik vědám o člověku.

$\checkmark$ pracích o skotském osvícenství se mnohdy setkáváme právě vzhledem k jeho výraznému zaměření na 'morální vědy' s jeho určitou zjednodušujici interpretací. Jakoby ve Skotsku 18. století ani neexistoval zájem o prírodní vědy jako matematika, fyzika, astronomie, geologie či biologie. Nesporným kladem sborníku The Cambridge Companion to the Scottish Enlightenment je, že podává celistvý obraz skotského osvícenství, ve všech oblastech bádání, jak v sociálních, tak prírodních vědách. Dokladem toho není zdaleka pouze př́spěvek s přiznačným názvem Science in the Scottish Enlightenment Paula Wooda. Ve sborníku je jednotlivými přispěvovateli soustavně akcentována spojitost skotského osvícenského bádání s vědeckou revolucí proběhnuvší v 17. stolet a jeho zakotvenost v prírodě, s dưrazem na aplikaci metodologických postupů prírod ních věd ve vědách společenských.

Sborník The Cambridge Companion to the Scottish Enlightenment je zdařilým přispěvkem k problematice skotského osvícenství. Podává jeho celkový přehled z nejrůznějšich úhlů pohledu a uvádí na pravou míru určité dosavadní desinterpretace. Otázky týkající se role a místa člověka ve společnosti a vztahu společnosti k jednotlivci kladené skotskými mysliteli jsou dnes stejně aktuální jako v osmnáctém století. Jako takový představuje recenzovaný sborník jak cenný zdroj informací a inspiraci pro od borníky zabývající se problematikou osvícenství, tak podnětnou četbu pro každého běžného čtenáře otevřeného diskusi o podobě současného světa.

BLACK, Jeremy (2003): Evropa osmnáctého století. Praha: Vyšehrad.

HOF, Im Ulrich (2001): Evropa a osvicenství. Praha: Nakladatelství Lidové noviny. 


\section{Šéfredaktor:}

Prof. RNDr. Ivo Budil, Ph.D, CSc. (Katedra antropologických a historických studii FF ZČU)

Odpovědná redaktorka:

PhDr. Helena Hricová

Redakčnírada:

Doc. PhDr. Nikolaj Demjančuk, CSc. (Katedra filozofie FF ZČU)

Doc. PhDr. Marie Fenclová, CSC. (Katedra románských jazykư FF ZČU)

Doc. RNDr. Tomáš Hoskovec, CSc. (Ústav jazykovědy a baltistiky Filozofická fakulta MU)

Prof. PhDr. Josef Kandert, CSc. (Fakulta sociálních věd UK Praha)

Prof. Dr. jur. Rüdiger Kipke (Sozialwissenschaften, Univerzita Siegen, Německo)

Doc. PhDr. Petr Kotátko, CSc. (Filosofický ústav AV ČR)

Doc. PhDr. Martin Kreidl, M.A., Ph.D. (Katedra sociologie, FF ZČU)

.

Prof. PhDr. Evěen Neustupný, CSc. (Filozofická fakulta UK, Praha)

Doc. Vladimir Penčev, Ph.D. (Ústav pro folklor Bulharské akademie věd, Blagoevgrad, Bulharsko)

Prof. John Garrard, Ph.D. (ESPACH, University of Salford, Velká Británie)

Doc. PhDr. Pavel Vařeka, Ph.D. (Katedra archeologie, FF ZČU) 
DO ACT FF ZČU PŘISPĚLI:

Mgr. Petra Burzová

Katedra politologie a mezinárodnich vztahů FF ZČU | burzova@kap.zcu.cz

doc. PhDr. Ladislav Cabada, Ph.D.
Katedra politologie a mezinárodnich vztahů FF ZČU | cabada@kap.zcu.cz

doc. PhDr. Šárka Cabadová Waisová, Ph.D.

作

Mgr. Vladimír Glomb

Ustav Dalneho VychoduFF UK Vladous2000@yahoo.com

Mgr. Svatava Heinlová

Centrum jazykové prípravy zČU | heinlova@cjp.zcu.cz

doc. Pavel Hošek, Th.D.

Evangelická a teologická univerzita UK | pahos.ets@gmail.com

Mgr. Lucie Jirásková

Filozofická fakulty UK | lucie.jiraskova@ff.cuni.cz

PhDr. Jan Lukavec, Ph.D.

Národní knihovny české republiky | Jan.Lukavec@nkp.cz

Bc. Daniel Rafael Moulis

Centrum blizkovýchodních studii, Katedra antropologických a historických věd FF ZČU

david.moulis@email.cz

PhDr. Vlastimil Novák, Dr.

Národni muzeum - Náprstkovo muzeum | num.npm @aconet.cz

PhDr. Lukáš Pecha, Ph.D.

Centrum blízkovýchodnich studii, Katedra antropologických a historických věd FF ZČU Centrum blizkovych
pecha@kbs.zcu.cz

Barbora Polifková

Centrum historických věd, Katedra antropologických a historických věd FF ZČU Barbora.Polifkova@seznam.cz

Mgr. Kateřina Šašková, Th.D.

Centrum historických vĕd, Katedra antropologických a historických věd FF ZČU

katerina.saskova@gmail.com 
4

4

$$
4
$$$$
4
$$

4

4

4

4

Vydává Západočeská Univerzita v PIzni

Ivo T. Budil, editor

Registrace MKČR E 16521

Vychází třikrát ročně.

Grafický design Štěpánka Bláhovcová

Sazba Štẹ̌pánka Bláhovcová
Fotografie na titulunis stranè a na str. 126 Filip Šach

ISSN 1802-0364

4

4
4

4

4

4

4

4

4 
4

4

4

4

4

4

4

4

4

4 


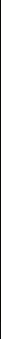

\section{BEROLN}

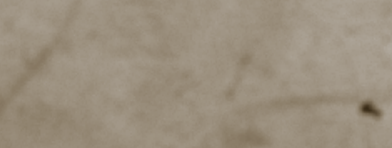
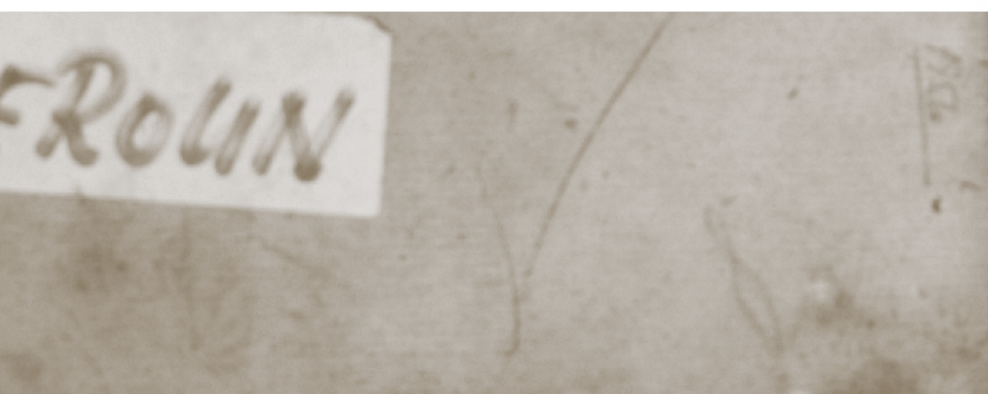

4

Q 